\title{
Children with cryptogenic localization related epilepsy : clinical outcome
}

Citation for published version (APA):

Reijs, R. (2008). Children with cryptogenic localization related epilepsy : clinical outcome. [Doctoral Thesis, Maastricht University]. Datawyse / Universitaire Pers Maastricht. https://doi.org/10.26481/dis.20081113rr

Document status and date:

Published: 01/01/2008

DOI:

10.26481/dis.20081113rr

Document Version:

Publisher's PDF, also known as Version of record

\section{Please check the document version of this publication:}

- A submitted manuscript is the version of the article upon submission and before peer-review. There can be important differences between the submitted version and the official published version of record.

People interested in the research are advised to contact the author for the final version of the publication, or visit the DOI to the publisher's website.

- The final author version and the galley proof are versions of the publication after peer review.

- The final published version features the final layout of the paper including the volume, issue and page numbers.

Link to publication

\footnotetext{
General rights rights.

- You may freely distribute the URL identifying the publication in the public portal. please follow below link for the End User Agreement:

www.umlib.nl/taverne-license

Take down policy

If you believe that this document breaches copyright please contact us at:

repository@maastrichtuniversity.nl

providing details and we will investigate your claim.
}

Copyright and moral rights for the publications made accessible in the public portal are retained by the authors and/or other copyright owners and it is a condition of accessing publications that users recognise and abide by the legal requirements associated with these

- Users may download and print one copy of any publication from the public portal for the purpose of private study or research.

- You may not further distribute the material or use it for any profit-making activity or commercial gain

If the publication is distributed under the terms of Article $25 \mathrm{fa}$ of the Dutch Copyright Act, indicated by the "Taverne" license above, 
Children with cryptogenic localization related epllepsy: clinical outcome 
ISBN 9789052787701

Copyright (C Rianne Reijs, Maastricht 2008

Children with cryptogenic localization related epilepsy: clinical outcome. / Rianne Reijs. Thesis Universiteit Maastricht - with references - with summary in Dutch

Printed by Datawyse, Universitaire Pers Maastricht.

All rights reserved. Illustrations and brief excerpts from this publication may be used for scientific or educational purposes, provided that the source is acknowledged.

Het schilderij op de kaft van dit proefschrift is gemaakt door Gerrie Volckerick,

kunstenaar bij Atelier Galerie Kempro 


\title{
Children with cryptogenic localization related epilepsy: clinical outcome
}

\author{
PROEFSCHRIFT \\ ter verkrijging van de graad van doctor aan de Universiteit Maastricht, \\ op gezag van de Rector Magnificus, Prof. mr. G.P.M.F. Mols \\ volgens het besluit van het College van Decanen, \\ in het openbaar te verdedigen \\ op donderdag 13 november 2008 om 14.00 uur \\ door \\ Rianne Petra Reijs \\ gevolgd door de verdediging van bijbehorend werk \\ door S. van Mil om 15.30 uur dezelfde dag
}

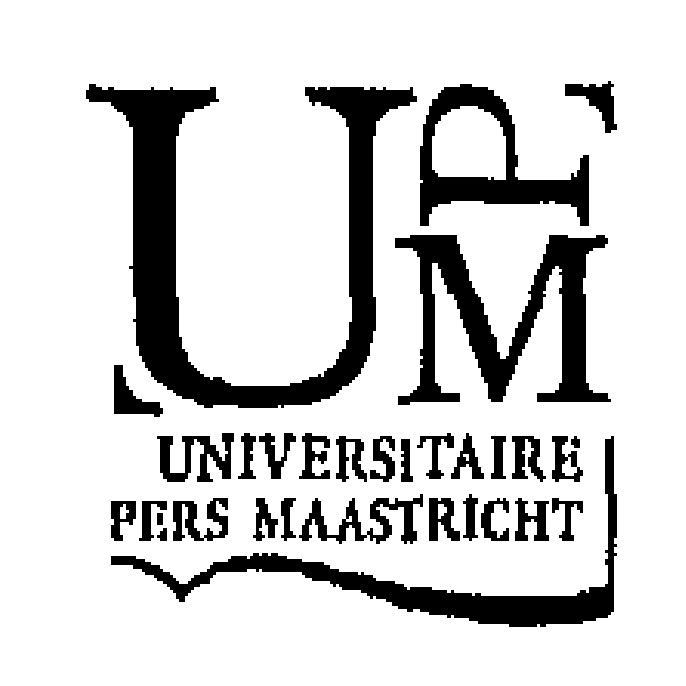




\section{Promotores}

Prof. dr. A.P. Aldenkamp

Prof. dr. W.O. Renier (Radboud Universiteit Nijmegen)

\section{Copromotor}

Dr. J. Arends (Epilepsiecentrum Kempenhaeghe)

\section{Beoordelingscommissie}

Prof. dr. H. Vles (voorzitter)

Prof. dr. G. Baker (University of Liverpool, United Kingdom)

Prof. dr. J. Jolles

Dr. M. de Krom (afdeling Neurologie, academisch ziekenhuis Maastricht)

Prof. dr. M. Sillanpää (University of Turku, Finland) 
How do you know that you're right, if you're not nervous anymore?

(from Bling (Confessions of a King) by Brandon Flowers and Mark Stoermer, from the album Sam's Town, by The Killers (c) 2006) 


\section{Contents}

\section{Chapter One}

Cryptogenic localization-related epilepsy with childhood onset:

The problem of definition and prognosis

\section{Chapter Two}

The validity of a separate classification of cryptogenic localization related epilepsy amongst childhood epilepsies

\section{Chapter Three}

Cryptogenic localization related epilepsy in children from a tertiary outpatient clinic: Is neurological and neuropsychological outcome predictable?

\section{Chapter Four}

A follow up study of cryptogenic localization related epilepsy with childhood onset; neurological and neuropsychological course in a tertiary outpatient clinic

\section{Chapter Five}

Motor function in children with cryptogenic localization related epilepsy

General Discussion

Samenvatting

Persoonlijke noot

Curriculum Vitae

Publications 
Introduction 


\section{Introduction}

Cryptogenic localization related epilepsy (CLRE) is defined as the recurrence of unprovoked seizures (epilepsy) with a localized onset (localization related), with an unknown, or obscure (cryptogenic) etiology. ${ }^{1}$ The severity of CLRE is estimated to be somewhere between the more benign idiopathic epilepsies and the more malign encephalopathies and symptomatic syndromes. ${ }^{2}$

It is assumed that the causes for epilepsy in children with CLRE will be recognized, when imaging techniques and knowledge on etiology develop. Therefore, the population of CLRE is subject to virtually constant change: whenever a new syndrome or cause for epilepsy is described, these children are no longer part of the CLRE population. Possibly because of this temporary nature, not much is known about the course of the epilepsy in CLRE.

However, in the pediatric population, up to one third of children have this diagnosis. For these children and their parents, no clear prognosis can be outlined. Furthermore, no apparent treatment choices can be advised.

It has been long since recognized that epilepsy in childhood has an impact on psychosocial functioning. Most probably the occurrence of the seizures, or the epilepsy as a whole, influence neuropsychological development. There is no reason to suspect that children with CLRE evade this effect, but also in this area there is a lack of knowledge.

With the studies described in this thesis, we aim to describe the cohort of children with CLRE at our epilepsy centre. Furthermore, we study the variables possibly related to the outcome. Outcome in childhood epilepsy is dual: it is a reflection of the seizure frequency, as well as of the comorbidity occurring with the epilepsy mainly focusing on neuropsychological development.

The studies of this thesis were carried out at Kempenhaeghe Epilepsy Centre. Patient data were collected through an ongoing study, making use of a clinical programme. In this programme children were admitted for three days during which a standardized protocol of assessments was carried out. These included neurological investigation and history taking, as well as observation by trained nurses, EEG recordings, neuropsychological testing, psychomotor screening and educational assessment.

The programme is easily accessible for patients from secondary centres. Patients mostly return to the care of their secondary centre physician right after the analyses have finished. Therefore, even though Kempenhaeghe is a tertiary epilepsy clinic, the population seen in this programme is not per se characterized by severe types of epilepsy and are representative for 'the population of children with CLRE'. .

Firstly, we established a more thorough background for our studies, by means of a review of the existing literature, which is presented in Chapter One. 
CLRE is often incorporated with SLRE or IGE in cohort studies, which leads to a lack of evidence directly describing (children with) CLRE. With this in mind, we tested our hypothesis that CLRE differs significantly from SLRE and IGE, which would allow us to further study our cohort. This is described in Chapter Two.

Chapter Three concerns a study of our CLRE cohort. Data describing children with CLRE in our outpatient clinic were analyzed in search of correlations between certain epilepsy related characteristics and other patient related characteristics. Also, the outcome as represented by several epilepsy related and developmental variables was studied.

In Chapter Four a follow up is presented, studying a part of the cohort described in Chapter Three. Again, correlations were studied between epilepsy related variables and the outcome both neurologically and neuropsychologically.

Chapter Five focusses on two aspects of development possibly affected by CLRE: motor development and learning difficulties. As both comorbidities often occur with childhood epilepsy, we studied whether the impact of learning difficulties on motor development might be differentiated from the impact of the epilepsy in CLRE.

Finally, in the General Discussion, the results of all five studies are discussed. A more general conclusion is sought regarding the course of CLRE in childhood and its impact on neuropsychological and motor development.

\section{References}

1 Commission on Classification and Terminology of the International League Against Epilepsy Proposal for revised classification of epilepsies and epileptic syndromes. Epilepsia 1989;30:389-399.

2 Dunn DW, Buelow JM, Austin JK, Shinnar S, Perkins SM. Development of syndrome severity scores for pediatric epilepsy. Epilepsia. 2004 Jun;45(6):661-6. 


\section{Chapter 1}

Cryptogenic localization related epilepsy with childhood onset:

The problem of definition and prognosis 


\begin{abstract}
Up to one third of the children with epilepsy are diagnosed with cryptogenic localization related epilepsy (CLRE). CLRE is a large non-specific category within the ILAE classification. For this population no unequivocal prognosis exists.
\end{abstract}

Methods Twenty-five articles describing aspects of CLRE were included in this review.

Results As a result of the progress in epilepsy research, as well as more advanced investigation in individual cases, the population of CLRE constantly changes. Also, disagreement on interpretation of the classification has resulted in striking differences between the populations described. High remission rates are reported, but relapse occurs frequently, leaving the long-term prognosis unforeseeable. This is reflected in academic and psychosocial prognosis, which is described to be problematic in CLRE specifically.

Possible prognostic factors of CLRE in children have been identified: age at onset, seizure semiology, seizure frequency, intractability, interictal epileptiform activity on $E E G$ and premorbid $I Q$. These factors are explored to define subgroups within the CLRE population.

Discussion Prospective studies on well-defined CLRE cohorts are needed to identify factors that distinguish various prognostic subgroups. Specific attention should be focused on course of the epilepsy, scholastic achievement and psychosocial outcome.

Published as:

Reijs, RP', van Mil, SGM*, van Hall, MHJA, Arends, JBAM, Weber, JW, Renier, WO, \& Aldenkamp, AP (2006).

Cryptogenic localization related epilepsy with childhood onset: The problem of definition and prognosis.

Epilepsy \& Behavior, 8(4): 693-702

both authors accepted as first author. 


\section{Introduction}

Epilepsy is a symptom of an underlying neurological deficit or dysfunction. ${ }^{1}$ However, the exact mechanisms underlying epilepsy remain unknown. Through classification of the epilepsies, results of research can be universally compared. In the field of clinical research, the most widely used classification is the International Classification of Epilepsies and Epileptic Syndromes proposed by the International League Against Epilepsy (ILAE). ${ }^{2}$ According to this classification the cryptogenic epilepsies are presumed to be symptomatic, but their etiology is unknown.

With respect to severity, epilepsies can be subdivided into more benign (idiopathic generalized epilepsies (IGEs) and idiopathic localization related epilepsies (ILREs)) and more malignant (symptomatic localization related epilepsies (SLREs), followed by symptomatic "catastrophic" generalized epilepsies (SGEs)). Cryptogenic localization related epilepsy (CLRE) can be positioned between the idiopathic and the symptomatic epilepsies. Indeed, when scoring the severity of pediatric epilepsy syndromes in the development of the Epileptic Syndrome Severity Scores-Child (ESSS-C), Dunn et al. consulted experts who rated the severity of CLRE as 7 on a 10-point scale. ${ }^{3}$ Benign epilepsy with centrotemporal spikes was rated 2, and Landau-Kleffner syndrome 8 , on this scale.

Although the ILAE classification ${ }^{2}$ has been said to be very applicable, also in the range of childhood epilepsies ${ }^{4-6}$, it has also been strongly criticized. Only a small proportion, 4 to $21 \%{ }^{6}$, of the patients in a tertiary epilepsy center are diagnosed with specific epilepsy syndromes; most patients end up in rather unspecific categories. One of these relatively nonspecific categories is CLRE. Up to one-third of children with epilepsy are classified as having CLRE. ${ }^{7-9}$

In daily practice, accurate classification should lead to information on prognosis as well as preferred treatment and pedagogical and academic support. Prognosis should concentrate not only on seizure outcome, but also on cognitive development and educational achievement. As epilepsy is known to have a large impact on these developmental aspects ${ }^{10}$, a detailed classification is of major importance for children with epilepsy. As far as CLRE is concerned, no unequivocal prognosis is known. ${ }^{11-13}$ In this article, we review the available literature on the prognosis of CLRE with childhood onset. The first issue, which is discussed thoroughly, is the diagnostic reliability of CLRE. Lack of a clear diagnosis makes it impossible to formulate the right prognosis. For this reason, we critically look at the current classification system. As we focus on childhood epilepsies, we approach mainly two aspects of prognosis: seizure control and psychosocial outcome. The psychosocial outcome is the result of cognitive development and academic opportunities. In the neuropsychological literature, this is described in terms of cognitive variables, educational achievements, and behavior. 


\section{Methods}

\section{Study selection}

We searched for articles with WebSPIRS 5.03 for Medline and Pub-Med, using the query: (cryptogenic OR localisation related OR partial) AND epilep* AND child* AND (prognos* OR outcome OR neuropsychol* OR cognit*). An asterisk indicates that the search was extended to find all terms that begin with a given text string. The limits were set for English language, research in humans, and a publication date up to November 2005. One hundred and twelve articles were found.

On the basis of the titles of the publications, we studied the abstracts that seemed to describe the neurological and neuropsychological prognosis of children with CLRE. Many studies did not specify their results as for children with CLRE, but described combinations of either "cryptogenic and/or symptomatic" or "cryptogenic and/or idiopathic" epilepsy. Because we were interested in the prognosis of CLRE, these articles appeared to be inappropriate.

After selecting the relevant articles, we used the PubMed-function related articles. We also checked the references of the selected articles for other relevant literature. Case reports were not considered. In total, 25 articles were included.

\section{Subjects}

The patients described in the included studies have been diagnosed with CLRE. Patients with the diagnosis of localization related epilepsy with cryptogenic etiology, but related to a specific syndrome, were not considered to have CLRE.

Age at onset of epilepsy ranged between 0 and 18. Age at follow-up varied (Table 1). In 15 studies, the patients described were still children at the end of follow-up. ${ }^{14-28}$ One study describes very long term outcome; hence the followed up patients are all adults. ${ }^{29}$ in the other studies, patients were followed into adolescence and adulthood. ${ }^{4,5,7,30-35}$ Therefore, it is fair to say the reviewed studies focused on school-aged children and their prognosis.

Patients described in the studies selected for this review were included because of their epilepsy. In some studies, however, epilepsy patients were selected using more specific criteria, such as seizure freedom ${ }^{14,20,27}$, a normalized $E E G^{14,20}$, language disorders and the refractory nature of their epilepsy ${ }^{26}$, and fluctuations in cognitive performance ${ }^{21}$ (Table 2). It is important that these criteria be taken into account when reviewing these articles, because they may influence the prognosis we attempt to construct. For this purpose, an overview is given in Table 2. 
Table 1. Cohorts described in reviewed articles

\begin{tabular}{|c|c|c|c|c|}
\hline Author, year & Oufcome variable & $\mathrm{n}$ & Age at follow-up & Duration of follow-up \\
\hline $\begin{array}{l}\text { Aldenkamp and Arends, } \\
2004 \text { [21] }\end{array}$ & Educational achievement & $\begin{array}{l}\text { CLRE: } 68 \\
\text { SLRE: } 28 \\
\text { IGE: } 19 \\
\text { Controls: } 31\end{array}$ & $7-12$ years & Not applicable \\
\hline Arts et al., 1999 [25] & Remission & $\begin{array}{l}\text { CLRE: } 86 \\
\text { SLRE: } 69 \\
\text { ILRE: } 28\end{array}$ & Median 5.5 years & 2 years \\
\hline Arts et al., 2004 [19] & Remission & $\begin{array}{l}\text { CLRE : } 86 \\
\text { SLRE : } 67 \\
\text { ILRE : } 28\end{array}$ & Median 5.5 years & 5 years \\
\hline Berg et al., 1999 [4] & Interrater agreement & $\begin{array}{l}\text { CLRE: } 103 \\
\text { Total patients: } 613\end{array}$ & 1 month -15.6 years & Not applicable \\
\hline Berg et al., 2000 [5] & Reassessment & $\begin{array}{l}\text { CLRE: } 103 \\
\text { Total patients: } 613\end{array}$ & 1 month -15.6 years & Median 5.3 years \\
\hline Berg et al., 2001 [31] & $\begin{array}{l}\text { Remission, relapse (reas- } \\
\text { sessment) }\end{array}$ & $\begin{array}{l}\text { CLRE: } 99 \\
\text { SLRE: } 189 \\
\text { ILRE: } 57\end{array}$ & 1 month -15.6 years & Median 5.3 years \\
\hline Berg et al., 2004 [7] & $\begin{array}{l}\text { Remission, relapse, Markov } \\
\text { process }\end{array}$ & $\begin{array}{l}\text { CLRE: } 216 \\
\text { SLRE: } 79 \\
\text { ILRE: } 56\end{array}$ & $7-12$ years & Median 7 years \\
\hline $\begin{array}{l}\text { Camfield and Camfield, } \\
1993 \text { [32] }\end{array}$ & Remission & $\begin{array}{l}\text { CLRE: } 132 \\
\text { Total patients: } 504\end{array}$ & 1 month-16 years & Average 85 months \\
\hline Genton et al., 1997 [33] & $\begin{array}{l}\text { Remission, psycho-social } \\
\text { outcome }\end{array}$ & $\begin{array}{l}\text { CLRE: } 38 \\
\text { SLRE: } 68\end{array}$ & $5-46$ years & 5 to 41 years \\
\hline Geelhoed et al., 2005 [30] & Remission & $\begin{array}{l}\text { CLRE: } 299 \\
\text { SLRE: } 183 \\
\text { ILRE: } 58\end{array}$ & 1 month-16 years & 6 months -26 years \\
\hline Grosso et al., 2005 [17] & Response to topiramate & $\begin{array}{l}\text { CLRE : } 7 \\
\text { SLRE : } 12 \\
\text { ILRE : } 2\end{array}$ & $0-24$ months & Median 11 months \\
\hline Hauser et al, 1996 [34] & Remission & $\begin{array}{l}\text { CLRE: } 19 \\
\text { SLRE: } 43 \\
\text { ILRE: } 26\end{array}$ & $\begin{array}{l}\text { Mean } 9.6 \text { years plus mean } \\
\text { follow-up } 5.3 \text { years }\end{array}$ & Up to 14 years \\
\hline Hoie et al., 2004 [15] & Nonverbal intelligence & $\begin{array}{l}\text { CLRE: } 25 \\
\text { SLRE: } 42 \\
\text { ILRE: } 30 \\
\text { Total: } 198 \\
\text { Controls: } 126\end{array}$ & $6-12$ years & Not applicable \\
\hline Miura, $2004[16]$ & Response to zonisamide & CLRE: 72 & $\begin{array}{l}8.3 \text { years ( } 3 \text { months }-14.11 \\
\text { years) }\end{array}$ & $\begin{array}{l}27.2 \text { months ( } 6-43 \\
\text { months) }\end{array}$ \\
\hline Murakami et al., 1995 [27] & Withdrawal, age, EEG & $\begin{array}{l}\text { CLRE: } 58 \\
\text { SLRE: } 60 \\
\text { ILRE: } 72\end{array}$ & $4-18.2$ years & At least 5 years \\
\hline Ohta et al., 2004 [28] & $\begin{array}{l}\text { Withdrawal, risk factors for } \\
\text { relapse }\end{array}$ & CLRE; 82 & Average 12.4 years & Average 4.7 years \\
\hline
\end{tabular}




\begin{tabular}{|c|c|c|c|c|}
\hline Author, year & Outcome variable & $n$ & Age at follow-up & Duration of follow-up \\
\hline Oostrom et al., 2001 [24] & $\begin{array}{l}\text { Parents' perceptions at } \\
\text { onset }\end{array}$ & $\begin{array}{l}\text { CLRE: } 33 \\
\text { IGE: } 33\end{array}$ & $5-16$ years & Not applicable \\
\hline Oostrom et al., 2002 [23] & Attention & $\begin{array}{l}\text { CLRE: } 23 \\
\text { IGE: } 28 \\
\text { Controls; } 48\end{array}$ & $5-16$ years & 1 year \\
\hline Oostrom et al., 2003 [22] & Behavioral problems & $\begin{array}{l}\text { CLRE: } 33 \\
\text { IGE: } 33 \\
\text { Controls: } 66\end{array}$ & $5-16$ years & 1 year \\
\hline Oostrom et al., 2005 [18] & Cognition and behavior & $\begin{array}{l}\text { CLRE: } 19 \\
\text { ILRE: } 11 \\
\text { IGE: } 12 \\
\text { Controls: } 30\end{array}$ & $7-16$ years & $3-4$ years \\
\hline Parkinson, 2002 [26] & Language disorders & $\begin{array}{l}\text { CLRE: } 16 \\
\text { SLRE: } 37 \\
\text { CGE: } 33 \\
\text { SGE: } 13\end{array}$ & 11.4 years $(5-18.9$ years $)$ & Not applicable \\
\hline Shinnar et al., 1999 [35] & Reclassification, remission & $\begin{array}{l}\text { CLRE: } 34 \\
\text { Total patients: } 182\end{array}$ & $\begin{array}{l}1 \text { month- } 19 \text { years, } \\
\text { plus follow up }>5 \text { years }\end{array}$ & $\begin{array}{l}\text { Mean } 8.2 \text { years, } \\
\text { minimum } 2 \text { years }\end{array}$ \\
\hline Sillanpää et al, 1999 [37] & Remission & $\begin{array}{l}\text { CLRE : } 40 \\
\text { SLRE : } 120 \\
\text { ILRE : } 23\end{array}$ & Mean 35.6 years at last visit & 30 years \\
\hline Verrotti et al., 2000 [14] & Discontinuation of AED & CLRE; 89 & Mean 11.2 years (SD 3.4 ) & $5.1-6.7$ years \\
\hline Verrotti et al., 2000 [20] & Withdrawal, predictive EEG & CLRE: 84 & Mean 10.6 years $(\mathrm{SD} 3.0$ ) & $\begin{array}{l}4-7 \text { years } \\
\text { mean } 5.5 y\end{array}$ \\
\hline
\end{tabular}

a CLRE, cryptogenic localization related epilepsy; SLRE, symptomatic localization related epilepsy; 1GE, idiopathic generalized epilepsy; CGE, cryptogenic generalized epilepsy; SGE, symptomatic generalized epilepsy; AED, antiepileptic drugs

\section{Studies}

Only three articles focused purely on children with CLRE. ${ }^{14,20,28}$ in the other studies, the authors provided specific results for or made remarks on the patients with CLRE within their pediatric epilepsy cohort.

Most studies follow the 1989 ILAE proposal for classification of epileptic seizures and epilepsy syndromes. ${ }^{2}$ However, this classification leaves room for interpretation. The Commission on Classification and Terminology defines symptomatic epilepsies and syndromes as the consequence of a known or suspected disorder of the central nervous system. The cryptogenic category is derived from this definition: cryptogenic epilepsies are presumed to be symptomatic but the etiology is unknown. Subsequently, the classification is not decisive on a matter such as mental retardation. To some authors, the presence of mental retardation is considered grounds for a diagnosis of (remote) SLRE ${ }^{19,25,28,29,32,34}$ or for exclusion from a study of patients with CLRE $^{14,20}$ (Table 2). However, the majority of authors do not mention this issue. ${ }^{4,5,7,15-18,21-24,26,27,30,31,33,35}$ Importantly, intelligence has been shown to be a prognostic factor with respect to both seizure outcome and neuropsychological outcome. 
Table 2. Characteristics of reviewed articles

\begin{tabular}{|c|c|c|c|c|c|}
\hline Author, year & Definition of CLREa & Neuroimaging & $1 \mathrm{Q}<70^{\mathrm{b}}$ & $\begin{array}{l}\text { Prospectivel } \\
\text { retrospective }\end{array}$ & Complicating factors \\
\hline $\begin{array}{l}\text { Aldenkamp and } \\
\text { Arends, } 2004 \text { [21] }\end{array}$ & - & Not mentioned & - & Prospective & $\begin{array}{l}\text { Fluctuations in cognitive } \\
\text { performance; clinical } \\
\text { question on cognitive } \\
\text { impact of discharges }\end{array}$ \\
\hline $\begin{array}{l}\text { Arts et al., } 1999 \\
{[25], 2004 \text { [19] }}\end{array}$ & ILAE [1] & $\begin{array}{l}\text { Not in absence epilepsy; } \\
\text { not when treating physician } \\
\text { did not find it necessary. }\end{array}$ & SLRE & Prospective & \\
\hline $\begin{array}{l}\text { Berg et al., } 1999 \\
{[4], 2000[5], 2001 \mathrm{i}} \\
{[31]}\end{array}$ & $\begin{array}{l}\text { No identifiable underly- } \\
\text { ing etiology, no idio- } \\
\text { pathic syndrome; focus } \\
\text { on EEG: SLRE }\end{array}$ & $\begin{array}{l}\text { Neuroimaging was done in - } \\
79.6 \% \text { of children }\end{array}$ & & Prospective & $\begin{array}{l}\text { Symptomatic epilepsy } \\
\text { diagnosed on basis of } \\
\text { localization, with crypto- } \\
\text { genic etiology }\end{array}$ \\
\hline $\begin{array}{l}\text { Berg et al., } 2004 \\
{[7]}\end{array}$ & $\begin{array}{l}\text { Symptomatic vs crypto- } \\
\text { genic based on aetiology }\end{array}$ & $\begin{array}{l}\text { See Berg, } 1999 \\
y\end{array}$ & - & Prospective & \\
\hline $\begin{array}{l}\text { Camfield and } \\
\text { Camfield, } 1993 \\
{[32]}\end{array}$ & - & $\begin{array}{l}\text { All CLRE patients had } \\
\text { normal CT }\end{array}$ & $\begin{array}{l}\text { CLRE defined as } \\
\text { 'otherwise } \\
\text { normal children' }\end{array}$ & Prospective & \\
\hline $\begin{array}{l}\text { Genton et al., } \\
1997[33]\end{array}$ & $\begin{array}{l}\text { Without evidence of a } \\
\text { brain lesion, no idio- } \\
\text { pathic focal epilepsy }\end{array}$ & $\begin{array}{l}\text { Neuroimaging was done in - } \\
15 \text { out of } 38 \text { patients with } \\
\text { CLRE }\end{array}$ & & Retrospective & \\
\hline $\begin{array}{l}\text { Geelhoed et al., } \\
2005[30]\end{array}$ & ILAE [1] & - & - & Retrospective & \\
\hline Grosso, 2005 [17] & & $\begin{array}{l}\text { MRI was done in all } \\
\text { patients }\end{array}$ & - & Prospective & \\
\hline $\begin{array}{l}\text { Hauser et al., } \\
1996[34]\end{array}$ & $\begin{array}{l}\text { Symptomatic and of } \\
\text { unknown etiology }\end{array}$ & $\begin{array}{l}\text { Neuroimaging was done in } \\
\text { all patients with CLRE }\end{array}$ & $\begin{array}{l}\text { Symptomatic } \\
\text { aetiology }\end{array}$ & Prospective & \\
\hline $\begin{array}{l}\text { Hoie ef al., } 2004 \\
{[15]}\end{array}$ & $\operatorname{ILAE}[1]$ & $\begin{array}{l}\text { Neuroimaging was done in } \\
192 \text { of } 198 \text { patients }\end{array}$ & & Prospective & $\begin{array}{l}\text { Unexplained adaptation of } \\
\text { the ILAE guidelines }\end{array}$ \\
\hline Miura, 2004 [16] & - & Not mentioned & - & Prospective & \\
\hline $\begin{array}{l}\text { Murakami et al., } \\
1995[27]\end{array}$ & ILAE [1] & Not mentioned & - & Retrospective & \\
\hline $\begin{array}{l}\text { Ohta et al., } 2004 \\
\text { [28] }\end{array}$ & $\begin{array}{l}\text { Not idiopathic or } \\
\text { symptomatic; no } \\
\text { underlying diseases, no } \\
\text { signs/symptoms of brain } \\
\text { injuries }\end{array}$ & $\begin{array}{l}\text { Definition of CLRE } \\
\text { suggests that all included } \\
\text { patients did have (normal) } \\
\text { MRI }\end{array}$ & SLRE & Prospective & $\begin{array}{l}3 \text { years of seizure freedom, } \\
\text { no epileptic discharges on } \\
\text { EEG }\end{array}$ \\
\hline $\begin{array}{l}\text { Oostrom et al., } \\
2001[24], 2002 \\
{[23], 2003[22]_{1}} \\
2005[18]\end{array}$ & $\begin{array}{l}\text { Probably of symptomatic } \\
\text { origin but no etiology } \\
\text { has been found. }\end{array}$ & $\begin{array}{l}\text { cNeuroimaging was normal } \\
\text { in all patients with CLRE }\end{array}$ & & prospective & \\
\hline $\begin{array}{l}\text { Parkinson, } 2002 \\
\text { [26] }\end{array}$ & - & $\begin{array}{l}\text { In collaboration with the } \\
\text { referring consultant }\end{array}$ & - & Prospective & $\begin{array}{l}\text { Refractory epilepsy; more } \\
\text { than Iwo-thirds attend } \\
\text { special education; lan- } \\
\text { guage impairments }\end{array}$ \\
\hline $\begin{array}{l}\text { Shinnar et al., } \\
1999 \text { [35] }\end{array}$ & $\operatorname{ILAE}[1]$ & $\begin{array}{l}\text { CT or MRI was performed } \\
\text { when clinically indicated }\end{array}$ & 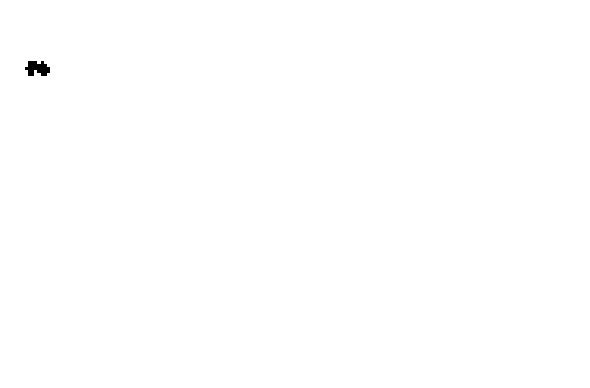 & Prospective & $\begin{array}{l}\text { Symptomatic epilepsy } \\
\text { diagnosed on basis of } \\
\text { localization }\end{array}$ \\
\hline
\end{tabular}




\begin{tabular}{|c|c|c|c|c|c|}
\hline Author, year & Definition of CLREa & Neuroimaging & $Q Q<70^{b}$ & $\begin{array}{l}\text { Prospectivel } \\
\text { retrospective }\end{array}$ & Complicating factors ${ }^{\mathrm{C}}$ \\
\hline $\begin{array}{l}\text { Sillanpää ef al., } \\
1999 \text { [37] }\end{array}$ & $\begin{array}{l}\text { Otherwise normal } \\
\text { individuals with no clear } \\
\text { etiology }\end{array}$ & $\begin{array}{l}\text { Unclear, reclassification } \\
\text { was based on imaging }\end{array}$ & $\begin{array}{l}\text { Remote symp- } \\
\text { tomatic }\end{array}$ & Prospective & $\begin{array}{l}\text { sympiomatic epilepsy } \\
\text { diagnosed on basis of } \\
\text { localization }\end{array}$ \\
\hline Verrotti, $2000[14$ & $\begin{array}{l}\text { To be concluded from } \\
\text { exclusion criteria }\end{array}$ & $\begin{array}{l}\text { Cerebral CT and MRI } \\
\text { findings normal in all } \\
\text { children }\end{array}$ & Not considered & Prospective & $\begin{array}{l}\text { Seizure-free patients with } \\
\text { normal EEG }\end{array}$ \\
\hline Verrotti, $2000[20$ & $\begin{array}{l}\text { To be concluded from } \\
\text { exclusion criteria }\end{array}$ & $\begin{array}{l}\text { CT scan and MRI were } \\
\text { normal in all children }\end{array}$ & $\begin{array}{l}\text { Not included in } \\
\text { this study }\end{array}$ & Prospective & $\begin{array}{l}\text { Seizure-free patients with } \\
\text { normal EEG }\end{array}$ \\
\hline
\end{tabular}

${ }^{a}$ Definition of CLRE as applied by these authors; ${ }^{b}$ How authors dealt with an $10<70 ;{ }^{\circ}$ Other factors complicating the assessment of an article.

Therefore, studies in which developmental problems (i.e., clinically diagnosed mental retardation or $I Q<70$ ) were described within the cohort designated as having CLRE were excluded. However, studies in which such problems were not mentioned, and in which there was no reason to suspect mental delay of large impact in the described cohort, were not excluded.

In our opinion, CLRE can be diagnosed only after neuroimaging. Indeed, in nine studies normal neuroimaging was confirmed. ${ }^{14,17,18,20,22-24,32,34}$ One study did perform neuroimaging in the majority of the patients with $\mathrm{CLRE}^{15}$, but another did so in less than half of the patients. ${ }^{33}$ In 10 of the studies included, it was not clear whether all patients diagnosed as having CLRE had undergone neuroimaging (Table 2). ${ }^{4,5,7,19,25,26,28,29,31,35}$ Four studies did not mention neuroimaging at all. ${ }^{16,21,27,30}$ All but three studies ${ }^{27,30,33}$ were carried out in a prospective design. There are also methodological and general remarks to be considered regarding the included studies (Table 2). These issues are commented on under Results.

\section{Results}

\section{Diagnosis of CLRE}

The diagnosis epilepsy is by definition a clinical diagnosis and, thus, is subject to interrater (dis)agreement. Berg et al. ${ }^{4}$ studied this phenomenon in a large cohort of newly diagnosed children. Three child neurologists compared their diagnoses of 613 children with epilepsy. In the 103 cases of CLRE, there was full interrater agreement in 83 cases. The agreement parameter $\kappa$ was in the very good to excellent range for all types of epilepsy, ranging from 0.82 to 0.89 . The authors explained this excessively high score as the result of the large amount of information that can be used to diagnose a syndrome. CLRE was part of two of the three most commonly occurring disagreements: between CLRE and undetermined whether focal or generalized and without unequivocal focal or generalized features, classification depended on the 
interpretation of the seizures where EEG was not helpful; between CLRE and symptomatic localization related epilepsy, the disagreement involved the degree of localization on the EEG.

According to these and other authors, detecting an epileptic focus on $E E G^{4,5,29,31,35}$ would lead to the diagnosis SLRE (with the etiology marked as cryptogenic). In a later study, these authors departed from this method of classification ${ }^{7}$, and the shift between the CLRE and SLRE groups that can be seen comparing these studies is dramatic. ${ }^{7}$ The same cohort of patients with epilepsy then contained more than twice as many patients with CLRE. It is not possible to estimate the impact this finding has had on the outcomes for the CLRE group in the previous studies ${ }^{4,5,31}$, which are therefore less reliable sources for the concept of CLRE.

The group of patients with CLRE, by definition, will constantly be reassessed. With improvement in technology and diagnostic clinical insights, etiology is clarified and patients from this group are reclassified. ${ }^{5,25,35}$ Within a 2-year period, 14 of 103 patients with CLRE were rediagnosed as having SLRE. This was done on the basis of localization through EEG or etiologic clues. ${ }^{5}$ As mentioned earlier, this artificial method of classification, and hence of reclassification, decreases the reliability of this study for our review.

\section{Prognosis of seizure control}

The ILAE guidelines for epidemiologic studies propose 5 years of seizure freedom as a definition of remission. ${ }^{36}$ Such a long follow-up is not often feasible, so most studies apply their own definition of remission. Yet a lack of consensus makes it difficult to compare studies discussing remission.

Berg et al. defined remission as 2 years of seizure freedom. ${ }^{31}$ Among 99 patients with CLRE with a median follow-up of 5.3 years, $83 \%$ achieved remission at some time. Relapse occurred in $24 \%$. Many children regained remission. For ILRE, these figures were 93 and 7\% respectively, and for SLRE, 72\% (achieving 2-year remission) and $30 \%$ (relapse).

Shinnar et al. ${ }^{35}$ followed 182 children with all kinds of epilepsies for at least 2 years after diagnosis. Their definition of (terminal) remission was also 2 years of seizure freedom; they did not allow for relapse. Thirty-four children were classified as having CLRE. After a mean follow-up of 8.3 years, $82 \%$ were found to be in remission.

Camfield and Camfield studied a cohort of childhood epilepsies prospectively for more than 7 years. ${ }^{12,32}$ For the 132 children with CLRE, follow-up lasted $88 \pm 31$ months. Two-thirds of these children entered remission without medication. In $45 \%$ of the CLRE group, the epilepsy was considered to be truly benign, with instant seizure remission on initial treatment. However, in the other half of the cohort, the epilepsy was rather persistent.

Reporting on a 30-year prospective follow-up of childhood epilepsy, Sillanpää et al. initially included 40 CLRE patients, 8 of whom were lost to follow up ( 3 of these 8 died). ${ }^{37}$ Of the other 32 patients with CLRE, 20 were in remission. The classification of these patients dates back before the ILAE classification of $1989^{2}$, and before the 
widespread use of neuroimaging. Together with the aforementioned classification issues, this indicates the decreased reliability of this article for our review. Twenty of one hundred twenty patients with SLRE died. Forty-seven patients with SLRE were seizure-free. For the ILRE cohort, these figures describe a more benign course, with 18 of 23 patients being seizure-free. Still, 2 died during follow-up.

Hauser et al..$^{34}$ used 1 year of remission as an outcome variable. Within their CLRE group of 19 patients, $17(89 \%)$ reached 1 year of remission at some time. Some patients who had a 1-year remission relapsed, and some of them regained remission, but no specific figures are given. For comparison, all 26 patients with benign idiopathic focal epilepsy reached 1 year of remission, and 36 of 43 patients $(83.7 \%$ ) with SLRE did so.

Genton et al. ${ }^{33}$ regarded low seizure frequency as a "good outcome." Only $63 \%$ of their patients met this criterion. However, in 8 of their 38 patients with CLRE, onset of epilepsy occurred in the first year of life, and therefore, they had a worse prognosis. Also, only 15 underwent brain imaging, which made the cryptogenic etiology less certain, and a symptomatic etiology possible, with worse prognosis. Therefore, this cohort and the results do not seem very reliable for the purpose of this review.

Arts et al. ${ }^{25}$ investigated the short-term outcome of childhood epilepsy. They defined as poor outcome less than 6 months of terminal remission at an evaluation point 2 years after initial diagnosis. Of their children with CLRE, 37\%; of their children with SLRE, $46 \%$; and of their children with ILRE, $21 \%$ had a poor short-term outcome.

In a later study, the authors compared outcome and predicting variables at 2 and 5 years after diagnosis. ${ }^{19}$ For children with CLRE, $34 \%$ had a terminal remission of less than 1 year at 5 years after diagnosis compared with $48 \%$ at 2 years. The odds ratio (OR) of not having reached a longer than 1-year terminal remission at 5 years after diagnosis for the CLRE type of epilepsy ( 6 months after first diagnosis) is 2.76 ( $P<$ $0.001)$. For SLRE, the $O R$ is $3.45(P<0.001)$. By 5 years after diagnosis, all patients diagnosed with ILRE at 6 months had been seizure-free for at least 1 year.

Arts et al. analyzed the determinants of CLRE and SLRE predicting >1-year terminal remission 5 years after diagnosis, as they argue these children cannot depend on a defined syndrome to predict their prognosis. The occurrence of postictal signs is the only significant determinant, still amounting to $33 \%$ of mispredictions. As for specific variables within the CLRE cohort, age at onset between 3 and 9 is noted to predict a worse prognosis; this finding is significant.

Collaborating with Camfield and colleagues, these authors tried to build a prediction model based on models developed by both research groups. ${ }^{30}$ The outcome measure was "off medication at the end of follow-up." For CLRE, percentages did not differ among the two cohorts (Camfield et al., Nova Scotia cohort: 62\%; Geelhoed et al., Dutch cohort: $56 \%$ ). In contrast to the Dutch model, the Nova Scotia model as well as the combined model attributed a good outcome to CLRE.

In a clinical trial, 72 previously untreated children with CLRE were treated with zonisamide monotherapy. ${ }^{16}$ When zonisamide did not suffice, carbamazepine was added. Seizure control was attained by 57 patients $(79.2 \%)$. Five patients experienced cognitive side effects (short attention span and drowsiness). 
In a topiramate trial, 5 of 7 children with CLRE who were treated with topiramate addon therapy were regarded as responders. ${ }^{17}$ For SLRE, 7 of 12 responded, and for ILRE, 1 of 2 children responded.

In the case of persisting seizure freedom, drug withdrawal is considered. Within a CLRE cohort of seizure-free children with a normal EEG, Verrotti et al. determined the rate of relapse to be $27 \% .{ }^{14}$ There was no difference with respect to the outcome of withdrawal between 1 and 2 years of seizure freedom. It is generally believed that a normal EEG decreases the risk for relapse, so a more benign part of the CLRE population may be reflected in this study.

Ohta et al. retrospectively diagnosed children with CLRE to study their long-term outcome. ${ }^{28}$ They found two independent risk factors for relapse after withdrawal of antiepileptic drugs (AEDs): first, 5 years or more from start of AED therapy until seizure remission, and second, age at onset of epilepsy of 6 or older. The low relapse rate $(9.8 \%$ ) reflects their criteria before withdrawal $(3$ or more years of seizure freedom and no abnormalities on EEG tracings).

According to Murakami et al., remaining EEG abnormalities despite drug therapy and seizure freedom did not predict the occurrence of a relapse after AED withdrawal. ${ }^{27}$ Moreover, the relapse rate of the CLRE group was significantly lower $(8.6 \%)$ than the relapse rate of the total cohort consisting of childhood epilepsy patients (13.5\%) with 3 years of seizure freedom. Also, the comparison with the SLRE cohort, which has a relapse rate of $20.0 \%$, is striking; however the ILRE cohort had a relapse rate similar to that of the CLRE cohort ( $8.3 \%)$.

Verrotti et al. evaluated the predictive value of interictal EEG findings during drug withdrawal..$^{20}$ Their patients did not exhibit any EEG abnormalities on three different occasions before drug withdrawal. Relapse occurred in $24 \%$. EEG abnormalities were exhibited by $67 \%$ of children who relapsed versus $10 \%$ of children who did not relapse. They concluded that reappearance of EEG abnormalities after drug withdrawal is a risk factor for relapse.

Recently, Berg et al. applied a Markov process to model the course of several epilepsy groups. ${ }^{7}$ This method characterizes remissions and relapses in a more quantitative way. It examines the probability of being in a given state, can follow the individual as he or she changes state, and allows for calculation of the net effects. First, they defined three possible states of epilepsy: not yet being in remission, being in a remission of 1 year, and having relapsed after at least 1 year of remission. Their results for CLRE were similar to the results for IGE: neither a very benign nor a very malignant course. Throughout the whole study CLRE could be found right between ILRE, with the more benign course, and SLRE, with the markedly worse outcome. In a second phase, they analyzed the course of the epilepsy in more detail, implementing a second and third state of remission and accompanying relapses. Now the difference between IGE and CLRE became clear: Patients with IGE almost never relapsed; however, patients with CLRE exhibited a pattern of remission and relapse. This wavelike pattern could have an important effect on the personal development of patients. However, this pattern could also be merely a consequence of the method 
applied. This will have to be confirmed in further studies on the course of seizure control.

\section{Cognitive and psychosocial prognosis}

A precondition for attention is a normal state of responsiveness. Attention plays a key role in learning processes. Oostrom et al. stated that attention seemed to be the outstanding function reflecting the behavioral or cognitive effects of epilepsy. They did not find any significant difference in attention and reaction time between the cryptogenic group and the idiopathic group or the controls. ${ }^{23}$

Parkinson studied the relationship between presence of language disorders and type of epileptic seizures in children. Within the subgroup of children with language disorders, significantly more children had partial than generalized seizure types. A larger percentage of these children had SLRE than CLRE. Because these patients belong to a group noted for the refractory nature of their epilepsy, and more than two-thirds of these children attend special education classes ${ }^{26}$, these results are not applicable for generating a prognosis for patients with CLRE.

In a population-based study, Hoie et al. studied the prevalence of severe nonverbal problems (SNVPs) with the Raven Matrices in children with epilepsy and in healthy controls. The Raven Matrices is a robust nonverbal reasoning ability test based on figural test stimuli in the visual modality. SNVPs were considered to exist if the Raven score was at or below the 10th percentile. ${ }^{15}$ Children with epilepsy were highly overrepresented in the lowest Raven percentile group, whereas controls were highly overrepresented in the higher percentile groups. Five of the twenty-five children with CLRE (20\%) had SNVPs; for ILRE this was $7 \%$, and for SLRE $62 \%$. Only $3 \%$ of the healthy controls scored below the 10th percentile.

Oostrom et al. found that groups of children with idiopathic or cryptogenic epilepsy and controls could not be distinguished by their IQs or attitudes toward school. ${ }^{23}$ Not significantly more children with epilepsy than controls repeated a year at school. However, significantly more children with epilepsy, including the subgroup of children with CLRE, required special education assistance at school. ${ }^{23}$

Oostrom et al. stated that at 3 to 4 years of follow-up ${ }^{18}$, both parents and teachers reported more behavioral problems for the group of children with epilepsy only than for healthy controls. Also, the epilepsy-only group was reported as performing worse on measures of learning, memory span for words, and attention. After they controlled for school delay, only proactive interference remained a significant finding. None of these findings distinguishes the children with CLRE from the children with ILRE. ${ }^{18}$

Aldenkamp and Arends studied two scholastic variables, reading and arithmetic, in a cohort of children with nonconvulsive seizures and learning problems. ${ }^{21}$ The control group in this study consisted of 31 children in whom the diagnosis epilepsy was rejected. All of these children had a normal $I Q$ and no other neurological disorders. The results indicated no delay in reading for the control group, whereas the children with CLRE had a delay of 19.2 months. The idiopathic and symptomatic groups had delays of respectively 2.3 and 12.2 months. For arithmetic, the same pattern was ob- 
served, although the difference was somewhat smalier. The control group had a delay of 3.9 months, the CLRE group had a delay of 17.0 months, and the idiopathic and symptomatic groups had delays of respectively 4.5 and 13.2 months. Because in these tests, a 10-month delay equals a full school year, the delay in both reading and arithmetic was almost 2 school years for the children with CLRE. ${ }^{21}$

In general, schoolchildren with epilepsy have more behavioral problems than their healthy classmates. Oostrom et al. ${ }^{22}$ studied the occurrence of behavioral problems in children with cryptogenic and idiopathic epilepsy. The only specific result was that children with cryptogenic epilepsy were rated as having significantly more behavioral problems than children with idiopathic epilepsy and children from the control group on the Child Behavior Checklist (CBCL). Oostrom et al. gave two possible explanations. First, cerebral dysfunction may contribute to the behavioral problems. ${ }^{22}$ Second, because many parents of children with cryptogenic epilepsy perceived themselves as having been thrown off balance at the onset of the epilepsy, this stress in the parent(s) could be related to behavioral problems in children with epilepsy. ${ }^{24}$

Genton et al. studied the psychosocial outcome of nonidiopathic focal childhood epilepsies. ${ }^{33}$ Outcome was categorized as either "normal" or "abnormal." A normal outcome was defined as "lack of evident neuropsychological deficit and normal schooling and/or unrestricted choice of profession and lifestyle, as well as absence of any behavioral problems." The psychosocial outcome in this study was poor, because at the end of the follow-up period, only $50 \%$ of the cryptogenic patients and only $13 \%$ of the symptomatic cases were reported as "normal." It must be taken into account that $55 \%$ of the total cohort was already categorized as "abnormal" at the start of the study. Even though the patients with cryptogenic epilepsy seemed to have a somewhat better evolution than the patients with symptomatic epilepsy ${ }^{33}$, a score of only $50 \%$ with "normal outcome" can hardly be regarded "better."

\section{Discussion}

On review of the literature on CLRE with childhood onset, six articles provide information that is considered of value in describing prognosis. The short-term prognosis is generally good ${ }^{25}$ ( 2 years after diagnosis, almost two-thirds of patients have been seizure-free for 6 months), and in the long term, the chance of achieving seizure freedom also is good ${ }^{34}$ ( $89 \%$ of patients reach a 1 -year remission). However, relapse occurs frequently. ${ }^{7}$ Also, children with CLRE experience academic and behavioral difficulties. ${ }^{22,23}$ The prognosis seems to be unpredictable, as both benign and malignant courses are described. ${ }^{12}$

\section{Diagnosis of CLRE}

In the 2001 proposal for a diagnostic scheme as an expansion of the classification, cryptogenic is replaced by probably symptomatic. ${ }^{38}$ This scheme is divided into axes; 
on the third axis a syndromic diagnosis is given, whenever possible. On this axis, the former category CLRE is incorporated into "symptomatic (or probably symptomatic) focal epilepsies," more specifically "Other Types Defined by Location and Etiology." The nonspecificity remains.

Even before this proposal, CLRE was often assigned to the same research cohort as SLRE. This explains the limited amount of information we were able to retrieve from the literature. Even though many of these patients with CLRE will eventually be recognized as having SLRE, this requires focused research on a clearly defined cohort.

\section{Prognosis for seizure control}

Unfortunately, impressive studies ${ }^{4,5,29,31,35}$ were substantially flawed with respect to the CLRE cohort. Camfield and Camfield ${ }^{32}$ report widely differing seizure outcomes: up to half of their cohort had a truly benign course, whereas in the other half, prognosis was uncertain.

In an innovative approach, Berg et al. applied a Markov process to describe the course of epilepsy. They suggest that there may exist a wavelike pattern of relapse and remission ${ }^{7}$, which might be distinct for CLRE. This finding has not yet been reproduced. The overall question is whether there is a relationship between the clinical appearance of CLRE with respect to seizure control and the worrisome neuropsychological outcome.

\section{Cognitive and psychosocial prognosis}

Even though it is known that children with epilepsy are at risk for cognitive delay ${ }^{10,21,39}$, little can be confirmed concerning CLRE specifically. For some children with CLRE, the consequences have proven to be serious. Delays up to two school years in reading and arithmetic have been reported. ${ }^{21}$ Even though the children in this study were included because of fluctuations in cognitive performance, it is noteworthy that the children with CLRE had dramatically worse delays than the children with symptomatic or idiopathic epilepsy. Also, according to another study, patients with CLRE had more behavioral problems in comparison with their healthy peers, but also in comparison with children with idiopathic epilepsy. ${ }^{22}$

\section{Heterogeneity within CLRE}

It seems reasonable to assume that the CLRE group, like the SLRE group, comprises several subgroups. Major risk factors such as etiology and syndrome diagnosis are irrelevant in predicting the prognosis of CLRE. Therefore, other, apparently superficial factors may be more important when studying CLRE subgroups. Of course, these are the factors that define epilepsy syndromes in general.

For CLRE as an undefined group, these factors take on a wide variety of values, and the challenge is to recognize combinations of these to predict prognosis. 
From this review, several factors can be suggested as important in prognosis. First, age at onset between 5 and 9 was found to predict attainment of remission, regardless of syndrome. ${ }^{31}$ On the other hand, age at onset after 6 was found to be an independent risk factor for seizure relapse after AED withdrawal in children with CLRE. ${ }^{28}$ Ohta et al. partly explain their outcomes as the result of the diversity of their population. ${ }^{28} \mathrm{~A}$ portion of the children in their cohort may turn out to have benign partial epilepsy, which seems idiopathic because of the high rate of family history, age at onset below 6 , and benign course.

Second, a direct way to break down the large and cluttered CLRE-population is by semiology of the seizures. With a highly developed classification such as Luders ${ }^{40}$, semiology can be correlated with other outcome measures. It has previously been described how seizure semiology can predict clinical outcome. It is also known that for epilepsy in general, patients with more than one seizure type are at greater risk with respect to both seizure outcome and cognitive outcome, especially if the epilepsy is associated with neurological deficit or psychiatric or behavioral disturbances. ${ }^{11}$ In particular, a possible correlation between a pattern of recurrent remission and relapse and the disruption of cognitive development in children with CLRE should be explored.

Third, seizure frequency may be a factor. Children with low seizure frequency can fit into the so-called benign subgroups of CLRE, whereas patients with frequent seizures may constitute more malignant subgroups. Those children with CLRE who experience subtle seizures may pose a dilemma with respect to prognosis. ${ }^{41}$ The failure to notice the many seizures they experience may explain the malignant outcome in the presence of an apparently low seizure frequency. ${ }^{21}$

Fourth, (in)tractability of the epilepsy seems to be a very important factor. The number of seizures experienced before medication is also described as a risk factor. ${ }^{32}$ Ohta et al. reported that the time between the start of an AED and seizure control is a prognostic factor in the patient's chance of relapse [28]. The current number of AEDs, the number of AEDs tried in the past, and also the kinds of AEDs are essential. Together, these factors can also distinguish benign from malignant subgroups. Arts et al. $^{25}$ wonder: Does the refractory epilepsy make the patient insensitive to treatment, or are the ongoing seizures worsening the course of the epilepsy and determining the prognosis of their cohort, consisting predominantly of CLRE and SLRE patients? Regardless of diagnosis, one-third of epilepsy patients appear to be resistant to drug therapy. Bearing in mind the hypothesis of "seizures beget seizures," research on patient drug matches is very important. Pharmacogenetic research has led to the assumption of subgroups within diseases, which, although indistinguishable on clinical grounds, are different on a molecular level. These would lead to specific approaches regarding treatment.

Fifth, a high percentage of epileptiform activity on EEGs can be a risk factor for cognitive skills. ${ }^{21}$ Two possible explanatory EEG features are nocturnal epileptiform activity and interictal epileptiform activity irrespective of time of day. It is known that nocturnal epileptiform activity strongly affects cognitive skills. ${ }^{42}$ Landau-Kleffner and ESES can be considered extreme syndromes in such a spectrum. A less often de- 
scribed but powerful relationship exists between daytime interictal epileptiform activity and cognitive impairment. Even a little daytime interictal epileptiform activity, only $1 \%$ of the time, has an important noticeable effect on cognition, compared with the high percentages of interictal epileptiform activity in children with ESES, in whom discharges are generally observed more than $85 \%$ of the time..$^{21}$ Further quantification of these EEG features may contribute to the identification of different subgroups within CLRE.

Lastly, according to Camfield and Camfield ${ }^{32}, I Q$ predicts long-term outcome better than neurological deficit does. Epilepsy patients were divided into those with normal $I Q$ and those with abnormal IQ. Some clinicians diagnose localization related epilepsy in the presence of mental retardation as symptomatic, and others do not, or do so on the matter of diagnosis, but not when discussing etiology. Thus, it seems a matter of opinion whether this could be a prognostic factor in CLRE. When the diagnostic scheme proposed by Engel ${ }^{38}$ is used, etiology (axis 4) is in fact appointed independent of impairment (axis 5). We suggest that differences within the normal range of $I Q$ could also have meaning for subgroups. Therefore, premorbid $I Q$ could be a distinguishing characteristic within the CLRE cohort.

These subgroups may explain the wide variety of outcomes of previous studies and the unpredictable outcome of CLRE in individual cases. In every study published so far, one subgroup might have unintentionally been overrepresented, which strongly influenced the outcome for the entire CLRE cohort.

In conclusion, CLRE remains a diagnosis that is difficult to grasp. In clinical research it has had a subordinate position, which is not in proportion either to the prevalence of CLRE in the pediatric epilepsy population or to the not so benign prognosis that can be expected for at least part of this group. Prospective studies on well-defined CLRE cohorts are needed to identify factors that distinguish various prognostic subgroups. Specific attention should be focused on course of the epilepsy, scholastic achievement, and psychosocial outcome. 


\section{References}

1. Duncan J, Shorvon S, Fish D. Clinical epilepsy. New York: Churchill Livingstone; 1995.

2. Commission on Classification and Terminology of the International League Against Epilepsy Proposal for revised classification ofepilepsies and epileptic syndromes. Epilepsia 1989;30:389-399.

3. Dunn DW, Buelow JM, Austin JK, et al. Development of syndrome severity scores for pediatric epilepsy. Epilepsia 2004;45:661-6.

4. Berg AT, Levy SR, Testa FM, et al. Classification of childhood epilepsy syndromes in newly diagnosed epilepsy: interrater agreement and reasons for disagreement. Epilepsia 1999;40:439-44.

5. Berg AT, Shinnar S, Levy SR, et al. How well can epilepsy syndromes be identified at diagnosis? A reassessment 2 years after initial diagnosis. Epilepsia 2000;41:1269-75.

6. Kellinghaus $\mathrm{C}$, Loddenkemper $\mathrm{T}$, Najm $\mathbf{I M}$, et al. Specific epileptic syndromes are rare even in tertiary epilepsy centers: a patient-oriented approach to epilepsy classification. Epilepsia 2004;45:268-75.

7. Berg AT, Lin J, Ebrahimi N, et al. Modeling remission and relapse in pediatric epilepsy: application of a Markov process. Epilepsy Res 2004;60:31-40.

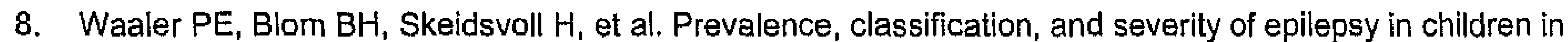
western Norway. Epilepsia 2000;41:802-10.

9. Eriksson KJ, Koivikko MJ. Prevalence, classification, and severity of epilepsy and epileptic syndromes in children. Epilepsia 1997;38:1275-82.

10. Cascino G, Hopkins A, Shorvon SD, editors. Epilepsy. 2nd ed. London/New York: Chapman \& Hall; 1995. p. 503. [chapter xvii].

11. Sander JW. Some aspects of prognosis in the epilepsies; a review. Epilepsia 1993;34:1007-16.

12. Camfield $P$, Camfield $C$. Epileptic syndromes in childhood: clinical features, outcomes, and treatment. Epilepsia 2002;43(Suppl. 3):27-32.

13. Camfield $P$, Camfield $C$. Childhood epilepsy: what is the evidence for what we think and what we do? $\mathrm{J}$ Child Neurol 2003;18:272-87.

14. Verrotti A, Morresi $S$, Basciani $F$, et al. Discontinuation of anticonvulsant therapy in children with partial epilepsy. Neurology 2000;55:1393-5.

15. Hoie $B$, Mykletun $A$, Sommerfelt $K$, et al. Seizure-related factors and non-verbal intelligence in children with epilepsy: a populationbased study from western Norway. Seizure $2005 ; 14: 223-31$.

16. Miura $\mathrm{H}$. Zonisamide monotherapy with once-daily dosing in children with cryptogenic localization-related epilepsies: clinical effects and pharmacokinetic studies. Seizure 2004;13 (Suppl. 1):S17-23. discussion \$24-5.

17. Grosso S, Galimberti D, Farnetani $M A_{1}$ et al. Efficacy and safety of topiramate in infants according to epilepsy syndromes. Seizure 2005;14:183-9.

18. Oostrom KJ, van Teeseling $H$, Smeets-Schouten $A$, et al. Three to four years after diagnosis: cognition and behaviour in children with 'epilepsy only'. A prospective, controlled study. Brain 2005;128 (Pt. 7):1546-55.

19. Arts WF, Brouwer OF, Peters AC, et al. Course and prognosis of childhood epilepsy: 5-year follow-up of the Dutch study of epilepsy in childhood. Brain 2004;127(Pt. 8):1774-84.

20. Verrotti $A$, Morresi $S$, Cutarella $R$, et al. Predictive value of EEG monitoring during drug withdrawal in children with cryptogenic partial epilepsy. Neurophysiol Clin 2000;30:240-5.

21. Aldenkamp A, Arends J. The relative influence of epileptic EEG discharges, short nonconvulsive seizures, and type of epilepsy on cognitive function. Epilepsia 2004:45:54-63. 
22. Oostrom $\mathrm{KJ}$, Schouten $\mathrm{A}, \mathrm{Kruitwagen} \mathrm{CL}$, et al. Behavioral problems in children with newly diagnosed idiopathic or cryptogenic epilepsy attending normal schools are in majority not persistent. Epilepsia 2003:44:97-106.

23. Oostrom $\mathrm{KJ}$, Schouten $\mathrm{A}$, Kruitwagen $\mathrm{CL}$, et al. Attention deficits are not characteristic of schoolchildren with newly diagnosed idiopathic or cryptogenic epilepsy. Epilepsia 2002;43:301-10.

24. Oostrom KJ, Schouten A, Kruitwagen CL, et al. Parents' perceptions of adversity introduced by upheaval and uncertainty at the onset of childhood epilepsy. Epilepsia 2001;42:1452-60.

25. Arts WF, Geerts AT, Brouwer OF, et al. The early prognosis of epilepsy in childhood: the prediction of a poor outcome. The Dutch study of epilepsy in childhood. Epilepsia 1999;40:726-34.

26. Parkinson GM. High incidence of language disorder in children with focal epilepsies. Dev Med Child Neurol 2002;44:533-7.

27. Murakami $M$, Konishi T, Naganuma $Y$, et al. Withdrawal of antiepileptic drug treatment in childhood epilepsy: factors related to age. J Neurol Neurosurg Psychiatry 1995:59:477-81.

28. Ohta $\mathrm{H}$, Ohtsuka $\mathrm{Y}, \mathrm{T}$ suda $\mathrm{T}$, et al. Prognosis after withdrawal of antiepileptic drugs in childhood-onset cryptogenic localization-related epilepsies. Brain Dev 2004;26:19-25.

29. Sillanpää $M$, Jalava $M$, Kaleva $O$, et al, Long-term prognosis of seizures with onset in childhood. $N$ Engl $J$ Med 1998;338:1715-22.

30. Geeihoed $M$, Boerrigter $A O$, Camfield $P$, et al. The accuracy of outcome prediction models for childhoodonset epilepsy. Epilepsia 2005;46:1526-32.

31. Berg AT, Shinnar S, Levy SR, et al. Two-year remission and subsequent relapse in children with newly diagnosed epilepsy. Epilepsia 2001:42:1553-62.

32. Camfield $\mathrm{C}$, Camfield $\mathrm{P}$. Predicting the outcome of childhood epilepsy: a population-based study yielding a simple scoring system. J Pediatr 1993;122:861-8.

33. Genton $P$, Battaglia D, Pinto $P$, et al. Long-term outcome of nonidiopathic focal childhood epilepsies: a retrospective study of 106 cases including 33 cases with extensive evaluation and follow-up. In: Tuxhorn $J$, Holthausen $H$, Boenigk $H$, editors. Paediatric epilepsy syndromes and their surgical treatment. London: John Libbey; 1997. p. 47-54.

34. Hauser E, Freilinger $M$, Seidl $R$, et al. Prognosis of childhood epilepsy in newly referred patients. J Child Neurol 1996;11:201-4

35. Shinnar S, O'Dell C, Berg AT. Distribution of epilepsy syndromes in a cohort of children prospectively monitored from the time of their first unprovoked seizure. Epilepsia 1999;40:1378-83.

36. Commission on Epidemiology and Prognosis, International League Against Epilepsy. Guidelines for epidemiologic studies on epilepsy. Epilepsia 1993;34:592-6.

37. Sillanpäa $M$, Jalava $M$, Shinnar S. Epilepsy syndromes in patients with childhood-onset seizures in Finland. Pediatr Neurol 1999;21:533-7.

38. Engel Jr J. A proposed diagnostic scheme for people with epileptic seizures and with epilepsy; report of the ILAE Task Force on Classification and Terminology. Epilepsia 2001;42:796-803.

39. Seidenberg $M$, Beck N, Geisser $M$, et al. Academic achievement of children with epilepsy. Epilepsia $1986 ; 27: 753-9$.

40. Luders H, Acharya J, Baumgartner $C$, et al. Semiological seizure classification. Epilepsia 1998;39:1006-13.

41. Aldenkamp AP, Overweg-Plandsoen WC, Arends J. An open, nonrandomized clinical comparative study evaluating the effect of epilepsy on learning. J Child Neurol 1999;14:795-800.

42. Baglietto MG, Battaglia FM, Nobili $L$, et al. Neuropsychological disorders related to interictal epileptic discharges during sleep in benign epilepsy of childhood with centrotemporal or Rolandic spikes. Dev Med Child Neurol 2001;43:407-12. 


\section{Chapter Two}

The validity of a separate classification of cryptogenic localization related epilepsy amongst childhood epilepsies 


\begin{abstract}
Introduction One third of children with epilepsy are classified as having a cryptogenic localization related epilepsy (CLRE). In cohort studies CLRE is often grouped together with either symptomatic localization related epilepsy (SLRE) or idiopathic generalized epilepsy (IGE). Therefore, this categorization is not specific enough and will not lead to prognostic or treatment information. We objectified the classification differences between these categories.
\end{abstract}

Methods A total of 114 children admitted to our epilepsy centre underwent a standardized clinical analysis, which yielded age at onset, duration of the epilepsy, seizure frequency, seizure type, percentage of interictal epileptiform activity on EEG (IEA), type of treatment, and full scale IQ. These variables are regarded the characteristics of the epilepsy, and used in a discriminant function analysis.

Results IEA was found to be the only variable to distinguish between groups of epilepsy. SLRE could easily be distinguished significantly from IGE and CLRE, while the latter two did not differ significantly. Discriminant function analysis combined the variables into two functions, applicable to classify the children. By applying this statistical analysis method, the groups clinically classified as SLRE and IGE were mostly classified as SLRE $(81 \%)$ and IGE $(63.2 \%)$. However, CLRE appeared difficult to classify $(46 \%)$, and most children were classified as either SLRE (19\%) or IGE $(34.9 \%)$.

Conclusion The current opinion that CLRE is 'probably symptomatic' cannot be confirmed in all cases in this study. Neither can all children with CLRE be grouped with IGE. Therefore, we emphasize the need for seperate studies regarding children with 'probably symptomatic' (cryptogenic) localization related epilepsy.

Published as:

Reijs RP, van Mil SG, van Hall MH, Arends JB, Weber JW, Renier WO, Aldenkamp AP. The validity of a separate classification of cryptogenic localization related epilepsy amongst childhood epilepsies.

Seizure. 2007 Jul;16(5):438-44. 


\section{Introduction}

One-third of children with epilepsy are classified as having cryptogenic localization related epilepsy (CLRE) according to the ILAE Classification of Epilepsies and Epileptic Syndromes, the most widely used classification in clinical epilepsy practice. ${ }^{1-4}$ The main advantage of using a well-defined classification is clear communication amongst clinicians and researchers. However, the ILAE classification has been criticised because of several unspecific categories. ${ }^{5-7}$ One of these is CLRE. As yet it is unclear whether this classification will help us determine prognosis or preferred care. Without a known aetiology (such as stroke or a tumour) or a syndromatic diagnosis (such as Lennox Gastaut), the main characteristics of an epilepsy must be used to interpret its severity and try to predict its course. For CLRE a variety of epilepsyrelated factors have been identified in previous research. Seizure frequency is an important factor and often used as an outcome measure. Age at onset is associated with the rate of remission and relapse after withdrawal of anti-epileptic drug treatment $(A E D)^{8,9}$ Seizure type, and more specifically the occurrence of more than one seizure type is associated with an increased risk for poor outcome. ${ }^{10}$ As for other types of epilepsy, an epilepsy that does not or not easily respond to AED has a worse outcome. ${ }^{9}$ Interictal epileptiform activity on EEG (IEA), even as little as $1 \%$ of the time, was correlated with worse cognitive outcome. ${ }^{11,12}$ Also, an abnormal IQ-score was found to be a predictor of worse long term outcome of epilepsy. ${ }^{13}$ Therefore, age at onset, seizure type, seizure frequency, EEG-characteristics, response to treatment and IQ have been identified the main parameters defining the epilepsy.

A few studies are available that describe cohorts of children with CLRE. ${ }^{14}$ All too often, children with CLRE are put together with symptomatic localization related epilepsy (SLRE) when prognosis or treatment effects are studied. ${ }^{15,16}$ Remarkably, sometimes CLRE is grouped together with idiopathic generalized epilepsy (IGE). ${ }^{17}$ In this study, we tried to objectify the position of CLRE amongst these types of epilepsy, by using the aforementioned characteristics as underlying classification variables. The validity of a separate category for CLRE based on the most important clinical variables was evaluated. We used a statistical technique, specifically designed to test classifications: discriminant function analysis.

\section{Methods}

Patients

Data were obtained from 114 children admitted to our epilepsy centre in a child neurological programme between January 1999 and December 2004. Children were referred because of questions regarding their epilepsy (i.e. diagnostic or treatment issues), or neuropsychological, educational or behavioural questions. 
Inclusion criteria for this study: Age at admission 6-16 years, diagnosis of CLRE, IGE or SLRE. The diagnoses were made or confirmed by (child) neurologists M.D., J.W. and L.N. at our epilepsy centre using the ILAE classification.'

- CLRE: Non-idiopathic localization related epilepsy without a known or suspected aetiology, neuroimaging without abnormality;

- IGE: Generalized epilepsy with no underlying cause other than a possible hereditary predisposition;

- SLRE: Localization related epilepsy considered the consequence of a known or suspected disorder of the central nervous system.

Exclusion criteria: $I Q<70$, or any known psychiatric disorder.

\section{Assessments}

A standardized protocol of assessments was used during a three-day admission at our epilepsy centre. Amongst others, this protocol included:

- Standardized extensive history taking of patients and their parents, yielding demographical information, as well as information on the epilepsy of the child.

- Wechsler Intelligence Scale for Children-Revised for The Netherlands (WISC-RN), yielding the full-scale $I Q$.

- 32 channel EEG recording for each child. The type of EEG (either routine $30 \mathrm{~min}$ or $24 \mathrm{~h}$ ambulatory recording) depended on the indication set by the treating neurologist. The percentage of time with epileptiform activity on the interictal EEG (interictal epileptiform activity, IEA) was measured.

\section{Design}

To study whether SLRE, IGE and CLRE are objectively distinguishable, a statistical method was used to classify the children using the following epilepsy-related variables:

- Age at onset.

- Duration of the epilepsy

- Seizure type

- Seizure frequency

- AED treatment (no therapy, monotherapy, and polytherapy)

- Presence of epileptiform activity in the interictal EEG (no IEA, IEA > 1\% of recording time)

- Full-scale IQ

Before analysis, seizure frequency and seizure type were categorized.

Seizure type was classified using the ILAE classification ${ }^{19}$ and subsequently categorized into four categories:

a. Partial seizures with a simple onset.

b. Partial seizures with a complex onset. 
c. Seizures with an immediate generalized semiology, whether primarily or secondarily generalized.

d. More than one seizure type.

Seizure frequency was categorized into three categories:

1. Seizure free for at least 1 year.

2. Low seizure frequency, ranging from one seizure in the previous year up to one seizure per month.

3. High seizure frequency, ranging from more than one seizure per month to daily seizures.

Whenever a child had more than one seizure type, the neurologists in the program stated which type was the primary seizure type. Usually this was the type with the highest frequency. This frequency was than used to score the variable 'seizure frequency'.

\section{Statistical analysis}

The data were collected on record forms, and entered into a database. The Statistical Package for Social Sciences (SPSS), Version 12.0.1 for Windows was used to process these data.

Discriminant function analysis was performed. This is a statistical technique that allows classification of a set of subjects. The goal of discriminant function analysis is to identify the factors, and the weight of these factors that discriminate between groups of subjects. The technique uses the previously described epilepsy-related variables and combines these into 'functions'. Such functions are constructed to maximize differences between groups for the individual patients, independent of the clinical classification into type of epilepsy. Subsequently, the constructed classification based on the epilepsy-related variables ('functions') and the clinical classification into CLRE, IGE and SLRE are compared.

The significance level (two-tailed testing) was set at $5 \%$.

The analysis was performed with equal prior probability for any given subject to be classified into each of the three constructed classifications. Only cases with complete records included in the analysis.

\section{Results}

The cohort consisted of 21 children with IGE, 25 children with SLRE and 68 children with CLRE. Of the original 114 cases, 11 were dropped from analysis because of missing data. The missing data were randomly scattered throughout the groups. In total, data coming from 103 children were used for discriminant function analysis (19 IGE, 21 SLRE, 63 CLRE).

Characteristics of the three groups are summarized in Table 1. 
Table 1. Characteristics of the three groups of types of epilepsy

\begin{tabular}{lccc}
\hline & IGE $(n=21)$ & SLRE $(n=25)$ & CLRE $(n=68)$ \\
\hline Age at assessment (months) & 117 & 129 & 123 \\
Age at onset (months) & 62 & 60 & 75 \\
Duration of epilepsy (months) & 54 & 75 & 48 \\
IQ & 87 & 83 & 88
\end{tabular}

Seizure type

Partial seizures

Complex partial seizures

Generalized seizures

More than one seizure type

Seizure frequency

\section{Seizure free}

Low seizure frequency

High seizure frequency

87

83

88

Epileptiform activity on interictal EEG (IEA)

No epileptiform activity

$>1 \%$ of the time

$\begin{array}{rrr}0 & 1 & 6 \\ 0 & 14 & 19 \\ 19 & 5 & 10 \\ 2 & 5 & 33\end{array}$

AED treatment

No therapy

Monotherapy

7

9

13

5

6

22

9

10

33

Polytherapy

18

IGE, idiopathic generalized epilepsy; SLRE, symptomatic localization related epilepsy; CLRE, cryptogenic localization related epilepsy

All but three of the children classified as IGE were diagnosed with Childhood Absence Epilepsy (CAE); three children were diagnosed as primary generalized epilepsy, not further defined. The underlying pathologies of the children with SLRE are summarized in Table 2.

Table 3 shows that IEA is the most important factor distinguishing the clinically classified three groups (IGE, SLRE, and CLRE) $(p=<.001)$. Children with SLRE show significantly more epileptiform activity on the EEG than children from the other two groups. Duration of epilepsy also distinguishes between the groups with statistical significance $(p=.021)$. The epilepsy of the children with SLRE had a longer duration, when compared to the children with IGE, who had a longer duration than children with CLRE. 
Table 2. Underlying pathologies of children with SLRE

\begin{tabular}{ll}
\hline & Frequency \\
\hline MTS & 2 \\
Corpus callosum agenesia & 1 \\
Cortical dysplasia & 1 \\
Migration disorder & 1 \\
Heterotopia & 1 \\
Tuberous sclerosis & 1 \\
Cysts and gliosis & 2 \\
Post-surgery & 3 \\
Post-infectious & 1 \\
Post-traumatic & 2 \\
Tumour & 1 \\
Intracerebral hematoma & 3 \\
Perinatal hypoxia & 5 \\
Pyramidal syndrome & 1 \\
\hline
\end{tabular}

Table 3. Comparison of the clinically classified groups with regards to the included variables

\begin{tabular}{lccccc}
\hline & Wilks' Lambda & F & d.f. 1 & & Sig. \\
\hline Age at onset & .976 & 1.227 & 2 & 100 & .297 \\
Duration of the epilepsy & .926 & 3.998 & 2 & 100 & $.021^{*}$ \\
AED & .984 & .828 & 2 & 100 & .440 \\
Seizure type & .963 & 1.919 & 2 & 100 & .152 \\
Seizure frequency & .968 & 1.654 & 2 & 100 & .196 \\
IEA & .843 & 9.331 & 2 & 100 & $<.001^{*}$ \\
IQ & .982 & .937 & 2 & 100 & .395 \\
\hline
\end{tabular}

$p$-Values $<.05$

Subsequently, the discriminant function analysis yields two functions, built on a combination of the epilepsy-related variables (so-called canonical discriminant functions). These functions are used to separate the cases and classify them into three groups. The structures of the functions and the correlation coefficients for each epilepsyrelated variable are shown in Table 4.

Table 4. Structure matrix of functions

\begin{tabular}{lll}
\hline & \multicolumn{2}{l}{ Function } \\
\hline IEA & \multicolumn{2}{l}{2} \\
Duration of the epilepsy & $.662^{*}$ & .368 \\
Seizure type & $.421^{*}$ & -.360 \\
IQ & $-.306^{*}$ & -.067 \\
Seizure frequency & $-.213^{*}$ & -.068 \\
AED & -.180 & $.585^{*}$ \\
Age at onset & -.033 & $.527^{*}$ \\
\hline
\end{tabular}

Largest absolute correlation between each variable and any discriminant function. 
Of the included variables, IEA contributes the most to the first function, which is to be expected from the previous comparisons of group means (correlation of 662). The presence of IEA leads to a higher correlation with function 1. A longer duration of the epilepsy has the same effect, but less strong. Seizure type is of more influence on the classification than is seizure frequency. Having a high seizure frequency has a stronger correlation with function 2, as does having polytherapy and an older age at onset. The other variables do not substantially contribute to the any of the functions (correlations <.30).

Table 5 shows that the first function will maximally separate the three groups. Thus, this function will classify most of the children in a constructed classification based on the epilepsy-related variables. The second function will classify almost the children left after function 1 has been applied.

Table 5. Canonical discriminant functions

\begin{tabular}{lcrrr}
\hline Test of function(s) & Wilks' Lambda & Chi-square & \multicolumn{1}{c}{ d.f. } & \multicolumn{1}{c}{ Sig. } \\
\hline 1 through 2 & .671 & 38.684 & 14 & $<.001$ \\
2 & .945 & 5.462 & 6 & .486 \\
\hline
\end{tabular}

As visualized in Fig. 1, the first function mainly distinguishes SLRE from the other two options in the classification, IGE and CLRE. The figure shows the SLRE centroid to score higher on function 1 than IGE and CLRE do (a higher score on the x-axis). This is mainly explained by a higher IEA and a longer duration of the epilepsy. Also, it is clear that the IGE centroid scores lowest on both functions, and CLRE is rather inbetween in this respect (Fig. 1). With a higher IQ, later age at onset and less long duration of epilepsy, CLRE appears to be characterized by more optimistic values of the variables that built these functions.
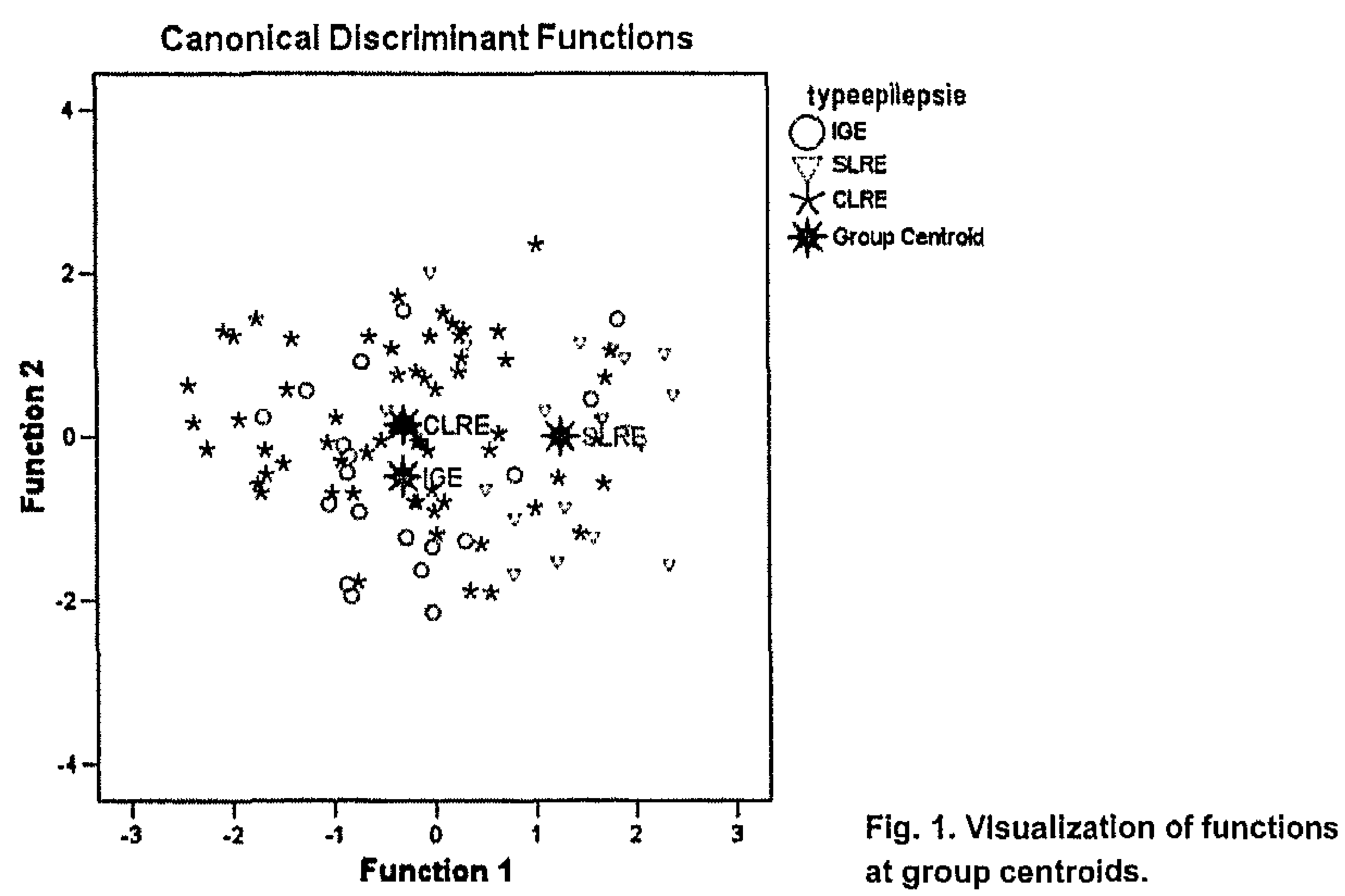
Table 6. Comparison of clinical and constructed classifications

\begin{tabular}{llccccc}
\hline & \multirow{2}{*}{ Type of epilepsy } & \multicolumn{2}{l}{ Constructed classification } & \multicolumn{2}{l}{ Total } \\
& & IGE & SLRE & CLRE & \\
\hline Clinical classification (\%) & IGE & 57.9 & 15.8 & 26.3 & 100.0 \\
& SLRE & 14.3 & 71.4 & 14.3 & 100.0 \\
& CLRE & 31.7 & 19.0 & 49.2 & 100.0 \\
\hline
\end{tabular}

The $55.3 \%$ of original grouped cases correctly classified.

The next step is to compare the constructed classification, based on these functions (as a combination of the aforementioned epilepsy-related variables), with the original clinical classification into types of epilepsy, i.e. IGE, CLRE and SLRE. This shows (Table 6 ) that in total $55.3 \%$ of the cases are correctly classified (there is $55.3 \%$ overlap between the constructed classification and the clinical classification). More specifically, these results are $57.9 \%$ for IGE, $71.4 \%$ for SLRE and $49.2 \%$ for CLRE.

Of the children originally classified as CLRE, $19.0 \%$ were classified as SLRE by the constructed functions, and $49.2 \%$ as IGE. Of the children originally classified as IGE, $26.3 \%$ were classified as CLRE by these functions, and $15.8 \%$ as SLRE. Of the children classified as SLRE originally $14.3 \%$ were classified CLRE and $14.3 \%$ were classified IGE by the constructed functions.

\section{Discussion}

Our study confirms that three epilepsy groups are distinguishable from each other, by means of weighing the characteristics defining their epilepsy. However, the original clinical classification, based on the existing clinical knowledge using the ILAE proposal ${ }^{1}$, differed from the classification based on the 'functions' combining sets of epilepsy-related variables. For SLRE, the two classifications matched very well. This means that the epilepsy characteristics are in line with a classification based on aetiology. The children with SLRE in our cohort differed significantly from the other children by their high IEA and longer duration of their epilepsy. Likewise, the two classifications of IGE corresponded nicely. On the contrary, CLRE remains a group rather difficult to classify. Over half of the children with CLRE were classified as IGE or SLRE by the classification constructed with the epilepsy characteristics.

The overlap suggested between categories or epilepsy types concurs with the assumption that CLRE is 'presumed to be symptomatic'. ${ }^{1}$ Similar to SLRE, the category CLRE can be assumed to be compiled of several subgroups. This would explain the heterogeneity of the cohorts studied so far. ${ }^{14}$ As such, it is not strange that CLRE has been grouped with SLRE in cohort studies before. Nevertheless, there is a need to better describe and delineate these subgroups. It is plausible that children now diagnosed as having CLRE, in the future will be diagnosed as having SLRE, as knowledge and potentials of neuroimaging expand. However, it is just as likely that a subgroup of this population will be recognized as having similar risk factors and course of 
the epilepsy, and so forth be diagnosed with a yet to be described syndrome diagnosis. Most likely this diagnosis would be classified as an idiopathic localization related epilepsy (ILRE). Indeed our data suggest a nearness to the idiopathic epilepsies. A focus found with EEG recording, as well as a partial semiology of the seizures of course indicate an ILRE rather than an IGE.

Surprisingly, the overlap between CLRE and IGE seems larger than between CLRE and SLRE. Most probably this can be explained by a selection bias. We attempted to validate the existing ILAE classification within the population of an epilepsy outpatient clinic in which more complicated epilepsies are included that generally cause confusion in daily epilepsy care. ${ }^{1}$

The children referred to our centre do not in majority represent 'typical' cases. When for example the IGE group would have consisted only of children with benign absence epilepsy, and the SLRE group of children with refractory epilepsy as a result of post-infarction hemiplegia, the differences between the groups would have been more distinct. CLRE would have fit in-between the two other cohorts, with slight overlap with the SLRE group. Importantly, our results reflect the heterogeneity of CLRE in more complex situations of medical decision making, i.e. in the case of overlap of symptoms.

CLRE is difficult to classify based on the epilepsy-related variables, which are essentially the only variables one has when interpreting a cryptogenic partial epilepsy in a child. However, CLRE does not simply fit into any other class of epilepsy. Therefore, it is not justified to investigate cohorts of CLRE, mixed with either SLRE or IGE as is sometimes done.

A more thorough investigation into epilepsy-related variables may help us distinguishing subgroups of patients with CLRE and find factors that may help us determining prognosis or preferred care.

We believe that this is a more profitable approach than simple labelling all these children as 'probably symptomatic', i.e. suggesting an underlying aetiology that may be never found.

\section{Acknowledgements}

We would like to thank Lotte Nieuwenhuis (neurologist) for the participation in the discussions on diagnostics of individual cases and diagnostic theory. 


\section{References}

1. Proposal for revised classification of epilepsies and epileptic syndromes. Commission on Classification and Terminology of the International League Against Epilepsy. Epilepsia 1989;30(4):389-99.

2. Berg, J. Lin, N. Ebrahimi, F.M. Testa, S.R. Levy and S. Shinnar, Modeling remission and relapse in pediatric epilepsy: application of a Markov process, Epilepsy Res 60 (1) (2004), pp. 31-40.

3. Waaler, B.H. Blom, H. Skeidsvoll and A. Mykletun, Prevalence, classification, and severity of epilepsy in children in western Norway, Epilepsia 41 (7) (2000), pp. 802-810.

4. Eriksson and M.J. Koivikko, Prevalence, classification, and severity of epilepsy and epileptic syndromes in children, Epilepsia 38 (12) (1997), pp. 1275-1282.

5. Berg, S.R. Levy, F.M. Testa and S. Shinnar, Classification of childhood epilepsy syndromes in newly diagnosed epilepsy: interrater agreement and reasons for disagreement, Epilepsia 40 (4) (1999), pp. 439-444.

6. Berg, S. Shinnar, S.R. Levy, F.M. Testa, S. Smith-Rapaport and B. Beckerman, How well can epilepsy syndromes be identified at diagnosis? A reassessment 2 years after initial diagnosis, Epilepsia 41 (10) (2000), pp. 1269-1275.

7. Kellinghaus, T. Loddenkemper, I.M. Najm, E. Wyllie, T. Lineweaver and D.R. Nair et al., Specific epileptic syndromes are rare even in tertiary epilepsy centers: a patient-oriented approach to epilepsy classification, Epilepsia 45 (3) (2004), pp. 268-275.

8. Berg, S. Shinnar, S.R. Levy, F.M. Testa, S. Smith-Rapaport and B. Beckerman et al, Two-year remission and subsequent relapse in children with newly diagnosed epilepsy, Epilepsia 42 (12) (2001), pp. 1553-1562.

9. Ohta, Y. Ohtsuka, T. Tsuda and E. Oka, Prognosis after withdrawal of antiepileptic drugs in childhoodonset cryptogenic localization-related epilepsies, Brain Dev 26 (1) (2004), pp. 19-25.

10. Sander, Some aspects of prognosis in the epilepsies: a review, Epilepsia 34 (6) (1993), pp. 1007-1016.

11. Aldenkamp and J. Arends, The relative influence of epileptic EEG discharges, short nonconvulsive seizures, and type of epilepsy on cognitive function, Epilepsia 45 (1) (2004), pp. 54-63.

12. Aldenkamp and J. Arends, Effects of epileptiform EEG discharges on cognitive function: is the concept of "transient cognitive impairment" still valid?, Epilepsy Behav 5 (Suppl. 1) (2004), pp. S25-S34.

13. Camfield and P. Camfield, Predicting the outcome of childhood epilepsy: a population-based study yielding a simple scoring system, J Pedlatr 122 (1993), pp. 861-868.

14. Reijs, S.G. Van Mil, M.H. Van Hall, J.B. Arends, J.W. Weber and W.O. Renier et al., Cryptogenic localization-related epilepsy with childhood onset: the problem of definition and prognosis, Epilepsy Behav 8 (4) (2006), pp. 693-702.

15. Sillanpää and D. Schmidt, Prognosis of seizure recurrence after stopping antiepileptic drugs in seizurefree patients: a long-term population-based study of childhood-onset epilepsy, Epilepsy Behav 8 (4) (2006), pp. 713-719.

16. Ohtsuka, H. Yoshinaga and K. Kobayashi, Refractory childhood epilepsy and factors relaled to refractoriness, Epllepsia 41 (Suppl. 9) (2000), pp. 14-17.

17. Shinnar, A.T. Berg, S.L. Moshe, C. O'Dell, M. Alemany and D. Newstein et al., The risk of seizure recurrence after a first unprovoked afebrile seizure in childhood: an extended follow-up, Pediatrics 98 (2 Pt 1) (1996), pp. 216-225.

18. R Guerrini, Brain maturation and the evolution of epilepsy syndromes, Epilepsia (2006), p. 255 [7th European Congress on Epileptology].

19. Proposal for revised clinical and electroencephalographic classification of epileptic selzures. From the Commission on Classification and Terminology of the International League Against Epilepsy. Epilepsia 1981 22(4):489-501. 


\title{
Chapter Three
}

\author{
Cryptogenic localization related \\ epilepsy in children from a tertiary \\ outpatient clinic:
}

Is neurological and neuropsychological outcome predictable? 


\begin{abstract}
Objectives Up to one-third of the children with epilepsy are diagnosed with cryptogenic localization related epilepsy (CLRE). As yet, there is a lack of studies that specify the short- and long-term prognosis for this group. In this study, we systematically established neurological outcome (represented by seizure frequency) as well as neuropsychological outcome in a cohort of 68 children with CLRE who had been referred to our tertiary outpatient clinic. Also, we analysed correlations with risk and prognostic factors.
\end{abstract}

Patients and methods A systematic cross-sectional open clinical and non-randomized design was used including 68 children admitted to our epilepsy centre in a child neurological programme between January 1999 and December 2004. A model was defined, distinguishing risk factors with a potential effect on epileptogenesis (history of febrile seizures, family history of epilepsy, history of early mild development delay and serious diagnostic delay) and prognostic factors, with a potential effect on the course of the epilepsy (neurological symptoms or soft signs, age at onset, duration of epilepsy, seizure type, percentage of time with epileptiform activity, localization of epileptiform activity, treatment history and treatment duration). Seizure frequency was used as the primary outcome variable, whereas three neuropsychological outcomes (IQ, psychomotor delay and educational delay) were used as secondary outcome variables.

Results The children experienced a broad range of seizure types with the 'absencelike' complex partial seizure as the most commonly occurring seizure type. Almost half of the children of the study sample had a high seizure frequency. They experienced several seizures per month, week or even daily seizures. Also a substantial impact on neuropsychological outcome was observed. Mean full scale IQ was 87.7, mean academic delay was almost 1 school year and 27 children showed psychomotor delay on the Movement ABC. Only 'having more than one seizure type' showed a prognostic value for seizure frequency, and no factors were found to be correlated with the secondary outcome measures. None of the risk factors show a differential impact on seizure outcome.

Conclusion CLRE has a non-predictable course; clinical variability is high and prognosis in many children with CLRE is obscure. Having more than one seizure type was the only factor correlated to seizure frequency. Further longitudinal studies are needed.

Published as:

Reijs RP, van Mil SG, Arends JB, van Hall MH, Weber JW, Renier WO, Aldenkamp AP. Cryptogenic localization related epilepsy in children from a tertiary outpatient clinic: is neurological and neuropsychological outcome predictable? Clin Neurol Neurosurg. 2007 Jun; 109(5):422-30. 


\section{Introduction}

Up to one-third of the children with epilepsy are diagnosed with cryptogenic localization related epilepsy (CLRE). ${ }^{1-3}$ Their epileptic seizures have a localized onset, and the epilepsy is believed to be a symptom of an unknown underlying disorder. Nevertheless, the aetiology remains unclear. This leads to a very diverse population, which is difficult to capture for research purposes.

As yet, there is a lack of studies that specify the short- and long-term prognosis for this group. Hence, after diagnosis children and parents await a period of uncertainty. Usually the prognosis is assumed to be somewhere between the benign course of many idiopathic epilepsies, and the more malignant course of most symptomatic epilepsies. Camfield and Camfield find less than half of their children with CLRE to have a so called 'smooth sailing epilepsy', a benign course with easily attained and lasting seizure control. ${ }^{5}$ Berg et al. suggest the existence of a wave-like pattern regarding seizure control, with recurring remissions and relapses. ${ }^{1}$ Apparently seizure outcome is more uncertain and CLRE may be more difficult to treat than originally suggested.

Furthermore, childhood epilepsies may be accompanied by secondary problems that often limit future possibilities such as learning disorders and behavioural disturbances. ${ }^{6}$ For CLRE the impact on such developmental functions has not been established, although some studies suggest a serious impact of CLRE on cognition and behaviour, at least in some subgroups. ${ }^{7}$

In the outpatient department of our epilepsy centre, we see children with epilepsy of all types. Through a clinical programme, we offer children of school going age a multidisciplinary view on their epilepsy and every part of their condition that might be influenced by their epilepsy, such as behaviour and achievements in school. We became aware of a lack of frame work with regards to the children that were diagnosed with CLRE, and what to expect for their outcome. As there is such a large clinical variety in this population, an exploratory study appears the most logical first approach.

In this study, the aim is to establish neurological outcome (represented by seizure frequency) and neuropsychological outcome (represented by $1 \mathrm{Q}$, psychomotor delay and educational delay) in a cohort of children diagnosed as suffering from CLRE and referred to our tertiary outpatient clinic. Furthermore we analysed correlations with risk and prognostic factors. 


\section{Patients and methods}

\section{Design}

A systematic cross-sectional open clinical and non-randomized design was used.

Subject selection

The children and adolescents, whose data were analyzed in this study, were referred to our epilepsy centre for a child neurological programme. In this programme, children and adolescents are admitted for 3 days, to facilitate a thorough analysis of their physical and cognitive state with regards to their epilepsy. During these 3 days, the child is observed by specialized nurses, undergoes EEG-registration, is examined by a neurologist and a physical therapist. Furthermore a neuropsychological test battery is administered, and an analysis of the educational achievements is performed by a child neuropsychologist.

Patients were referred by their paediatricians, neurologists, and sometimes by their general physicians. The reason for referral was most often to obtain a full view on the state of the epilepsy, the bearing the epilepsy has on the life of the child and a second opinion on the chosen treatment regimen.

Through discussion of all these outcomes, a multidisciplinary team decides whether the current epilepsy management for the child is sufficient, or recommends adjustments or further diagnostics:

- Inclusion criteria for this study: Age at admission 6-16 years, neuroimaging (CT, MRI) without abnormality, diagnosis of CLRE, which was made or confirmed by a (child) neurologist at our epilepsy centre using the ILAE classification (1985, \#4), i.e. localization related epilepsy presumed to be symptomatic, but without a known aetiology. ${ }^{8}$

- Exclusion criteria: $1 Q<70$, absence of neuroimaging, signs or symptoms of brain pathology other than epileptic seizures, other neurological disease or any known psychiatric disorder.

\section{Assessment procedures}

A standardized protocol of assessments was followed during a 3 day admission to our epilepsy centre.

History taking

Standardized extensive history taking of patients and their parents.

The following variables were recorded:

- age;

- sex;

- age at onset;

- age at diagnosis; 
- diagnostic delay (the period between seizure onset and epilepsy diagnosis);

- duration of the epilepsy;

- seizure type;

- number of seizure types;

- current seizure frequency for each seizure type;

- a history of status epilepticus;

- a history of febrile seizures;

- signs of mild early psychomotor delay (i.e. previous follow-up of the child because of doubts regarding child development without needing an intervention, or use of physical therapy or language therapy);

- family history of epilepsy;

- anti-epileptic drugs and dosage;

- treatment history (current AED, treatment duration and number of anti-epileptic drugs tried before deciding to the current regimen).

All these items were checked on inspection of the patient files.

Seizure types were classified using the ILAE classification. Subsequently, the seizure types were categorized as follows:

a. Simple partial seizures;

b. Complex partial seizures, which includes seizures with a simple partial onset;

c. Secondary generalized seizures, which includes both seizures with a partial onset, as well as seizures that appear immediately generalized, such as tonic and astatic seizures.

Whenever a child had more than one seizure type, the primary seizure type was determined by the neurologists. This was based on the severity of the seizures, due to either a high frequency or a severe semiology.

Seizure frequency is recorded in three categories: (a) seizure free, for at least 1 year; (b) low seizure frequency, ranging from one seizure in the previous year up to one seizure per month; (c) high seizure frequency, ranging from more than one seizure per month to daily seizures.

Neurological physical examination

The following variable was recorded:

- Presence of neurological signs or symptoms.

Focal neurological disorder would be considered a reason for exclusion. Soft signs, more specifically immaturity of movements, hyper- or hypoactive tendon reflexes and difficulty with left right discrimination, were accepted with regards to the diagnosis of CLRE.

\section{Neuropsychological examination}

The following variables were recorded:

- Full scale IQ (Wechsler Intelligence Scale for Children-Revised for The Netherlands, WISC-RN);

Information was obtained on type of education attained by the child;

- Educational delay. 
For this variable of delay a school achievement test comparable to the Wide-Range Achievement Test (WRAT) in English-speaking countries was administered [9]. Three variables of delay (regarding "words", "sentences" and "arithmetic") were calculated into one variable of general academic delay, and rated as no delay, mild or serious delay. Ten months delay equals 1 school year. When a child is delayed no more than 5 months in any domain, this is regarded a mild delay. When a child is delayed more than 5 months in two domains, or more than 10 months in at least one domain, this is regarded serious delay.

\section{EEG recording}

The type of EEG to be recorded was determined by a Board-certified clinical neurophysiologist specialized in epilepsy. The standard choice was a $30 \mathrm{~min}$ routine EEG; whenever there were questions regarding the influence of further interictal epileptiform activity on the state of the child, a routine EEG combined with $24 \mathrm{~h}$ ambulatory EEG was performed. Other types of EEG were applied whenever there were additional questions to be answered, within or besides the admission to our programme. Thirty-seven children had a $24 \mathrm{~h}$ ambulatory EEG (32 channels) performed, in 25 children a $30 \mathrm{~min}$ routine EEG, three times an EEG with simultaneous neuropsychological examination was done, twice EEG with videomonitoring, and once a polysomnography. A subanalysis was performed to compare the findings of the $24 \mathrm{~h} E \mathrm{EG}$ recordings to the $30 \mathrm{~min}$ routine EEG recordings. No differences were found $(p=0.726)$.

The following variables were collected:

- Presence and percentage of time with interictal epileptic activity (IEA) during wakefulness (no epileptic activity or less than $1 \%$ of recording time, from $1 \%$ up to $5 \%$ of recording time, and more than $5 \%$ of recording time);

- Localization of the IEA (focal or multifocal; temporal or extratemporal; left, right or both hemispheres).

Interictal epileptiform activity is defined as follows: "spikes, not differentiated as focal or regional, nor as rythmic, non-rythmic or intermittent"

The localization of the IEA is summarized in Table 1.

\section{Psychomotor screening}

The motor development was assessed using the Movement Assessment Battery for Children (Movement ABC). ${ }^{10}$ The cut-off score was set at the 15 th percentile, a score below the 15 th percentile indicates delay of motor development.

\section{Statistical analysis}

Seizure frequency was considered as the primary outcome measure.

$I Q$, educational or psychomotor delay were regarded as secondary 'developmental' outcomes. 


\begin{tabular}{|c|c|}
\hline Interictal Epileptiform Activity on EEG (IEA) & Number of children \\
\hline No IEA & Twenty-four children \\
\hline \multicolumn{2}{|l|}{ IEA, $<1 \%$ or $>1 \%$ of the time } \\
\hline Focal IEA & Thirteen children \\
\hline \multirow[t]{2}{*}{ Temporal IEA } & Five left \\
\hline & One right \\
\hline \multirow[t]{4}{*}{ Extratemporal IEA } & Five left \\
\hline & One right \\
\hline & One both \\
\hline & One non-lateralized \\
\hline Multifocal IEA & Thirty-one children \\
\hline \multirow[t]{2}{*}{ Temporal IEA } & One left \\
\hline & Two bilateral \\
\hline \multirow[t]{4}{*}{ Extratemporal IEA } & One left \\
\hline & One right \\
\hline & Seventeen both hemispheres \\
\hline & One non-lateralized \\
\hline \multirow[t]{3}{*}{ Both temporal and extratemporal IEA } & Two left \\
\hline & One right \\
\hline & Five both hemispheres \\
\hline
\end{tabular}

Age at seizure onset, duration of epilepsy, seizure type, neurological signs and symptoms and/or soft signs, percentage of time with epileptiform activity on the EEG, the localization of the epileptiform activity on EEG, and treatment history (current AED, treatment duration and number of AED tried) are referred to as prognostic factors. We hypothesize these factors to characterize the epilepsy, and therefore have predictive value for the outcome. A history of febrile seizures, family history of epilepsy and history of early mild developmental delay were considered risk factors that may have had an influence on the process of epileptogenesis. A somewhat separate variable is diagnostic delay, which equals postponement of treatment. Even though there is an ongoing debate concerning the influence of postponement of treatment on the course of the epilepsy, it might certainly have an influence on development of the child, reflected in the secondary outcomes. ${ }^{11,12}$

When studying the secondary outcome measures, seizure frequency is considered an additional prognostic factor. 
This results in the following analysis model (Fig. 1).

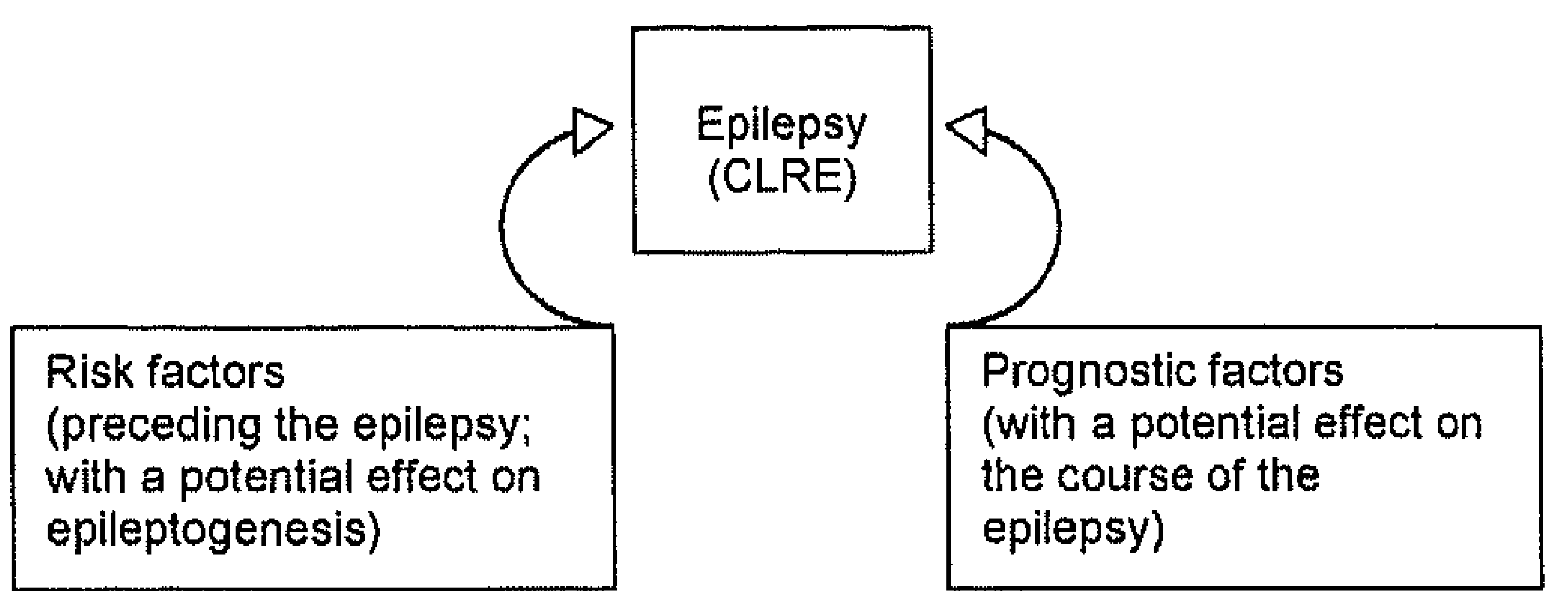

- history of febrile seizures
- family history of epilepsy
- history of early mild
developmental delay
- diagnostic delay

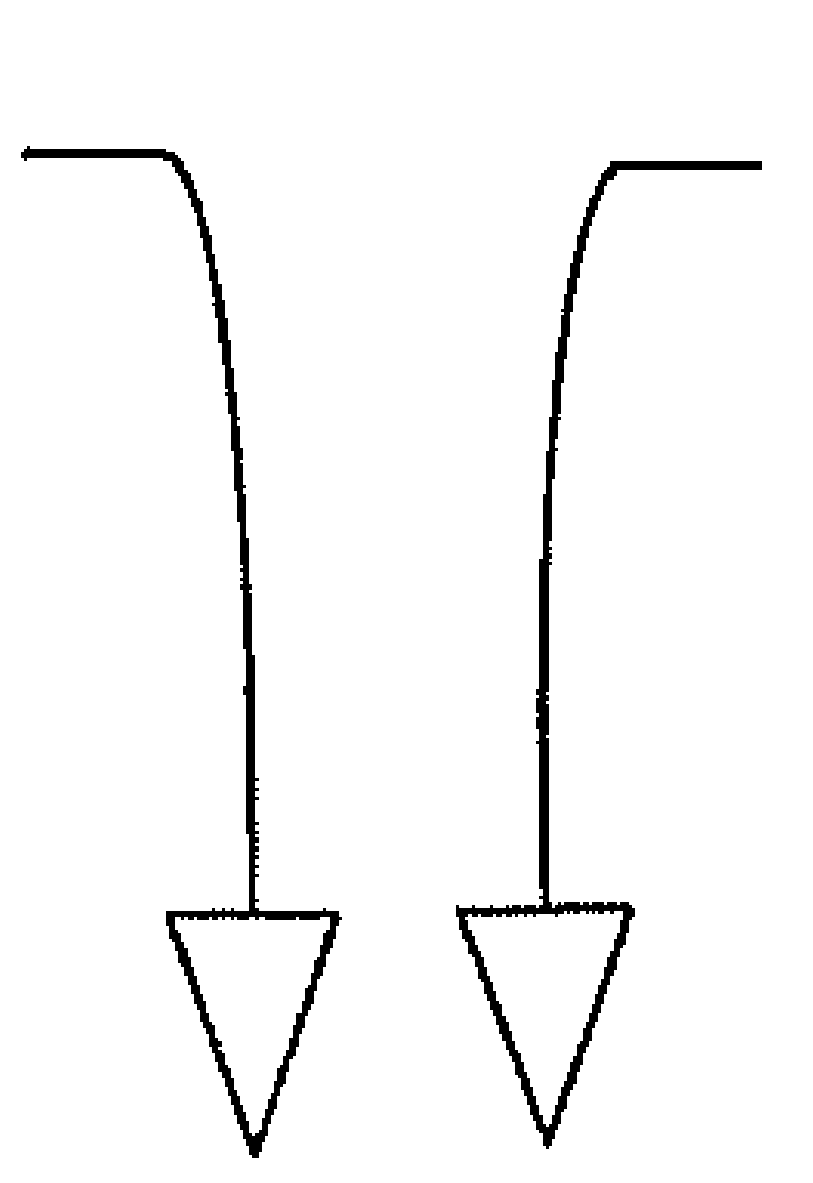

- age at seizure onset - duration of epilepsy - seizure type

- neurological signs and symptoms

$-\%$ of time with spikes on

EEG recording

- localization of spikes

- treatment history

\section{Outcome:}

1. Seizure frequency

2. IQ, educational delay, psychomotor delay

Fig. 1. Analysis model.

The data were collected on record forms, and entered into a database. The Statistical Package for Social Sciences (SPSS), Version 11.0 for Windows was used to process these data. Firstly, we analysed the correlations between the prognostic variables and the primary and secondary outcome variables using Pearson correlation.

Secondly, we compared subgroups defined by the risk factors (Fig. 1) with the corresponding remainder of the cohort. Ranked and ordinal distributions were compared using $\mathrm{Chi}^{2}$ and Fisher's exact test where appropriate, replaced by the Mann-Whitney $U$ whenever groups were too small or the assumptions for $\mathrm{Chi}^{2}$ were not met. For comparison of the distributions of $I Q$ within the high and low risk groups, the t-tests for equality of means was used.

We did not expect to find correlations strong and significant enough to allow for multivariate analysis.

\section{Patients}

The clinical and demographical characteristics of the study group are summarized in Table 2. The study group is presented more elaborately in Section 3. 
In all children neuroimaging was done, and no abnormalities were found. In 62 children neuroimaging was done using MRI, in 6 children CT was used.

\section{Power analysis}

To compare high risk groups with low risk groups (i.e. the rest of the cohort; see Fig. 1 for risk factors), we require the low risk group to be larger than 25 subjects. Therefore, the total sample size was set at $>60$ patients.

\begin{tabular}{|c|c|}
\hline$N$ & 68 \\
\hline$m: f$ & $40: 28$ \\
\hline Family history of epilepsy & 17 \\
\hline History of febrile seizures & 11 \\
\hline History of early mild developmental delay & 18 \\
\hline Serious diagnostic delay ${ }^{a}$ & 13 (delay $29-133$ months) \\
\hline Age at assessment & 123 months (73-191; S.D. 28.53) \\
\hline Age at onset & 74 months (0-165; S.D. 44.73 ) \\
\hline Duration of epilepsy & 49 months (0-145; S.D. 36.44$)$ \\
\hline Age at diagnosis & 91 months (0-171; S.D. 40.89) \\
\hline Duration since diagnosis ${ }^{b}$ & 32 months (0-106; S.D. 28.54$)$ \\
\hline Status epilepticus in history & 5 \\
\hline Soft signs during neurological examination & 15 \\
\hline \multicolumn{2}{|l|}{ Seizure type } \\
\hline Simple partial seizures & 7 \\
\hline Absence-like complex partial sz & 32 \\
\hline Complex partial sz, not absence-ilke & 19 \\
\hline (Secondary) generalized seizures & 10 \\
\hline More than one seizure type & 17 \\
\hline \multicolumn{2}{|l|}{ Epileptiform activity on EEG recording } \\
\hline No epileptiform activity & 24 \\
\hline$<1 \%$ of the time & 23 \\
\hline$>1 \%$ of the time & 20 \\
\hline \multicolumn{2}{|l|}{ Spatial characteristics of epileptiform activityc } \\
\hline Focal activity & 13 \\
\hline Multifocal activity & 31 \\
\hline Temporal focus & 8 \\
\hline Extratemporal focus & 28 \\
\hline Both temporal and extratemporal & 8 \\
\hline One hernisphere & 17 (13 left, 4 right hemisphere) \\
\hline Both hemispheres & 25 \\
\hline
\end{tabular}


No AED treatment

Monotherapy

Polytherapy

First AED

Second AED

Third or more AED $9^{d}$

44

18 VPA (mean daily dose $474 \mathrm{mg}$ )

$14 \mathrm{CBZ}$ (mean daily dose $627 \mathrm{mg}$ )

7 LMT (mean daily dose $164 \mathrm{mg}$ )

3 ETX (mean daily dose $708 \mathrm{mg}$ )

2 OXC (mean daily dose $900 \mathrm{mg}$ )

15

9

33

18

More than 12 months between onset and diagnosis of epilepsy.

' In all children AED treatment had been started at diagnosis, therefore 'duration since diagnosis' equals 'duration of treatment' for children on AED at time of assessment.

${ }^{c}$ More specific EEG data are displayed in Table 3.

"All children had been treated with AED before.

\section{Results}

Patients experienced a broad range of seizure types (see also Fig. 2).

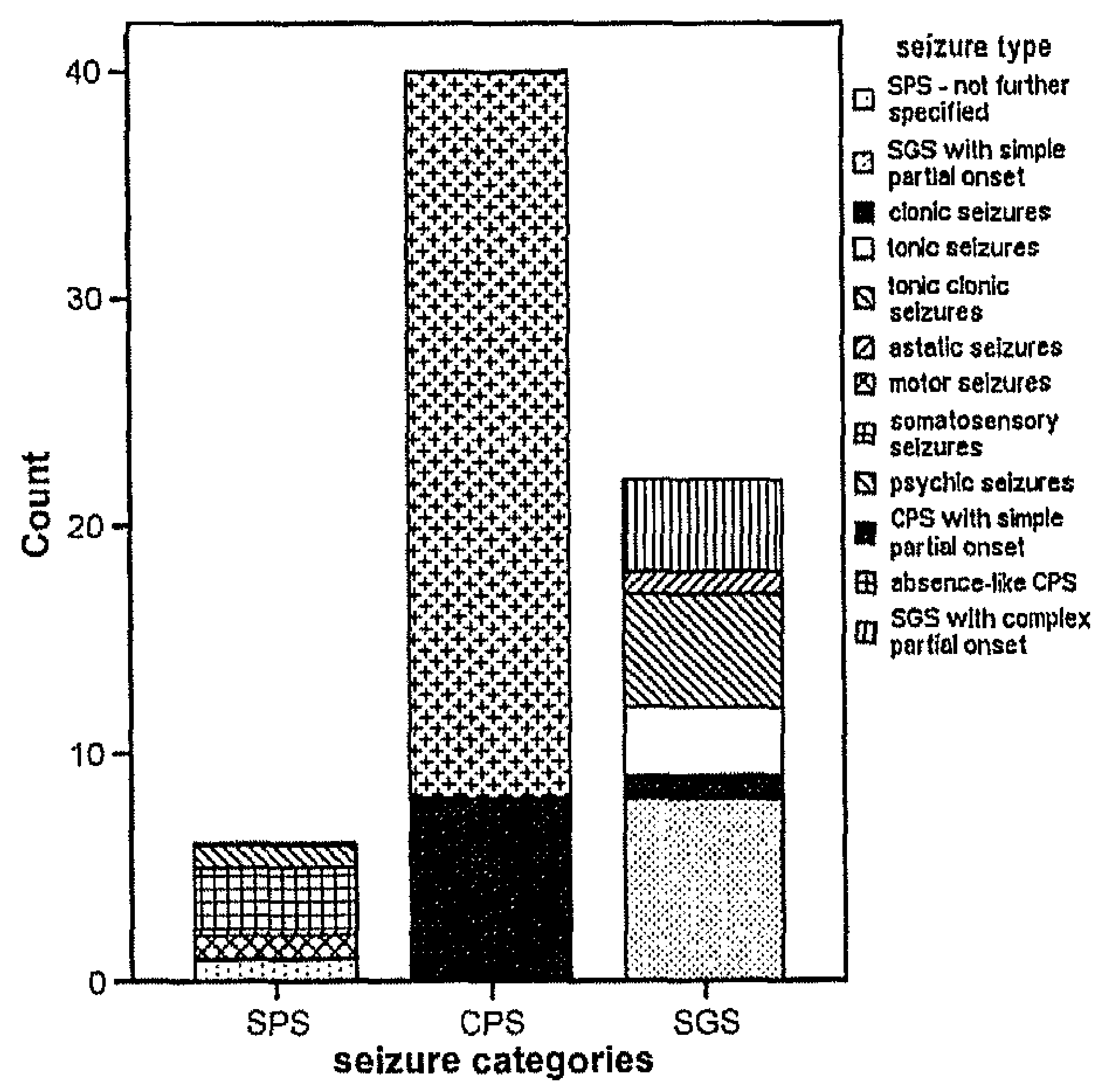

Fig. 2. Seizure types within the categories Simple Partial Seizures, Complex Partial Selzures, Secondary Generalized Seizures 
Six children had simple partial seizures. They experienced motor seizures and somatosensory seizures. Three children had daily seizures, three children had monthly seizures (6-12 seizures in the last 6 months). Three children also had a second seizure type, complex partial seizures or simple partial seizures generalizing to complex partial seizures.

Three children had a high seizure frequency and three had a low seizure frequency. The child with two seizure types had a low seizure frequency for both seizure types. Only one child showed epileptic activity on the EEG, more than $5 \%$ of the time. He had a high seizure frequency.

Forty children were categorized as having complex partial seizures (CPS).

In eight children the seizures had a simple partial onset, and generalized to complex partial seizures. The other 32 children had CPSs that resembled absences, also called absence-like CPSs. A total of 10 children had a second seizure type, either tonic clonic seizures, myoclonic seizures, simple partial seizures or another type of complex partial seizures. Of these 10 , only 1 child was seizure free for this second seizure type; other than that they all experienced both first and second seizure type seizures at a low or high frequency. Three children had spikes in their EEG recording, $1-5 \%$ of the recording time.

Of the 25 children with only absence-like CPSs, only 3 showed spikes on the EEG for more than $5 \%$ of the time and 3 showed spikes for $1-5 \%$ of the time; none of them were seizure free. In five of the six children the epileptic activity was multifocal.

Twenty-three children had a high seizure frequency, eight children had a low seizure frequency and only nine were seizure free.

Twenty-two children had secondary generalized seizures, of which 12 children had seizures with a clear partial onset. Three children had more than one seizure type, two had other partial seizures without further generalization, one had astatic seizures. These three all had a high seizure frequency, as did only one other child. One of the other children was seizure free, whereas the rest of this group had a low seizure frequency. Three children showed epileptic activity on EEG; none of them had more than one seizure type, none of them were seizure free.

Ten children had seizures that immediately appeared as generalized. Five children had more than one seizure type, which in all cases were seizures with a partial semiology without further generalization. Three children were seizure free, three had a low seizure frequency and four had a high seizure frequency. Only two children showed epileptic activity, for $1-5 \%$ of the time and multifocal.

The seizure frequencies as well as the secondary outcomes are summarized in Table 3. Thirteen children had been seizure free for at least 1 year. Twenty-one children had a low seizure frequency, ranging from one seizure in the previous year up to one seizure per month. As many as 34 children, almost half of the study sample, had a high seizure frequency. They experienced several seizures per month, week or even daily seizures (Fig. 3 ). 
Table 3. Primary and secondary outcome

\begin{tabular}{ll}
\hline Seizure frequency & \\
Seizure free & 13 \\
Low frequency & \\
High frequency $^{b}$ & 21
\end{tabular}

M-ABC $<15 \%$ (abnormal) $\quad 27$

Wechsler Full scale IQ $\quad 87.7(70-127$, S.D. 12.00)

$\begin{array}{lr}\text { Academic delay } & \\ \text { No delay } & 8 \\ \text { Mild delay }^{\mathrm{c}} & 9 \\ \text { Serious delay }^{\mathrm{d}} & 38\end{array}$

${ }^{a}$ Up to one seizure per month.

${ }^{b}$ At least one seizure per month.

${ }^{\mathrm{C}}$ No more than 5 months delay per academic domain.

dMore than 5 months delay in at least two domains, or more than 10 months delay in an academic domain.

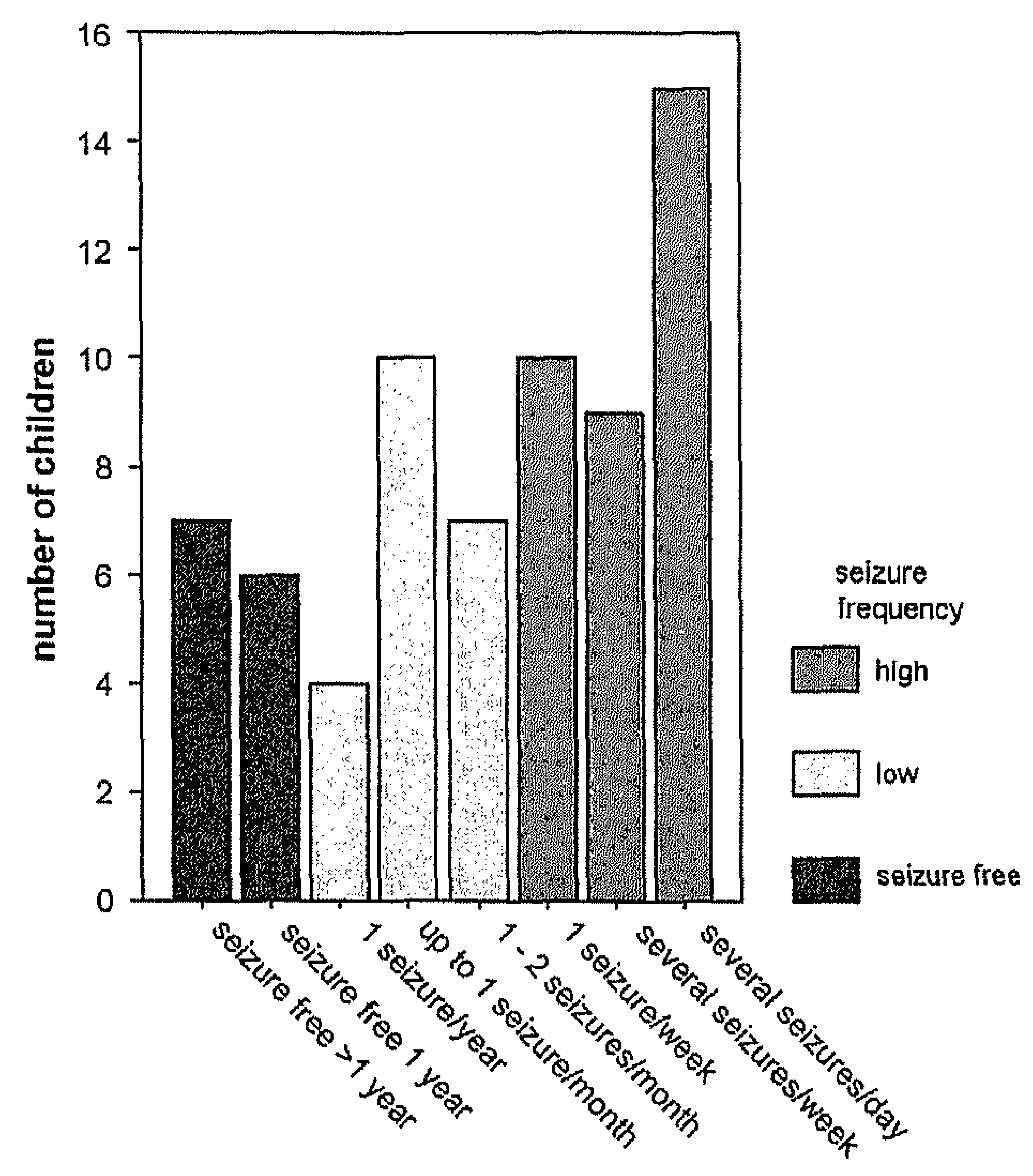

Fig. 3. Distribution of seizure frequencies within each category. 
The mean full scale IQ was 87.7 (range 70-127; S.D. 12.00). Fifty-six children $(82.5 \%)$ attended regular education, eleven children attended special education, such as a school for children with language problems.

The mean educational delay was 8.42 months (S.D. 13.8) for reading words, 9.96 months (S.D. 14.8) for reading sentences and 6.89 months (S.D. 15.4) for arithmetic (10 months equals 1 school year). Thus the average delay was approximately 1 school year. These three variables of delay were calculated into one variable of general academic delay, rated as no delay, mild or serious delay. Only 8 children had no delay, 9 children had mild delay and 38 children had serious delay in school.

Twenty-seven children had an age-adjusted score below the 15th percentile for the $M A B C$, indicating delay of psychomotor development.

\section{Prognostic variables}

To quantify the influence of the prognostic factors on the primary outcome (seizure frequency), their correlations with seizure frequency were analysed. The only prognostic factor that appeared to be significantly correlated to seizure frequency, was whether the child had more than one seizure type (Table 4).

Furthermore relationships were inspected regarding secondary outcomes: academic delay, IQ and psychomotor delay and the prognostic epilepsy variables:

Academic delay: The cohort was divided into three groups: no delay, mild delay and serious delay, as described before. No significant correlation was found between academic delay and any of the prognostic factors (Table 5).

Intelligence level (Wechsler Full scale IQ): No significant correlation was found between $I Q$ and any of the prognostic factors (Table 6).

Psychomotor delay (Movement $A B C$ ): The correlations between the prognostic factors and psychomotor delay are summarized in Table 7. A significant correlation was found between the occurrence of 'soft signs' $(r=-0.306, p=0.016)$ in the neurological examination and a motor delay as measured by application of the Movement $A B C$. The registration of 'soft signs' is a clinical observation, whereas motor delay is registered using a more objective and validated assessment procedure; both obviously focus on motor development.

\section{Risk factors}

The next step in analyzing our study sample was to identify the risk groups and compare these to the rest of the cohort. For each risk factor the effect on the primary outcome variable (seizure frequency) was inspected as well as the effect on the secondary developmental outcomes (IQ, educational delay and psychomotor delay). The results are summarized in Table 8. 
Table 4. Correlations between prognostic factors and seizure frequency

\begin{tabular}{lcc}
\hline & $R$ & $p$ \\
\hline Age at seizure onset & -0.830 & 0.513 \\
Duration of epilepsy & -0.177 & 0.151 \\
Seizure type & 0.126 & 0.307 \\
More than one seizure type & 0.253 & 0.037 \\
Occurrence of soft signs & 0.111 & 0.368 \\
Spikes on EEG & 0.081 & 0.510 \\
Treatment history & -0.060 & 0.678 \\
Current treatment & 0.126 & 0.304 \\
\hline
\end{tabular}

Table 5. Correlations between prognostic factors and academic delay

\begin{tabular}{lrc}
\hline & $\mathrm{R}$ & $\mathrm{p}$ \\
\hline Age at seizure onset & 0.200 & 0.158 \\
Duration of epilepsy & -0.550 & 0.700 \\
Seizure type & 0.186 & 0.174 \\
More than one seizure type & -0.093 & 0.499 \\
Seizure frequency & -0.168 & 0.221 \\
Occurrence of soft signs & -0.036 & 0.797 \\
Spikes on EEG & 0.069 & 0.619 \\
Treatment history & 0.173 & 0.207 \\
Current treatment & 0.104 & 0.451 \\
\hline
\end{tabular}

Table 6. Correlations between prognostic factors and IQ

\begin{tabular}{lrc}
\hline & $\mathrm{R}$ & $\mathrm{P}$ \\
\hline Age at seizure onset & 0.167 & 0.186 \\
Duration of epilepsy & -0.020 & 0.876 \\
Seizure type & 0.029 & 0.813 \\
More than one seizure type & 0.061 & 0.620 \\
Seizure frequency & -0.132 & 0.284 \\
Occurrence of soft signs & 0.127 & 0.300 \\
Spikes on EEG & -0.129 & 0.293 \\
Treatment history & -0.072 & 0.560 \\
Current treatment & 0.113 & 0.359
\end{tabular}

Table 7. Correlations between prognostic factors and motor development

\begin{tabular}{lcc}
\hline & $\mathrm{R}$ & $\mathrm{p}$ \\
\hline Age at seizure onset & 0.009 & 0.950 \\
Duration of epilepsy & 0.020 & 0.882 \\
Seizure type & -0.030 & 0.819 \\
More than one seizure type & -0.156 & 0.229 \\
Seizure frequency & 0.246 & 0.056 \\
Occurrence of soft signs & -0.306 & 0.016 \\
Spikes on EEG & 0.055 & 0.674 \\
Treatment history & -0.044 & 0.737 \\
Current treatment & -0.134 & 0.303 \\
\hline
\end{tabular}


Table 8. Differences between children with and without a risk factor regarding primary and secondary outcome measures

\begin{tabular}{lccccc}
\hline & $\begin{array}{c}\text { N in risk } \\
\text { group }\end{array}$ & $\begin{array}{c}\text { Seizure } \\
\text { frequency }\end{array}$ & $\begin{array}{c}\text { Academic } \\
\text { delay }\end{array}$ & IQ & $\begin{array}{c}\text { Motor } \\
\text { development }\end{array}$ \\
\hline History of febrile seizures & 11 & 0.192 & 0.717 & 0.197 & 0.788 \\
Family history of epilepsy & 17 & 0.412 & 0.465 & 0.051 & 0.439 \\
Early mild developmental delay & 18 & 0.944 & 0.517 & 0.026 & 0.023 \\
Diagnostic delay & 18 & 0.470 & 0189 & 0.658 & 0193 \\
\hline
\end{tabular}

\section{A history of febrile seizures}

Eleven children had febrile seizures before the onset of epilepsy. These febrile seizures had complex features (multiple seizures within $24 \mathrm{~h}$ ) in four children. Compared to the rest of the cohort, children with febrile seizures did not have a different outcome.

\section{Family history of epilepsy}

Seventeen children had a family history of epilepsy. Compared to the rest of the cohort, these children did not have a significantly different outcome.

Early mild developmental delay before onset of epilepsy

Eighteen children were known with mild developmental delay before the onset of their epilepsy. They had speech therapy or physical therapy, or were controlled by a pediatrician because of developmental delay, without further intervention. Compared to the rest of the cohort, children in whom developmental delay had been noted, did not have a worse outcome regarding seizure frequency. The IQ was significantly lower (mean scores 82 versus $90, p=0.026$ ) and motor development was significantly more often abnormal $(p=0.023)$. This indicates that in these children psychomotor development remains delayed. There is no difference in formally assessed academic delay between the groups with and without mild developmental delay before onset of epilepsy. However, more children with developmental delay before onset of epilepsy attended special education $(p=0.036)$.

\section{Diagnostic delay}

Thirty-six children were diagnosed directly after the onset of their epilepsy, in 14 cases it took up to a year to diagnose the disorder as epilepsy. In 13 children it took a longer period (from 29 to 133 months) to diagnose the disorder as epilepsy. In another five children the onset of epilepsy is unknown, but suspected to have been long before the diagnosis. These children are also included in the group 'diagnostic delay'. The outcome did not differ compared to the rest of the cohort. 


\section{Discussion}

We described a very diverse group of children, all diagnosed with CLRE and referred to our outpatient clinic for further analysis of their neurological and neuropsychological state. A broad variety of seizure types was found, ranging from simple partial motor seizures to astatic seizures. On further analysis, our study reconfirmed that prognosis in children with CLRE is not easily predictable. Of all the factors inspected only one factor (having more than one seizure type) showed a statistically significant effect on seizure frequency.

The diversity of our cohort is both a strength and a limitation of our study. The first goal of this study was to describe the neurological and neuropsychological outcome, the second and in essence equally important goal was to find factors correlated to these outcomes. By definition the population with CLRE is a very heterogeneous one, and this is reflected in our cohort. However, this also limits the possibilities of finding similarities between enough cases, in order to find correlations. This complicates the second goal of the study, and indeed only one factor of influence was found.

Even though this study was performed in an epilepsy centre, our cohort is not easy to characterize. Part of our children might be referred to tertiary care because of exhausted treatment options elsewhere. However, a substantial part has been referred to our outpatient clinic because of the easily accessible nature of our programme. The need for referral need not be reflected in the prognostic and risk factors that are analysed. Also, the programme was initially designed to analyse the relationship between epilepsy and academic achievements and behavioural problems in children attending regular education. At the time this study was conducted, the focus of the programme had shifted to a more general screening for all children of school going age. Still, we cannot deny the referral bias that might influence the constitution of our population.

Cohorts including children with cryptogenic epilepsy and more specifically CLRE have been described before in several studies, and can be reviewed to position our cohort. Camfield and Camfield ${ }^{5,14}$ studied a population based cohort of childhood epilepsy patients, and concluded that only half of the children with CLRE will have a truly benign outcome. Arts et al. described course and outcome of seizure control in a hospital based cohort. ${ }^{15,16}$ Roughly half of their CLRE patients have reached and attained seizure freedom (of more than 1 year) after 2 years of follow-up, increasing to two-thirds of patients after 5 years. More recently, Tang-Wai et al. described a cohort consisting of secondarily referred children with cryptogenic epilepsy (38 out of 60 children localization related epilepsy), followed for 4.5 years. ${ }^{17}$ Almost half of their children remained seizure free for over 24 months. As our cohort shows a shorter time since diagnosis than these studies, comparison is difficult. Still, our 1 year terminal remission rate of only $19.1 \%$ is rather grim, and suggests that our population consists of children at risk for a not so benign course of epilepsy.

Almost half of the children in our study sample still experience seizures in a high frequency, even though their epilepsy had been treated for over 2.5 years. Also, 
developmental outcome is not good, as is reflected by a mean $I Q$ at the lower end of the normal range, serious academic delay in more than half of the children and delay of motor development in more than one-third of the children.

Possibly more effect was to be expected from neurophysiological parameters. Unluckily, as a result of the retrospective and clinical nature of our study, this aspect of the clinical status is reduced to a single variable, the presence of interictal activity on EEG.

No negative effect was found for diagnostic delay. As treatment had been started in all children once the epilepsy diagnosis was made, diagnostic delay equals delay of treatment, and ongoing seizures. Apparently the effect of undetected and untreated seizures is limited and does not lead to an increased risk for intractability. This is in line with studies that anti-epileptic treatment does not have an effect on the chronicity of epilepsy but is in fact only anti-convulsant. ${ }^{18}$ it has however been argued before, that suffering from undetected seizures can harm global development and learning potential at school. ${ }^{19}$ Clearly, this did not happen for the 13 children with serious diagnostic delay in our study sample. An explanation might be, that these children have a very benign type of CLRE, possibly their seizures are too subtle or short to have an effect. On the other hand, the factors that are brought about by diagnosing epilepsy, such as treatment and possibly stigma and uncertainty might be an even match to the influence of the seizures. ${ }^{25}$

The existence of early mild developmental delay before the onset of epilepsy does not have an effect on seizure outcome but is correlated with overall neuropsychological outcome. The early delay has not been normalized at the average age of 10 years. This group may be a group that needs special attention with an emphasis on neurodevelopment.

The only significant factor of influence on outcome is the occurrence of more than one seizure type. The finding is concurrent with long-established literature, the prognostic importance of having more than one seizure type has been emphasized after several studies on the outcome of childhood epilepsy. ${ }^{20-23}$ Evidently, this is not only an important but also very easily available factor to verify in daily practice.

The epilepsy in this study sample had been known and treated for durations ranging from zero to 109 months, and the length of this period was not correlated to the seizure frequency. This reflects a non-predictable course of the epilepsy, concurring with previous reports. Camfield and Camfield ${ }^{5}$, e.g. could not identify those children with a risk for poor outcome. The difficult-to-treat characteristic of our cohort is also reflected by the lack of success of the first AED. As many as $75 \%$ of our children had tried more than one AED. Recently other groups also found almost half of the children needed only one AED to reach acceptable outcome. ${ }^{16,17,23}$

As discussed by Sankar, when choosing an AED the correct syndrome diagnosis is of greatest importance leading to successful treatment. ${ }^{24}$ With CLRE this is by definition impossible, there is no true syndrome diagnosis, and there is no class I or II evidence which drug should be tried first.

For the secondary 'developmental' outcomes, there is even less information to support medical decision making in clinical practice. Although a substantial impact on 
neuropsychological outcome was found in this study, none of the prognostic factors were found to correlate to such outcome. It therefore remains unclear whether these findings should be considered an effect of the epilepsy or rather a co-morbidity found in a yet unknown subgroup within the CLRE population.

In conclusion, CLRE remains a complex diagnosis. It holds very little information for decision making in daily care, as well as results in a complex population to investigate in order to increase such knowledge. Even so, this effort must be persisted upon. The many children with this diagnosis, and their caretakers including parents, teachers and clinicians alike, cannot accomplish their jobs without adequate information. Therefore, larger longitudinal studies are needed. 


\section{References}

1. Berg, J. Lin, N. Ebrahimi, F.M. Testa, S.R. Levy and S. Shinnar, Modeling remission and relapse in pediatric epilepsy: application of a Markov process, Epilepsy Res 60 (2004) (1), pp. 31-40.

2. Eriksson and M.J. Koivikko, Prevalence, classification, and severity of epilepsy and epileptic syndromes in children, Epilepsia 38 (1997) (12), pp. 1275-1282.

3. Waaler, B.H. Blom, H. Skeidsvoll and A. Mykletun, Prevalence, classification, and severity of epilepsy in children in western Norway, Epilepsia 41 (2000) (7), pp. 802-810.

5. Camfield and C. Camfield, Epileptic syndromes in childhood: clinical features, outcomes, and treatment, Epilepsia 43 (2002) (Suppl. 3), pp. 27-32.

6. Sillanpää, Learning disability: occurrence and long-term consequences in childhood-onset epilepsy, Epilepsy Behav 5 (2004) (6), pp. 937-944.

7. Reijs, S.G. van Mil, M.H. van Hall, J.B. Arends, J.W. Weber and W.O. Renier et al., Cryptogenic localization-related epilepsy with childhood onset: the problem of definition and prognosis, Epilepsy Behav (2006).

8. Commission on Classification and Terminology of the International League Against Epilepsy, Proposal for revised classification of epilepsies and epileptic syndromes, Epilepsia 30 (1989) (4), pp. 389-399.

9. Kema, M.K.G. Kema-van Leggelo and G.S.O. Handleiding, Manual Groninger school onderzoek, Swets \& Zeitlinger, Lisse (1987).

10. Henderson, The assessment of "clumsy" children: old and new approaches, J Child Psychol Psychiatry $28(1987)(4)$, pp. 511-527.

11. Marson, A. Jacoby, A. Johnson, L. Kim, C. Gamble and D. Chadwick, Immediate versus deferred antiepileptic drug treatment for early epilepsy and single seizures: a randomised controlled trial, Lancet 365 (2005) (9476), pp. 2007-2013.

12. McIntosh and S.F. Berkovic, Treatment of new-onset epilepsy: seizures beget discussion, Lancet 365 (2005) (9476), pp. 1985-1986.

14. Camfield and P. Camfield, Predicting the outcome of childhood epilepsy: a population-based study yielding a simple scoring system, J Pediatr 122 (1993), pp. 861-868.

15. Arts, A.T. Geerts, O.F. Brouwer, A.C. Boudewyn Peters, H. Stroink and C.A. van Donselaar, The early prognosis of epilepsy in childhood: the prediction of a poor outcome. The Dutch study of epilepsy in childhood, Epilepsia 40 (1999) (6), pp. 726-734.

16. Arts, O.F. Brouwer, A.C. Peters, H. Stroink, E.A. Peeters and P.I. Schmitz et al., Course and prognosis of childhood epilepsy: 5-year follow-up of the Dutch study of epilepsy in childhood, Brain 127 (2004) (Pt 8), pp. 1774-1784.

17. Tang-Wai, M. Oskoui, R. Webster and M. Shevell, Outcomes in pediatric epilepsy: seeing through the fog, Pediatr Neurol 33 (2005) (4), pp. 244-250. Article | [18] S. Shinnar and A.T. Berg, Does antiepileptic drug therapy prevent the development of "chronic" epilepsy?, Epilepsia 37 (1996) (8), pp. $701-708$.

18. Shinnar S, Berg AT. Does antiepileptic drug therapy prevent the development of "chronic" epilepsy? Epilepsia 1996; 37(8):701-8.

19. Aldenkamp and J. Arends, The relative influence of epileptic EEG discharges, short nonconvulsive seizures, and type of epilepsy on cognitive function, Epilepsia 45 (2004) (1), pp. 54-63.

20. Brorson and L. Wranne, Long-term prognosis in childhood epilepsy: survival and seizure prognosis, Epilepsia 28 (1987) (4), pp. 324-330.

21. Beghi and $G$. Tognoni, Prognosis of epilepsy in newly referred patients: a multicenter prospective study. Collaborative Group for the Study of Epilepsy, Epilepsia 29 (1988) (3), pp. 236-243. 
22. Kwong, W.Y. Sung, S.N. Wong and K.T. So, Early predictors of medical intractability in childhood epilepsy, Pediatr Neurol 29 (2003) (1), pp. 46-52.

23. Oskoui, R.I. Webster, X. Zhang and M.I. Shevell, Factors predictive of outcome in childhood epilepsy, J Child Neurol 20 (2005) (11), pp. 898-904.

24. Sankar, Initial treatment of epilepsy with antiepileptic drugs: pediatric issues, Neurology 63 (2004) (10 Suppl. 4), pp. S30-\$39.

25. On behalf of the Dutch Study of Epilepsy in Childhood (DUSECH), Three to four years after diagnosis: cognition and behaviour in children with 'epilepsy only'. A prospective controlled study, Brain 128 (2005), pp. 1546-1555. 


\section{Chapter Four}

\section{A follow up study of cryptogenic localization related epilepsy with childhood onset:}

Neurological and neuropsychological course in a tertiary outpatient clinic 


\begin{abstract}
Purpose The course of the neurological and neuropsychological development of children with cryptogenic localization related epilepsy (CLRE) is unclear. We followed a cohort of children in a tertiary outpatient clinic to determine these prognoses.

Method A standard assessment battery yielding neurological and neuropsychological variables was administered to twenty-four children, at two points in time, two years and two months apart. Seizure control is presented as the primary outcome measure, the neuropsychological state of the children is presented by the $1 Q$. Correlations are explored between development and epilepsy variables, including changes over time.
\end{abstract}

Results Seizure frequency improved significantly from $t_{1}$ to $t_{2}$. None of the variables related to the epilepsy or the treatment was correlated with this improvement. $1 Q$ showed non-significant increase, but the delay of educational achievements nevertheless remained serious. These developments did not correlate with the change in seizure frequency, nor with any of the other variables.

Conclusion Seizure frequency improves, which is related to the treatment period. Seizure frequency was already under control at $t_{1}$ in children who had been diagnosed with CLRE for more than three years. At $t_{2}$ the mean duration of the epilepsy had exceeded three years. Therefore it can be concluded that children with cryptogenic localization-related epilepsy belong to the group that can achieve seizure remission or at least fair seizure control, but only after several types of medication have been used. This requires on average a period of three years. With regards to neuropsychological outcome, particularly educational delay takes much time to restore, which should be taken into account when considering treatment withdrawal. 


\section{Introduction}

Up to one third of the children with epilepsy are diagnosed with cryptogenic localization related epilepsy (CLRE). In the 2001 proposal for classification of the epilepsies this type of epilepsy is called focal epilepsy which is probably symptomatic but without a determined aetiology) ${ }^{1}$. Nonetheless, there is a lack of studies describing the short- and long-term prognosis for this group. Most often, the children are described as part of larger epilepsy cohorts and an exact definition of CLRE is difficult to apply. ${ }^{2}$ Since CLRE has no detectable cause, the course and the outcome cannot be predicted from an underlying aetiology. Usually the prognosis is assumed to be somewhere between the benign course of idiopathic epilepsies, and the more malignant course of symptomatic epilepsies. Camfield and Camfield ${ }^{3,4}$ conclude from two studies on predicting outcome, that less than half of the children with CLRE have socalled 'smooth sailing epilepsy', a benign course with easily attained and lasting seizure control. Berg et al. suggest the existence of a wave-like pattern regarding seizure control, with recurring remissions and relapses. ${ }^{5}$ Nevertheless it is not possible to predict which children will have a rather benign outcome, and which children will appear difficult to treat and face comorbidities such as learning disorders and behavioural disturbances.

The aim of this study is to describe the neurological and neuropsychological outcome in a cohort of children diagnosed as suffering from CLRE and followed for up to four years. Furthermore, correlations are explored between epilepsy related variables and both the neurological and neuropsychological outcome measures.

\section{Patients and methods}

\section{Design}

A clinical and non-randomized prospective follow up design was used. Children were assessed at baseline (first admission to our centre; $t_{1}$ ) and at follow-up 12 to 48 months later (second admission; $\mathrm{t}_{2}$ )

\section{Subject selection}

A total of 27 children were consecutively included for a follow up assessment. The children were selected using the following criteria:

- Inclusion criteria: Age at follow up 6 to 16 years, neuroimaging (CT, MRI) without abnormality, a diagnosis of CLRE made or confirmed by a (child) neurologist at our epilepsy centre, using the ILEA classification6 i.e. non-idiopathic localization related epilepsy presumed to be symptomatic, but without a known aetiology.

- Exclusion criteria: $1 Q<70$, absence of neuroimaging, signs or symptoms of brain pathology other than epileptic seizures, other neurological disease, or any known psychiatric disorder. 
The first admission of a total of 68 children has been described elsewhere. ${ }^{7}$ Children were referred to our programme with questions regarding their epilepsy, academic achievements and/or behavioural problems.

Of the 27 children, included for follow-up, three declined the invitation. Motivations for declining were family related problems in one child, an overload of medical interventions in another and one adolescent deciding not to participate without further explanation.

Assessment procedures

A standardized protocol of assessments was followed during a two day admission to our epilepsy centre.

\section{History taking}

Standardized extensive history taking of patients and their parents.

The following variables were recorded:

- age

- sex

- age at onset

- age at diagnosis

- diagnostic delay (the period between seizure onset and epilepsy diagnosis)

- duration of the epilepsy (time since seizure onset)

- duration of treatment (time since epilepsy diagnosis)

- seizure types

- number of seizure types

- current seizure frequency for each seizure type

- a history of status epilepticus

- a history of febrile seizures

- signs of mild early psychomotor delay (i.e. previous follow up of the child because of doubts regarding child development without needing an intervention, or use of physical therapy or language therapy)

- family history of epilepsy

- anti-epileptic drugs and dosage

- treatment history (current AED, treatment duration and number of anti-epileptic drugs tried before deciding to the current regimen)

Seizure types were classified using the ILAE classification. ${ }^{8}$ Subsequently, the seizure types were categorized as follows: a) simple partial seizures; $b$ ) complex partial seizures, which includes seizures with a simple partial onset; c) secondary generalized seizures, which includes both seizures with a partial onset, as well as seizures that appear immediately generalized, such as tonic and astatic seizures.

Whenever a child had more than one seizure type, the primary seizure type was determined by the neurologists. This was based on the severity of the seizures, due to either a high frequency or a severe semiology.

Seizure frequency is recorded in three categories: a) seizure free, for at least one year; b) low seizure frequency, ranging from one seizure in the previous year up to 
one seizure per month; c) high seizure frequency, ranging from more than one seizure per month to daily seizures.

Delay of diagnosis is considered serious whenever it exceeds 12 months.

Neurological physical examination

The following variable was recorded:

- presence of neurological signs or symptoms

Focal neurological disorder would be considered a reason for exclusion. Soft signs, more specifically immaturity of movements, hyper-or hypoactive tendon reflexes, and difficulty with left-right discrimination, were accepted with regards to the diagnosis of CLRE.

\section{Neuropsychological examination}

The following variables were recorded:

- full scale IQ (Wechsler Intelligence Scale for Children-Revised for the Netherlands, WISC-RN ${ }^{9}$

Information was obtained on type of education attained by the child:

- educational delay was assessed by a school achievement test comparable to the Wide-Range Achievement Test (WRAT) in English-speaking countries ${ }^{10}$

Three variables of delay (regarding "words", "sentences" and "arithmetic") were calculated into one variable of general academic delay, and rated as no delay, mild or serious delay, as follows. When a child is delayed no more than five months in any domain, this is regarded a mild delay. When a child is delayed more than five months in two domains, or more than ten months in at least one domain, this is regarded serious delay. Ten months delay equals one school year.

EEG-recording

A 24-hour ambulatory EEG (32 channels) was performed, yielding the following variables:

- presence and percentage of time with epileptic activity: a) no epileptic activity; b) less than one percent of the time; c) more than one percent of the time;

- localization of the epileptic activity: a) focal or multifocal; b) temporal or extratemporal; c) left, right or both hemispheres.

\section{Statistical analysis}

To describe the development of this cohort, several outcome measures are compared regarding their values at $t_{1}$ and $t_{2}$ : seizure frequency, interictal epileptic activity on EEG (IEA), AED treatment, seizure type and IQ. The differences between $t_{1}$ and $t_{2}$ are analysed using paired t-tests, substituted by non-parametric equivalents whenever more appropriate.

Furthermore, correlations are analysed between the primary outcome measures (seizure frequency and the development thereof from $t_{1}$ to $t_{2}$ ) and several prognostic factors: age at onset, duration of the epilepsy, duration of the treatment, the occur- 
rence of soft signs during neurological examination, seizure type, IEA, a history of febrile seizures, a family history of epilepsy, early mild developmental delay and diagnostic delay. The same is carried out for the secondary outcome measures $1 Q$ and academic delay. These correlations are analysed using $\mathrm{Chi}^{2}$, substituted by nonparametric tests whenever necessary because of low counts.

\section{Results}

The clinical and demographic characteristics of this study group are summarized in Table 1.

Table 1. Clinical and demographic characteristics of the study group

\begin{tabular}{ll}
\hline$N$ & 24 \\
\hline Boys:girls & $11: 13$ \\
Age (months) at $t_{2}$ & 140.2 months (110-182; SD 20.27) \\
Time between $t_{1}$ and $t_{2}$ (months) & 27.9 months (16-46; SD 9.07) \\
History of early mild developmental delay & 3 \\
Febrile seizures in history & 3 \\
Status epilepticus & 2 \\
Family history of epilepsy & 4 \\
Serious diagnostic delay & 4 \\
Age at onset & 80.8 months (27-144; SD 27.37) \\
Duration of epilepsy at $t_{2}$ & 58.5 months (26-132; SD 25.94) \\
\hline
\end{tabular}

Febrile seizures, developmental delay, diagnostic delay and family history not occurring in the same 3 or 4 cases. 
The main outcome variables and their values at $t_{1}$ and $t_{2}$ are summarized in Table 2.

Table 2. Main outcome variables and their values at $t_{1}$ and $t_{2}$

\begin{tabular}{|c|c|c|}
\hline & $t_{\mathfrak{f}}$ & $t_{2}$ \\
\hline \multicolumn{3}{|l|}{ Seizure type } \\
\hline Simple partial seizures & 3 & 3 \\
\hline Complex partial seizures & 18 & 19 \\
\hline Secondary generalized seizures & 3 & 2 \\
\hline More than one seizure type & 7 & 7 \\
\hline \multicolumn{3}{|l|}{ Seizure frequency } \\
\hline Seizure free & 6 & 16 \\
\hline Low seizure frequency & 8 & 6 \\
\hline High seizure frequency & 10 & 2 \\
\hline \multicolumn{3}{|l|}{ Interictal epileptiform activity (IEA) } \\
\hline No IEA or less than $1 \%$ of the time & 19 & 19 \\
\hline IEA $>1 \%$ of the time & 5 & 5 \\
\hline \multicolumn{3}{|l|}{ AED } \\
\hline No therapy & 1 & 3 \\
\hline Monotherapy & 18 & 15 \\
\hline Polytherapy & 5 & 6 \\
\hline Full-scale 10 & 92 & 95 \\
\hline \multicolumn{3}{|l|}{ Academic achievement } \\
\hline No delay & 3 & 2 \\
\hline Mild delay & 4 & 1 \\
\hline Serious delay & 14 & 18 \\
\hline
\end{tabular}

Twenty-four children were re-examined after a mean 26 months, In thitteen children seizure frequency had decreased, in one child relapse occurred and for ten children the seizure frequency remained stable (Table 3 ). The change in seizure frequencies was significant (Wilcoxon Signed Ranks Test; $Z=-3.106, p=.002$ ).

Table 3. Change in seizure frequency from $t_{1}$ to $t_{2}$

\begin{tabular}{llcccc}
\hline & & \multicolumn{2}{c}{$\mathrm{t}_{2}$} & Total $\mathrm{t}_{1}$ \\
\cline { 2 - 5 } & seizure free & $\begin{array}{c}\text { low seizure } \\
\text { frequency }\end{array}$ & $\begin{array}{c}\text { high seizure } \\
\text { frequency }\end{array}$ & \\
\hline $\mathrm{t}_{1}$ & seizure free & $5(-)$ & $1(+)$ & & 6 \\
& low seizure frequency & $5(-)$ & $3(-)$ & & 8 \\
& high seizure frequency & $6(-)$ & $2(-)$ & $2(=)$ & 10 \\
Total $\mathrm{t}_{2}$ & 16 & 6 & 2 & 24 \\
\hline
\end{tabular}


Seizure type changed in one child, who had secondarily generalized seizures at $t_{1}$, and complex partial seizures at $t_{2}$. The difference between these types of seizures is for instance the occurrence of an aura, or of obvious motor signs.

In three children, no change of treatment was made between $t_{1}$ and $t_{2}$. In five children (part of the) treatment was withdrawn. In fifteen children either an AED was added, dosage increased or the type of AED changed (Table 4).

For a majority of children more than one AED had been tried in an attempt to reach seizure control, in ten children more than three AEDs had been tried (Table 5). Only six children were treated using polytherapy, and in three AED treatment had been withdrawn (Table 2).

Table 4. Changes of AED treatment

\begin{tabular}{llcccc}
\hline & & \multicolumn{2}{c}{$t_{2}$} & Total $t_{1}$ \\
\cline { 3 - 5 } & & no AED & Monotherapy & Polytherapy & \\
\hline$t_{1}$ & no AED & 0 & 0 & 1 & 1 \\
& Monotherapy & 3 & 14 & 1 & 18 \\
& Polytherapy & 0 & 1 & 4 & 5 \\
Total $t_{2}$ & & 3 & 15 & 6 & 24 \\
\hline
\end{tabular}

Table 5. Number of AEDs tried at $t_{2}$

\begin{tabular}{lc}
\hline Number of AEDs tried at $t_{2}$ & Children $(\mathrm{n})$ \\
\hline no AED & 0 \\
One AED & 3 \\
Two AEDs & 11 \\
Three AEDs & 5 \\
Four or more AEDs & 5 \\
\hline
\end{tabular}

Of the five children who showed IEA on EEG more than $1 \%$ of the time at $t_{1}$, two were IEA-free at $t_{2}$, and one still showed IEA but for less than $1 \%$ of the time. At $t_{1}$ nineteen children showed no IEA or less than $1 \%$ of the time. Sixteen of them were still without IEA on EEG at $t_{2}$, but in the other three IEA had increased (Table 6). The change in IEA was not significant.

Table 6. Changes in IEA

\begin{tabular}{|c|c|c|c|c|c|}
\hline & & \multicolumn{3}{|l|}{ IEA t $t_{2}$} & \multirow[t]{2}{*}{ Tota } \\
\hline & & $\begin{array}{l}\text { no epileptiform } \\
\text { activity }\end{array}$ & $<1 \%$ of time & $>1 \%$ of time & \\
\hline \multirow[t]{3}{*}{$\overline{\mathrm{IEA} \mathrm{t}}$} & no epileptiform activity & 7 & 2 & 0 & 9 \\
\hline & $<1 \%$ of time & 7 & 0 & 3 & 10 \\
\hline & $>1 \%$ of time & 2 & 1 & 2 & 5 \\
\hline Total & & 16 & 3 & 5 & 24 \\
\hline
\end{tabular}


At $t_{1}$ the mean IQ was 92 , at $t_{2} 95$ (Table 2). The change in $I Q$ ranged from losing 7 points to gaining 15 , with a decrease of $I Q$ in nine children, an increase in 15 . This change shows a trend towards significance $(Z=-1.802, p=.072)$.

At $t_{1}$ fourteen children had a serious delay of academic achievements. Four children had a mild delay, and three children were without delay. At $t_{2}$ eighteen children had a serious delay, one had a mild delay and two were without delay of academic achievements. At both moments for three (different) children data were not available, as at $t_{1}$ three children were too young for this test, and at $t_{2}$ three children were too old. Of the 18 children for whom data were available at both moments, one child without delay as well as two children with mild delay at $t_{1}$ showed serious delay at $t_{2}$. Thus, there is no change in school delay.

Correlations with primary and secondary outcomes at $t_{1}$ and $t_{2}$.

The next step in analyzing our study sample, is to investigate the correlations between the outcome measures at both moments of assessment ( $t_{1}$ and $\left.t_{2}\right)$ and the variables of possible influence. The results of these analyses are summarized in table 6.

The only variable correlated to seizure frequency, was duration of treatment $(p<.001)$. At $t_{1}$ children who were seizure free $(n=6$, mean duration 39 months) had been treated significantly longer than children who had either a low seizure frequency ( $n=8,10.88$ months) or a high seizure frequency ( $n=10,17.60$ months).

At $t_{2}$ this difference did not exist anymore.

Correlations with change of seizure frequency from $t_{1}$ to $t_{2}$.

Subsequently, the clinical changes between $t_{1}$ and $t_{2}$ are further analyzed.

The children who experienced an improvement of seizure control from $t_{1}$ to $t_{2}$ differed significantly from the children who did not experience any change of seizure frequency regarding the time that had elapsed between the two measuring points. For children whose seizure frequency did not change, 9.9 more months had elapsed between the two admissions $\left(t_{1}\right.$ and $\left.t_{2}\right)(p=.014)$. Moreover, these children had a significantly longer treatment duration than the children whose seizure frequency improved (18.9 months, $p=.004)$.

There is a highly significant correlation between change of seizure frequency and seizure frequency at $\mathrm{t} 1 \quad\left(r_{s}=-.612, p=.001\right)$. Children with a high or low seizure frequency are more likely to show improvements of seizure control, whereas seizure free children are more likely to stay seizure free or to show increases in seizure frequency.

None of the other variables were correlated with change of seizure frequency. Neither was change of treatment or change of IEA. 


\section{Discussion}

In this study the seizure-outcome improved significantly between the two measuring points for the children as a group. At follow up two thirds of the children were seizure free, which suggests a good prognosis for seizure control in CLRE over a middle long period of two to four years.

Moreover, children who were already seizure free, tended to remain seizure free, and in children with seizures the frequency decreased.

Seizure frequency was found to correlate with the duration of treatment at the first measuring point; the children who were seizure free at baseline had been treated for a much longer period of time than the children who still had seizures. At the second measuring point, the mean treatment duration of the total cohort had exceeded the mean treatment duration of the seizure free group at the first measuring point, and the correlation did not exist any more. This suggests a minimum period necessary to control seizures in CLRE of about three years.

The seizure frequency as observed at the second measuring point resembles the distribution observed in other epilepsy cohorts. $3,4,11,12$ This evolution of seizure frequency can be explained by the observation in our study that a certain period of time is needed to control the seizures in most children with CLRE, and in most studies follow up is long enough to reach seizure control. Eventhough in most children this outcome can be attained using monotherapy, in a vast majority of cases more than one AED is tried before this outcome is reached.

Previously a pattern of seizure control and relapse was described specifically for CLRE. ${ }^{5}$ In the current study, we did not find support for this so called wave-like pattern. As the children have only been investigated twice, there is by definition not enough follow up to detect a wave-like pattern. However, only one out of six seizure free children at first admission had relapsed. Furthermore, children whose seizure frequency did not change, had received treatment for a longer period of time, and also more time between the two measuring points had elapsed. This suggests a stable phase for these children, which concurs with the correlation found between seizure frequency at first measuring point and change of seizure frequency.

Our study did not include any predetermined intervention. Of course, in certain cases the analysis in the clinical program lead to decisions by the treating physician after receiving the conclusion of an expert team. The treatment was altered in twenty children, in fifteen either an increase of dosage, an addition of another drug or a change of AED was applied. Still, no correlation was found between change of treatment and change of seizure frequency.

The IQ score did not change since the first admission. Of all neuropsychological variables representing the cognitive abilities of a child, $I Q$ is the most widely used. It gives an indication of the current cognitive capabilities of a child. It is tempting to assume the $1 Q$ scores of these children had decreased when seizures were frequently disturbing their cognitive abilities. The seizures are then viewed as causes for 
learning impairments, causes that are potentially reversible and treatable: state dependent learning impairments. However, state dependent learning impairments may become permanent when they last for a long time. ${ }^{13-15,21}$ Therefore, treatment considerations are now extended beyond seizure control, to cognitive and developmental aspects of the child in question.

As our study is a clinical study in which children were included when their epilepsy was already present, and in only one child relapse occurred during the study, we cannot confirm a presumed improvement after previous loss of intellectual abilities during periods with seizures. Also, it is likely that type of seizure and duration of ictal events, as well as the occurrence of epileptiform activity on the EEG, are of influence on the effect on cognition. ${ }^{16}$

Even though no correlation could be shown between seizure frequency or change thereof and the IQ score in this cohort, the concurrent improvement supports further study of a possible relationship.

The IQ score reacts quickly to a changing state of the child. On the contrary, the delay in school takes more time to restore. The absence of significant change in academic delay is therefore explained by the relatively short follow up period of the current study. This also leads to considerations regarding AED withdrawal: when a child has been seizure free for two years, academic delay is not likely to be fully recovered. Withdrawal of treatment always poses a threat to the achieved seizure freedom, and through this to recovery of school delay. Relapse occurs in up to a third of patients after AED withdrawal. ${ }^{17-20}$ Moreover, regaining seizure control with the aid of renewed AED treatment is not a guarantee. ${ }^{19}$ Consequently, the child's chances for realizing his/her optimal educational potential are threatened. Still, AED withdrawal and its risks should be considered because of the opposing side effects of AED treatment on the child and their cognition and behavior. Hence, the clinical situation and the decisions which are to be made, remain an issue for the individual patient, parents and clinicians to solve in good understanding of the priorities that provide the best chances on a good quality of life.

In conclusion our study shows that acceptable seizure control can be achieved for children with CLRE in a period of about three years after diagnosis. However, it is clear that more thorough studies are needed to investigate the more specific relations between seizure control and cognitive development in children with CLRE, as well as the course of the epilepsy and the affecting variables. 


\section{References}

1. Engel, J., Jr., (2001) A proposed diagnostic scheme for people with epileptic seizures and with epilepsy: report of the ILAE Task Force on Classification and Terminology. Epilepsia. 42(6): p. 796-803.

2. Reijs RP, van Mil SG, van Hall MH, Arends JB, Weber JW, Renier WO, Aldenkamp AP (2006). Cryptogenic localization-related epilepsy with childhood onset: The problem of definition and prognosis. Epilepsy Behav. Jun;8(4):693-702.

3. Camfield C, Camfield P (1993). Predicting the outcome of childhood epilepsy: A population-based study yielding a simple scoring system. J Pediatr 122:861-868.

4. Camfield P, Camfield C (2002). Epileptic syndromes in childhood: clinical features, outcomes, and treatment. Epilepsia 43 Suppl 3:27-32

5. Berg AT, Lin J, Ebrahimi N, Testa FM, Levy SR, Shinnar S (2004). Modeling remission and relapse in pediatric epilepsy: application of a Markov process. Epilepsy Res 60(1):31-40.

6. Commision on Classification (1989). Proposal for revised classification of epilepsies and epileptic syndromes. Commission on Classification and Terminology of the International League Against Epilepsy. Epilepsia, 1989. 30(4): p. 389-99.

7. Reijs RP, van Mil SGM, van Hall MHA, Arends JBAM, Weber JW, Renier WO, Aldenkamp AP (2007) Cryptogenic localization related epilepsy in children from a tertiary outpatient clinic; is neurological and neuropsychological outcome predictable? Clinical Neurology and Neurosurgery 109(5):422-30.

8. Commision on Classification (1981). Proposal for revised clinical and electroencephalographic classification of epileptic seizures. From the Commission on Classification and Terminology of the International League Against Epilepsy. Epilepsia 22(4): p. 489-501.

9. Vander Steene G, Van Haasen PP, De Bruyn EEJ, Coetsier P, Pijl YJ, Poortinga YH, Spelberg HC, Stinissen J. (1986) WISC-RN: Wechsler Inteiligence Scale for Children-Revised. Lisse, The Netherlands: Swets \& Zeitlinger.

10. Kema GM, Kema-van Leggelo MKG (1987). Handleiding G.S.O. [Manual Groninger school onderzoek]. Llsse: Swets\&Zeitlinger.

11. Berg AT, Shinnar S, Levy SR, Testa FM, Smith-Rapaport S, Beckerman B, Ebrahimi N (2001). Two-year remission and subsequent relapse in children with newly diagnosed epilepsy. Epilepsia;42(12):1553-62.

12. Shinnar S, O'Dell C, Berg AT. Distribution of epilepsy syndromes in a cohort of children prospectively monitored from the time of their first unprovoked seizure. Epilepsia 1999;40(10):1378-83.

13. Beghi M, Cornaggia CM, Frigeni B, Beghi E (2006). Learning disorders in epilepsy. Epilepsia 47 Suppl 2:14-8.

14. Besag FM (2006). Cognitive and behavioral outcomes of epileptic syndromes: implications for education and clinical practice. Epilepsia 47 Suppl 2:119-25.

15. Aldenkamp AP, Arends $J$ (2004a). Effects of epileptiform EEG discharges on cognitive function: is the concept of "transient cognitive impairment" still valid? Epilepsy Behav 5 Suppl 1:S25-34

16. Aldenkamp $A$, Arends $J(2004 b)$. The relative influence of epileptic EEG discharges, short nonconvulsive seizures, and type of epilepsy on cognitive function. Epilepsia 45(1):54-63.

17. Verrotti A, Morresi S, Basciani F, Cutarella R, Morgese G, Chiarelli F (2000a). Discontinuation of anticonvulsant therapy in children with partial epilepsy. Neurology 55(9):1393-5.

18. Verrotti A, Morresi $S$, Cutarella R, Morgese G, Chiarelli F (2000b). Predictive value of EEG monitoring during drug withdrawal in children with cryptogenic partial epilepsy. Neurophysiol Clin 30(4):240-5. 
19. Sillanpää $M$, Schmidt $D(2006)$. Prognosis of seizure recurrence after stopping antiepileptic drugs in seizure-free patients: A long-term population-based study of childhood-onset epilepsy. Epilepsy \& Behavior 8(4):713-719.

20. Murakami M, Konishi T, Naganuma $Y$, Hongou K, Yamatani $M$ (1995). Withdrawal of antiepileptic drug treatment in childhood epilepsy: factors related to age. J Neurol Neurosurg Psychiatry 59(5):477-81.

21. Cornaggia CM, Gobbi G (2001). Learning disability in epilepsy: definitions and classification. Epilepsia 42 Suppl 1:2-5; discussion 19-20. 


\title{
Chapter Five
}

\author{
Motor function in children with \\ cryptogenic localization related \\ epilepsy
}




\section{Abstract}

Introduction: In CLRE specific learning difficulties and motor problems may occur. The aim of this study is to study whether CLRE or the accompanying specific learning difficulties influence the occurring problems in motor function.

Methods: The results of a clinical programme which included 140 children with CLRE and without epilepsy, as well as with and without specific learning difficulties are analysed using Chi-square.

Results: In the CLRE group 35\% score below the $5^{\text {th }}$ percentile (poor motor function). No correlations with epilepsy variables or the occurrence of specific learning difficulties is found.

Discussion: Children with CLRE are at risk for poor motor function. Therefore, their development is best monitored using a multi-dimensional approach, including cognitive development and motor functioning. 


\section{Introduction}

Problems with both cognitive and motor development have been reported in children with epilepsy, even in children without obvious neuroimpairment. ${ }^{1,3,6}$ Many explanations can be proposed for these problems. They may reflect the brain damage that is also held accountable for the epilepsy. They may be a side-effect of the anti-epileptic drugs (AEDs). ${ }^{1,5}$ They can be also a direct effect of the epileptic seizures, and therefore be related to the severity of the seizures, or to factors such as seizure frequency, seizure type or duration of the epilepsy. ${ }^{1}$ Also the localization of the epileptic focus might be important. None of these explanations have been confirmed indisputably. Motor development and cognitive development are presumed to be interrelated. Many children with problems in cognitive functioning have problems with their motor functioning as well. A combined development through which both functions can be affected by a common factor is supposed. However, it is not clear by which mechanism. $^{10}$

Cognitive disfunctioning can consist of mental retardation (an IQ below 70) or , when there is no mental retardation, can appear in the form of specific learning difficulties.

Up to one third of children with epilepsy is diagnosed with cryptogenic localization related epilepsy (CLRE). In CLRE no specific cause is known for the epilepsy. In CLRE there is no mental retardation (MR) and there are no neurological disorders, except for the epilepsy. However, specific learning difficulties and motor problems may occur, as they do in children with other types of childhood epilepsy. As there is little literature describing the course of CLRE in childhood ${ }^{6}$, much less is known about the motor development and possible disruption.

In this study we describe the motor function in 67 children with CLRE and try to answer the question whether the epilepsy influences motor function, or possibly the accompanying specific learning difficulties.

\section{Methods}

Design

CLRE patients are compared to controls with regard to their motor function, the occurrence of learning disorders and the correlations between these characteristics. For the study, a systematic cross-sectional open clinical and non randomized design is used.

\section{Subject selection}

Patients who were referred to our epilepsy centre for a child neurological programme were consecutively included. This programme exists of a clinical and neurophysiological assessments, a neuropsychological test battery, and motor function screening. 
A child was considered a study subject whenever a diagnosis of CLRE was made or confirmed by a (child) neurologist at our epilepsy centre using the ILAE classification $^{4}$, i.e. localization related epilepsy presumed to be symptomatic, but without a known aetiology.

- Inclusion criteria for this study: Age at admission 6-16 years, neuroimaging (CT, MRI) without abnormality.

- Exclusion criteria: $I Q<70$, neuroimaging abnormalities, signs or symptoms of brain pathology other than epileptic seizures, any other neurological disease.

Children, who were referred to our centre, with a suspicion of an epileptic disorder but did not have epilepsy, were considered as a non-epilepsy control group. Therefore they form a surrogate control group with learning disabilities.

Assessment of cognitive functions and learning disabilities:

The full scale IQ (Wechsler Intelligence Scale for Children-Revised for The Netherlands, WISC-RN) was used. The presence of a specific learning difficulty was reflected in the neuropsychological test results.

A specific learning difficulty was diagnosed when a child had specific difficulties in learning behavior, resulting in problems with certain skills learned at school.

\section{Screening of motor function}

For the assessment of motor functioning, the Movement Assessment Battery for Children (mABC) was used. ${ }^{9}$ This test battery is a screening instrument for motor impairment, specifically aimed at school performance and social adjustment in children. Using standardised norm values, the achievements of a child can be compared to those of peers. The test yields a total score, a percentile score and also percentile scores per age-striatum regarding three subdomains: manual dexterity, ball skills, static and dynamic balance.

Motor fuctioning is regarded disturbed when a child scores on or below the fifth percentile.

Percentile score on the total $\mathrm{mABC}$ battery as well as percentile scores representing the three subdomains were used as outcome measures for motor functioning.

\section{Statistical analysis}

Groups with and without epilepsy, and with and without learning disabilities were compared using $\mathrm{Chi}^{2}$, two-sided, alpha set at 0.05 . 


\section{Results}

In total, 140 children were included, 67 with CLRE and 73 without epilepsy. Regarding distribution of sexes, age and $I Q$, the two groups did not differ significantly (see also Table 1).

Results are presented in Table 2.

Table 1. Characteristics of the cohort

\begin{tabular}{lll}
\hline & children with CLRE $(n=67)$ & Children without epilepsy $(n=73)$ \\
\hline girls:boys & $35: 32$ & $31: 42$ \\
age (mean) & 9 years (107.8 months, SD 24.8) & 9.1 years (109.2 months; SD 25.5) \\
IQ & $91.2(70-120 ; 10.5)$ & $91.8(70-131 ;$ SD 13.4) \\
\hline
\end{tabular}

Table 2. Motor functioning as related to CLRE

\begin{tabular}{lccc}
\hline Motor functioning & CLRE $(n=67)$ & controls $(n=73)$ & $p$ \\
\hline total score mABC $\leq 5$ th percentile & $24(35.8 \%)$ & $16(21.9 \%)$ & 0.092 \\
Manual dexterity score $\leq 5$ th percentile & $17(25.4 \%)$ & $13(17.8 \%)$ & 0.308 \\
Ball skills $\leq 5^{\text {th }}$ percentile & $20(29.9 \%)$ & $21(28.8 \%)$ & 1.000 \\
Balance $\leq 5$ th percentile & $13(194 \%)$ & $13(17.8 \%)$ & 0.831 \\
\hline
\end{tabular}

Motor function of the children with CLRE was below the fifth percentile in 35 percent of the group. One fifth of the control group showed disturbed motor functioning. This difference is not statistically significant $(p=0.092)$.

The percentile scores reflecting the subdomains manual dexterity, ball skills and balance did not show any significant difference between controls and CLRE patients. The subscores that form these percentile scores of the subdomains did not differ significantly between controls and CLRE patients.

In this cohort, 114 out of 140 children have a learning problem or have specific learning difficulties, 50 out of 67 children with CLRE (78.1\%), and 64 out of 73 control children $(87.7 \%)$. This difference in presence of specific learning difficulties between the groups with and without epilepsy is not significant $(p=0.053)$. The two groups do not differ regarding IQ score either. The results for this subdivision of the cohort are presented in Table 3. No significant differences were found between the two groups with and without specific learning difficulties regardless of epilepsy diagnosis.

Table 3. Motor functioning as related to learning disabilities

\begin{tabular}{lccc}
\hline Motor functioning & $\begin{array}{c}\text { no learning disability } \\
(\mathrm{n}=27)\end{array}$ & $\begin{array}{c}\text { learning disability } \\
(\mathrm{n}=125)\end{array}$ & $p$ \\
\hline total score mABC $\leq 5$ th percentile & $8(30.8 \%)$ & $32(28.1 \%)$ & 0.812 \\
Manual dexterity score $\leq 5$ th percentile & $5(19.2 \%)$ & $25(21.9 \%)$ & 1.000 \\
Ball skills $\leq 5^{\text {th }}$ percentile & $7(26.9 \%)$ & $34(29.8 \%)$ & 1.000 \\
Balance $\leq$ 5th percentile & $3(11.5 \%)$ & $23(20.2 \%)$ & 0.408 \\
\hline
\end{tabular}


Furthermore, no correlation was found between a diagnosis of a specific learning difficulty and motor functioning, not within the CLRE group, neither within the control group (Table 4).

Table 4. Motor functioning and specific learning difficulties are not correlated

\begin{tabular}{lcc} 
& Pearson Correlation & $P$ \\
\hline No epilepsy $(n=73)$ & -0.127 & 0.285 \\
CL.RE $(n=67)$ & 0.038 & 0.763 \\
\hline
\end{tabular}

\section{Discussion}

More than one third of our CLRE children are found in the group of the worst motor functioning. This is more than the five percent what is present in a normal agedcontrolled population. However, this was not significantly different from our nonepilepsy control group. The motor disfunction found in our CLRE group is therefore not necessarily related to the epilepsy. Furthermore, the motor disfunction is not related to the specific learning difficulties as diagnosed within our cohort.

The occurrence of poor motor function is seven times more frequent in CLRE compared to the general population. This is a worrisome observation. Previously, we described a group of CLRE children as part of a more general cohort of childhood epilepsy. ${ }^{3}$ We did not find disturbed motor function for this group. Gloersen et al. found over half of their cohort to have motor difficulties when screened using the mABC. ${ }^{11}$ These difficulties were predominantly found in the children with MRIdetectable lesions and children with symptomatic epilepsy. There was no correlation with AED treatment or with seizure frequency. Beckung et al. ${ }^{1}$ also found abnormal motor function, mainly in gross motor function, balance and coordination. The children in this cohort were also without MR or obvious neuroimpairment. They found a correlation with duration of epilepsy, as well as with treatment. Children with monotherapy performed better than both children with polytherapy as well as children without therapy. This suggests an effect of uncontrolled epilepsy on motor functioning of the child. We did not find this in our other study, where we tried to correlate epilepsy variables such as age at onset and seizure frequency, to motor function as an outcome measure.

By definition, children with CLRE have no focal neurological deficits. Neurological soft signs as observed by the neurologist, are accepted when considering CLRE as diagnosis. Poor motor function as an outcome of this test battery should be regarded to be the more subtle dysfunctions regularly labeled as 'soft signs'. Children with CLRE therefore have no gross psychomotor dysfunctions, but do encounter more problems in daily functioning than do children in the general population. 
With $20 \%$ of our control group showing motor difficulties it is clear that this is not an unselected control group. The children were originally referred to our epilepsy centre because of a clinical suspicion of an epileptic disorder. We did not diagnose these children as having epilepsy, and therefore they were appointed control subjects. However, they are also not comparable to the general population. This impaired control group might prevent significant differences to be found. But it is a welcome addition to the values of the norm population, because of the learning difficulties present and measurable in this group.

Generally it is assumed that children with epilepsy are at risk for learning problems, whether it be learning disability or specific learning difficulties. ${ }^{8}$ In both our groups learning difficulties are diagnosed in part of the children. This offers the possibility to analyse the correlation between epilepsy, learning difficulties and motor functioning. In this study, no correlation was found, which concurs with research studying the correlation between motor and cognitive development regardless of epilepsy. ${ }^{10}$

Eventhough no correlation is found between the epilepsy and the outcome of motor function, the increased frequency compared to the general population (i.e. the norm group of the Movement $A B C$ ) does point out the vulnarability of these children. Not much is known regarding the prognosis of children with CLRE. Neither the course of their epilepsy, nor the outcome regarding neurological, psychomotor or educational outcome have been studied elaborately, but it is becoming more clear that the course for these children is not purely benign. ${ }^{2,6-8}$ Regardless of a direct relation with the state of the epilepsy (the level of seizure control), these children are at risk in daily life, as their achievements in school are more likely to lag behind compared to their peers. Moreover, a poor motor function puts them further at risk socially, which further decreases the general wellbeing of the child.

This study underlines that children with CLRE are best monitored using a multidimensional approach, as too little is known on the course of the epilepsy and individual development, while they are at risk for additional psychomotor problems. Not only the control of seizures deserves attention, but also also cognitive development and motor functioning should be surveyed and guided by the relevant experts. 


\section{References}

1. Beckung $E$, Uvebrant P. Hidden dysfunction in childhood epilepsy. Dev Med Child Neurol. 1997 Feb;39(2):72-8

2. Berg AT, Lin J, Ebrahimi $N$, et al. Modeling remission and relapse in pediatric epilepsy: application of a Markov process. Epilepsy Res 2004;60:31-40.

3. Boelen et al. Effect of epilepsy on psychomotor function in children with uncomplicated epilepsy. Dev Med Child Neurol. 2005 Aug;47(8):546-50.

4. Commission on Classification and Terminology of the International League Against Epilepsy Proposal for revised classification of epilepsies and epileptic syndromes. Epilepsia 1989;30:389-399.

5. Maalouf M, Takahashi CD, Reinkensmeyer DJ, Cooper DM, Rho JM. Impaired motor control in patients with benign focal epilepsy of chldhood. J Child Neurol. 2006 Feb; 21(2):157-60.

6. Reijs RP, van Mil SG, van Hall MH, Arends JB, Weber JW, Renier WO, Aldenkamp AP. Cryptogenic localization-related epilepsy with childhood onset: The problem of definition and prognosis. Epilepsy Behav 2006 Jun;8(4):693-702.

7. Reijs RP, van Mil SG, Arends JB, van Hall MH, Weber JW, Renier WO, Aldenkamp AP. Cryptogenic localization related epilepsy in children from a tertiary outpatient clinic: is neurological and neuropsychological outcome predictable? Clin Neurol Neurosurg. 2007 Jun;109(5):422-30.

8. Sillanpää M. Learning disability: occurrence and long-term consequences in childhood-onset epilepsy. Epilepsy Behav. 2004 Dec;5(6):937-44.

9. Smits-Engelsman BCM. (1998) Movement ABC; Nederlandse Handleiding. Swets en Zeitlinger Lisse. (In Dutch).

10. Wassenberg R, Feron FJ, Kessels AG, Hendriksen JG, Kalff AC, Kroes M, Hurks PP, Beeren M, Jolles J, Vles JS. Relation between cognitive and motor performance in 5- to 6-year-old children: results from a large-scale cross-sectional study. Child Dev. 2005 Sep-Oct;76(5):1092-103.

11 Gloersen G, Loyning T, Nakken KO. Hidden motor dysfunctions in children with epilepsy. Tidsskr Nor Laegeforen. 2000 Aug 10;120(18):2115-7. 


\section{Chapter Six}

General discussion 


\section{Introduction}

Cryptogenic localization related epilepsy (CLRE) can be considered a non-diagnosis, a term to be used for lack of a true diagnosis. It describes the occurrence of epileptic seizures with a localized onset (localization related epilepsy), that cannot be related to a lesion or known neurological disorder (cryptogenic), nor can it be recognized as an idiopathic epilepsy syndrome. Diagnosing CLRE in a child implies that other epilepsy diagnoses, as well as causes for the epilepsy, have been ruled out. The diagnosis mainly ascertains the lack of resemblance to other children with epilepsy, because the recognition of significant similarities would lead to the definition of a new epilepsy syndrome.

\section{Heterogeneity and the purpose of a diagnosis}

A diagnosis is useful, when it leads to information about the expected course of a disease, and when it provides guidelines for possible interventions. This information is collected by observing patients, either without treatment (the natural course of a disease) or with well described treatments intervening the course of the disease and influencing outcome. With regard to epilepsy and the outcome for the patient, the cause that is responsible for the epilepsy is the best predictor for the outcome. ${ }^{1,7,12-}$ ${ }^{14,16}$ The cause for CLRE is presumed to be symptomatic. This implies that etiological questions will be answered in time, when neuroimaging techniques and knowledge about epilepsy and its pathological courses develop. Because of this presumption, CLRE is often incorporated in cohorts of symptomatic localization related epilepsy (SLRE), whenever course, prognosis or the effectiveness of interventions is investigated. In Chapter Two we discuss the validity of a separate classification of CLRE amongst childhood epilepsies. As argued, a separate position (in stead of classifying these children as a subgroup of SLRE) may gain more information, usefull for this group of children, especially since it is such a large group within the childhood epilepsy population. A specific statistical procedure was used to compare children with CLRE to IGE and SLRE, with regards to several variables describing the epilepsy. We concluded that the epilepsy in children with CLRE has significantly different characteristics when compared to the other two types and requires a separate classification.

The constitution of any cohort of CLRE patients thus depends on the progress of knowledge and the development of related techniques at that moment in time. In other words: a 2006 cohort will differ from a 2000 cohort as well as from a 2023 cohort. New syndromes and etiologies will be recognized over time, and patients with a former CLRE diagnosis will be labeled differently. The results in children with CLRE are therefore of a more temporary nature than those in other epilepsy diagnostic groups. Yet, techniques and knowledge do not progress that fast, and there are many children for whom -at present- no other diagnosis than CLRE can be given. To be more 
precise: one third of children with epilepsy are diagnosed with CLRE. These children and their parents are confronted with a diagnosis that holds limited information with respect to cause/etiology and prognosis. The neurologist or pediatrician has no definite answers. Treatment policy mostly consists of a 'wait and see what happens to the child'. Which treatment will control the seizures, at what cost when considering side effects? When is it safe to try and withdraw these drugs? Will the child suffer behavioral problems, or educational delay?

\section{Existing knowledge}

When analyzing the existing literature on CLRE with a childhood onset, firstly the disagreement on the interpretation of the current classification stands out. Several characteristics are under discussion whether their occurrence implies a symptomatic rather than a cryptogenic type of epilepsy. Mental retardation is one of these characteristics. Mental retardation in a child increases the chances to develop epilepsy, and also suggests a damaged brain which can be considered the possible cause for the epilepsy. Yet in some studies children with a mental retardation and epilepsy (and no MRI abnormalities) are classified as having SLRE while in other studies as having CLRE. Another characteristic is the appearance of focal epileptiform activity on EEG, which some authors used as a criterion for symptomatic epilepsy. This influenced the composition of the CLRE cohorts in a series of otherwise impressive studies. ${ }^{2-4}$ Today however, there seems consensus that focal epileptiform activity on EEG does not necessarily lead to a symptomatic diagnosis and children are classified as having CLRE. Whether neuroimaging is imperative to ascertain the cryptogenicity of the epilepsy is also left open for discussion, and if so, what technique or level of imaging is should be used. One of the dilemmas posed by new techniques is how to interpret functional abnormalities in the MRI when no structural MRI abnormalities were found. Because of the indigent definition of CLRE, it is of utmost importance to be clear on the characteristics of the cohort under study. For our studies, including the review, we defined our CLRE cohort as follows: children with localization related epilepsy, in whom no syndromic diagnosis or etiological pathology could be related to their epiJepsy, children with mental retardation (either clinically or neuropsychologically determined) were excluded, as well as children in whom no neuroimaging was performed.

This definition of the diagnosis CLRE leaves only a few studies to include when gathering information from current literature. Regarding seizure control we might conclude that a minority of the children will experience a benign course. This is defined as follows: the first anti-epileptic drug (AED) will result in seizure freedom and no seizure relapse will occur. ${ }^{1,6}$ For a larger group more types of medication must be used before seizures are controlled, or seizure freedom will not be achieved at all. Furthermore, the reviewed studies suggested that a wave like pattern of remission and relapse is characteristic for CLRE. ${ }^{5}$ 
Generally, when children have been seizure free for one or two years, withdrawal of medication will be discussed. In up to a quarter of children with CLRE withdrawal of AEDs causes seizure relapse. ${ }^{8,9,17}$ Reintroduction of the AED does not always result in renewed remission.

Whether or not seizures are controlled, children with epilepsy have a higher chance of suffering from behavioral and cognitive disorders compared to children without epilepsy. If occurring, these disorders influence daily life, as well as future achievements of the children, both socio-economically and emotionally. Therefore, these aspects cannot be ignored when describing or predicting outcome.

This is also true for children with CLRE. Moreover, stress for the parents related to the uncertainty regarding prognosis is proposed as a possible cause for behavioral problems in children with CLRE. ${ }^{10}$ Also, children with CLRE had strikingly more delays in school achievement than children with symptomatic or idiopathic epilepsy. ${ }^{11}$

With these known facts, and the lack thereof, we started studying CLRE in our own clinic. The primary goal was to describe the cohort, and relate epilepsy factors to both types of outcome measures: seizure frequency and neurocognitive development.

\section{Methodology}

\section{Designs}

Chapters Three and Four may be regarded the main two studies presented in this thesis. In both studies, we collected variables related to the epilepsy, variables related to the child and variables representing the outcome of the child. We then tried to correlate these variables, to study whether outcome can be predicted from measurable variables at an early stage in the course of the epilepsy.

In Chapter Three a study is described, carried out following a systematic crosssectional open clinical and non-randomized design. The data used in this study were collected from 68 patients included in a standardized clinical program. Subsequently, we analyzed the data in search of correlations between certain epilepsy related characteristics and other patient related characteristics, and the outcome as represented by several epilepsy related and developmental variables.

In Chapter Four a study is presented, in which a clinical and non-randomized prospective follow up design was used. Twenty four children are assessed at baseline and after a follow-up, 12 to 48 months after the first assessment. Again, correlations were studied between epilepsy related variables and the outcome both neurologically and neuropsychologically. 
The children included in both studies were admitted in a clinical programme in which the children were admitted for three days during which a standardized protocol of assessments was carried out. Besides neurological investigation and history taking, these include observation by trained nurses, EEG recordings, neuropsychological testing, psychomotor screening and educational assessment.

Our clinic is a tertiary clinic; patients are referred from hospitals by neurologists, child neurologists and pediatricians. This suggests a more complex group, patients whose epilepsy could not be controlled easily or experience all kinds of side effects or comorbidities or patients with difficult-to-diagnose epilepsies.

However, we consider the included group as representative for the general population with CLRE and not only for the very severe types of CLRE. Firstly, programme is easily accessible for patients from secondary centres and mostly return to the care of their secondary centre physician right after the analyses have finished, which stimulates secondary centres to use the programme at an early stage and for all kinds of patients. Secondly, many children are referred because of the behavioiural comorbidities, rather than the severity of their epilepsy.

\section{Variable selection}

To decide which data to collect and analyse, we reviewed existing literature on the outcome of CLRE. Of course, the choice for some variables is inevitable. First of all, not only in CLRE but in epileptic research in general it is assumed that an earlier age of onset of the seizures will have a negative impact on outcome. As yet it is in debate whether this is an effect of the accumulating effects of seizures, the duration of the epilepsy or the stage of brain development achieved before the seizures start which is related to the issue of brain plasticity. Because of these doubts, duration and seizure frequency in the year before admission are also used as variables. Second, seizure semiology reflects the amount of involvement in the brain, and is an obvious way to subclassify a heterogeneous group such as CLRE. Moreover, having more than one seizure type is known to be an ominous sign in other epilepsy syndromes as well. Third, we chose the number of AEDs that have been tried is used, mainly as a reflection of the intractability of the seizures. Fourth, EEG recording is considered a means of quantifying the epileptic activity in the brain. It has been found to correlate to outcome and outcome of drug withdrawal. Also, a high percentage of interictal epileptiform activity during sleep is known to be correlated to worse cognitive outcome in either certain syndromes or in epilepsy in general. Finally, a low or subnormal $I Q$, clinically known as mental retardation, is regarded a better prognostic variable for epilepsy outcome than neurological deficit. Both are absent by definition in CLRE, however IQ scores also vary within the normal range. This variation could also be correlated with a certain the course of the epilepsy. 


\section{Have we answered our questions?}

Our main goal was to describe our CLRE population and its outcome, and to find factors correlated to this outcome. In particular, variables that are easily accessible in the early period when a diagnosis is made, had our interest.

The cohort from our cross-sectional study was very heterogeneous regarding the clinical aspects of the epilepsy: seizure type, seizure frequency and also the age of onset. Half of the children had a high seizure frequency. Children had been diagnosed up to 106 months before admission to our program, but there were also some children who were newly diagnosed during the admission. There were many different seizure types, even though the majority was complex partial seizures resembling absences.

Of all factors studied only one factor, i.e. having more than one seizure type was found to be significantly related to a high seizure frequency (as a measure of outcome).

Surprisingly, diagnostic delay did not correlate to outcome. Delayed diagnosis reflects delayed treatment, and this had no effect on the outcome of the epilepsy or the achievements in school.

The second follow up study included 24 children. During follow up seizure frequency improved significantly. In only one child seizure frequency increased. All other children who were already seizure free at the first measuring point, were still seizure free at follow up. The improvement of seizure frequency was inversely correlated to the duration of the treatment: children who had been treated for a longer period at the first measuring point had a better prognosis. This suggests that seizure control in CLRE requires longer treatment duration.

A slight increase in $I Q$ was noted when comparing endpoint with baseline. However with such a short follow up, improvement in educational achievements was not to be expected. Still, these findings are encouraging for further research, and allow for the assumption that achieving a stable state regarding the epilepsy is beneficial for the cognitive development of children with CLRE. Further investigation of the neuropsychological data will shed more light on these assumptions.

One of the outcome measures in the cross-sectional study was motor functioning. No correlation with any epilepsy factor was found. The study in Chapter Five reveals there are problems with motor functioning in $35 \%$ of our CLRE children. A surrogate control group consisted of children who had been referred to our epilepsy centre, but were not diagnosed with epilepsy. The outcome of the CLRE group did not differ significantly from this group. Furthermore, comparing these two groups showed no correlation between learning disabilities (occurring equally in both groups) and motor function. So, children with CLRE have a higher risk for both learning disabilities and motor function problems. These are nevertheless not obviously correlated to the epilepsy factors, nor to each other.

In our cross-sectional study, not even one fifth of children are seizure free. Two thirds of our children reexamined after one to four years, at a mean duration of 26 months, 
are seizure free. With one exception, there had only been improvement of seizure control in this cohort. This suggests a growing control of seizures during the course of CLRE. The mean duration of epilepsy at that point in time when reasonable seizure control is achieved is 4.10 years. Previously published results from other authors describe longer periods of follow up, in which an even higher remission rate is found. We therefore may conclude that CLRE is not per se a condition with worse prognosis and will not per definition lead to intractability. Much more patience is needed to achieve seizure control in comparison to more benign types of childhood epilepsy (refs zoeken). The correlation of seizure frequency with duration of treatment, as we found in our prospective study, supports this conclusion.

Berg et al. describe a relatively large risk of relapse for children with CLRE, and confirm this pattern of remission and relapse in another study using a Markov model (a wave-like pattern of seizure remission and relapse). ${ }^{5}$ As a group the remission rate of $80 \%$ will be retained after a substantial duration of epilepsy, but for the individual child it seems to be a frequently renewed search for seizure control. We cannot support this finding, as our prospective study only has two measuring points but our data certainly do not confirm such a wave-like pattern of remission and relapse'.

\section{Relevance for daily practice}

As we concluded in Chapter Four, most children with CLRE will achieve seizure freedom. This may take more time than in other types of epilepsy but the distribution of seizure frequency of children with CLRE after four years are comparable to those of children with for instance rolandic epilepsy after two years. When a child has more than one seizure type, it will be more difficult to achieve seizure freedom.

Furthermore, none of the epilepsy variables, not even seizure frequency appeared to have an impact on the behavioural outcomes (such as eduational achievements or motor functioning). This implies that the need to achieve seizure remission is a relative aim. Especially for children suffering from seizures with a benign semiology at a low frequency one has to consider what is to gain from further increase of therapeutic stress on the child and its development. But as parents and physicians are aware of the side effects of AED, they are already making these choices carefully. Nonetheless, epilepsy has its co-morbidities. For the child and its environment, most impact comes from behavioral disorders and learning difficulties. These are also of great influence on the capabilities of the child in later life, as they interfere with social development and school achievements of the child. It might well be, that this impact of the epilepsy on learning and behavior decreases when seizure control is reached. However, bearing in mind the side effects of AEDs, clinicians as well as parents are inclined to withdraw the treatment when seizure control seems stable. In general this is considered after a seizure free period of two years. In our study it was concluded that improvement of school achievement, moreover the rectification of school delay, takes up more time. Besides the risk on the recurrence of seizures, the impact on psychosocial development should be taken into account when considering AED withdrawal. In daily practice of counseling children with CLRE, the guidance of children 
and their parents with regards the behavioral problems and learning difficulties will prove to be an important tool in influencing the development of the child, and therefore the outcome. ${ }^{15}$

\section{Conclusion}

As yet we lack information about CLRE, its course. Partly this is due to the definition of CLRE, causing the cohort to change over time. As a consequence, there is not sufficient information available to provide the children and their parents with a clear prognosis, and to choose the adequate form of treatment. Our studies did not provide definite and conclusive answers to change this situation completely.

However, based on the work described and reviewed in this thesis some conclusions directed at daily practise can be drawn. For both clinicians, children and their parents it should be clear that the course of CLRE and its impact on the development of the child remain inpredictible. Seizure control can be reached and possibly attained, but it takes time, and several revisions of treatment regime.

Moreover, monitoring the child regarding its psychosocial and motor development, as well as its educational course, appears as important to the eventual outcome as the effort to control seizures. 


\section{References}

1. Arts WF, Brouwer OF, Peters AC, Stroink H. Peeters EA, Schmitz PI, van Donselaar CA, Geerts AT. Course and prognosis of childhood epilepsy: 5 -year follow-up of the Dutch study of epilepsy in childhood. Brain. 2004;127:1774-84.

2. Berg AT, Levy SR, Testa FM, et al. Classification of childhood epilepsy syndromes in newly diagnosed epilepsy: interrater agreement and reasons for disagreement. Epilepsia 1999;40:439-44.

3. Berg AT, Shinnar S, Levy $S R$, et al. How well can epilepsy syndromes be identified at diagnosis? A reassessment 2 years after initial diagnosis. Epilepsia 2000;41:1269-75.

4. Berg AT, Shinnar S, Levy SR, et al. Two-year remission and subsequent relapse in children with newly diagnosed epilepsy. Epilepsia 2001;42:1553-62.

5. Berg AT, Lin J, Ebrahimi N, et al. Modeling remission and relapse in pediatric epilepsy: application of a Markov process. Epilepsy Res 2004;60:31-40.

6. Camfield $C$, Camfield P. Predicting the outcome of childhood epilepsy: a population-based study yielding a simple scoring system. J Pediatr 1993;122:861-8.

7. Hauser WA, Rich SS, Lee JR, Annegers JF, Anderson VE. Risk of recurrent seizures after two unprovoked seizures. N Engl J Med 1998;338:429-34.

8. Murakami $M$, Konishi $T$, Naganuma $Y$, et al. Withdrawal of antiepileptic drug treatment in childhood epilepsy: factors related to age. J Neurol Neurosurg Psychiatry 1995;59:477-81.

9. Ohta $H$, Ohtsuka $Y, T$ suda $T$, et al. Prognosis after withdrawal of antiepileptic drugs in childhood-onset cryptogenic localization-related epilepsies. Brain Dev 2004;26:19-25.

10. Oostrom KJ, Schouten A, Kruitwagen $\mathrm{CL}$, et al. Parents' perceptions of adversity introduced by upheaval and uncertainty at the onset of childhood epilepsy. Epilepsia 2001;42:1452-60.

11. Oostrom KJ, Schouten A, Kruitwagen $C L$, et al. Attention deficits are not characteristic of schoolchildren with newly diagnosed idiopathic or cryptogenic epilepsy. Epilepsia 2002;43:301-10.

12. Semah, F. MD; Picot, M.-C. MD; Adam, C. MD; Broglin, D. MD; Arzimanoglou, A. MD; Bazin, B. MD; Cavalcanti, D. MD; Baulac, M. MD. Is the underlying cause of epilepsy a major prognostic factor for recurrence? Neurology 1998;51(5):1256-62.

13. Shinnar $S$ and Pellock JM. Update on the epidemiology and prognosis of pediatric epilepsy. $J$ Child Neurol 2002;17:S4-S17.

14. Sillanpää $M$, Jalava $M$, Kaleva $O$, Shinnar $S$. Long-term prognosis of seizures with onset in childhood. $N$ Engl J Med 1998;338:1715-22.

15. Sillanpää M. Learning disability: occurrence and long-term consequences in childhood-onset epilepsy. Epilepsy Behav. 2004 Dec;5(6):937-44.

16. Stroink $H$, Brouwer $O F$, Arts WF, Geerts $A T$, Peters $A C B$, Van Donselaar $C A$. The first unprovoked, untreated seizure in childhood: a hospital based study of the accuracy of the diagnosis, rate of recurrence, and long term outcome after recurrence. Dutch study of epilepsy in childhood. J Neurol Neurosurg Psychiatry 1998;64:595-600.

17. Verrotti $A$, Morresi $S$, Cutarella $R$, et al. Predictive value of $E E G$ monitoring during drug withdrawal in children with cryptogenic partial epilepsy. Neurophysiol Clin 2000;30:240-5. 
Summary 


\section{Summary}

Children with cryptogenic localization related epilepsy suffer from epileptic seizures for which no cause can be found. The absense of a certain phenomenon is not a solid way to define a cohort. When performing clinical research, cohorts with a stable definition over time are generally preferred. Thus, it is to be expected that not much is known about children with cryptogenic localization related epilepsy.

Hence, for children with cryptogenic localization related epilepsy, the physician cannot tell what is causing the epilepsy, neither what is to be expected from the future.

These questions regarding the future, the prognosis of cryptogenic localization related epilepsy in childhood, involve several outcome measures. Firstly, we were interested in the seizure frequency. Secondly, the neurological and neuropsychological functioning were considered, as epilepsy has been recognized to influence their development. These can be described using three main measures: the motor function, the $I Q$ of the child, and the school results.

In Chapter One a review of existing literature was described.

To perform such a review, cryptogenic localization related epilepsy (CLRE) needed to be defined. We defined CLRE as follows: the condition in which epileptic seizures of a localized onset occur, for which no etiology can be found when an MRI is obtained or the medical history is assessed. Furthermore children with mental retardation were excluded of the cohort, as well as children in whom no neuroimaging was performed. Still, even with such a strict definition, a cohort of children with CLRE today will differ from a cohort in the past or the future. As soon as a cause for epilepsy is recognized which was not known before, children meeting the criteria will no longer be part of the CLRE cohort.

After applying these criteria, few studies were left to review. From these studies, we can firstly conclude that in only a minority of children with CLRE, the epilepsy has a benign course. In other words, most children not easily become seizure free or stay seizure free. More specifically, a wave-like pattern of remission and relapse is described, being typical for CLRE.

Furthermore, withdrawal of the anti-epileptic drugs after long-term remission, often leads to seizure relapse. Reintroduction of medication does not always result in renewed remission.

As for the neuropsychological outcome, children with CLRE have a higher risk for cognitive and behavioural difficulties, regardless of seizure control. The delays in school achievement are found to be severe.

In Chapter Two, a cohort of children with CLRE is compared with two cohorts of children with either symptomatic localization related epilepsy or idiopathic generalized epilepsy. The comparison includes several characteristics of the epilepsy, in an effort to validate the separate classification of CLRE amongst childhood epilepsies. Our study implies that such a separate classification is acceptable. 
In Chapter Three, we describe our CLRE cohort as it was present at Kempenhaeghe Epilepsy Center. Subsequently, we analysed the characteristics of the epilepsy. The only factor found to be significantly related to the outcome appeared to be having more than one seizure type.

Chapter Four is a follow up study, for which we retested part of the original group of children. Besides describing the clinical state of the child regarding the epilepsy and school achievements at this measuring point, we studied the relation between the characteristics of the epilepsy and the outcome over time. In our cohort seizure frequency improved between the two measuring points. Furthermore, children who had already been treated for a longer period at the first measuring point appeared to do better at the second measuring point. This suggests it takes time to control seizures in CLRE.

Regardless of the short follow up, the IQ seemed to improve over time in our cohort. Further research is needed to confirm whether educational achievements will improve as well.

Chapter Five further elaborates on motor function in children with CLRE. Compared to children who were admitted to our epilepsy center but were not diagnosed with epilepsy, children with CLRE were not at significantly higher risk for motor function problems. However, motor problems were found in $35 \%$ of our children, where in the general population this would be $5 \%$. Furthermore, children with CLRE were at higher risk for learning disabilities, which was not correlated to characteristics of the epilepsy, nor to the motor function.

In Chapter Six, our findings of the previous chapters are discussed as a whole, and compared to current literature. Also, the relevance for daily practice is discussed, and we stress the need to carefully consider the aim of the treatment. As no correlation between behavioral outcome (motor function and educational achievements) and seizure frequency has been shown, the side-effects of anti-epileptic drugs regarding the development of the child should be taken into account when persuing seizure freedom.

Paradoxical, when seizure freedom is reached, one should not be to eager to withdraw treatment, as relapse often occurs.

As knowledge regarding the prognosis of CLRE in childhood increases, it becomes more obvious that monitoring closely using a broad approach when counseling these children and their parents is needed. Outcome in epilepsy comprises more than control of seizures. 
Samenvatting 


\section{Samenvatting}

Kinderen met cryptogene lokalisatie gebonden epilepsie hebben epileptische aanvallen waar geen structurele oorzaak voor gevonden kan worden. De afwezigheid van een bepaald fenomeen is echter geen valide wijze om een cohort te definiëren. Daarom is het te verwachten dat er niet veel bekend is over kinderen met cryptogene lokalisatie gebonden epiepsie.

Dientengevolge kan de dokter bij kinderen met cryptogene lokalisatie gebonden epilepsie niet vertellen wat de oorzaak van de epilepsie is, en ook niet wat er van de toekomst verwacht kan worden.

Deze vragen over de toekomst, de prognose van cryptogene lokalisatie gebonden epilepsie in de kindertijd, hebben betrekking op meerdere uitkomstmaten. Allereerst waren we geïnteresseerd in de aanvalsfrequentie. Ten tweede keken we naar het neurologisch en neuropsychologisch functioneren, aangezien bekend geacht kan worden dat epilepsie een invloed heeft op de ontwikkeling hiervan. Deze kan beschreven worden met drie uitkomstmaten: de motorische functie, het $I Q$ van het kind en de resultaten op school.

In Hoofdstuk Eén wordt een review van bestaande literatuur beschreven.

Om een dergelijk review uit te voeren moest cryptogene lokalisatie gebonden epilepsie (CLRE) gedefinieerd worden. Wij definieerden CLRE als volgt: de aandoening waarbij epileptische aanvallen met een gelokaliseerd begin voorkomen, waarvoor geen etiologie gevonden kan worden als een MRI wordt gemaakt, of als de medische geschiedenis beschouwd wordt. Daarnaast werden kinderen met mentale retardatie geëxcludeerd, alsook de kinderen bij wie geen neuro-imaging gebeurd was.

Zelfs met zo'n strenge definitie zal een cohort met kinderen met CLRE van vandaag verschillen van een cohort in het verleden of de toekomst. Zo gauw een nieuwe oorzaak voor epilepsie herkend wordt, zullen kinderen die voldoen aan de criteria niet langer onderdeel zijn van het CLRE cohort.

Nadat we onze criteria hadden toegepast resteerden nog enkele studies. Uit deze studies kunnen we allereerst concluderen dat bij slechts een minderheid van de kinderen met CLRE de epilepsie een goedaardig beloop heeft. Met andere woorden: de meeste kinderen worden niet makkelijk aanvalsvrij, of blijven dit niet.

Verder, stoppen van de medicatie nadat langdurige remissie bereikt is, leidt vaak tot aanvalsrecidief. Opnieuw introduceren van de anti-epileptica heeft dan niet altijd hernieuwde remissie tot gevolg.

Wat betreft de neuropsychologische uitkomst hebben kinderen met CLRE een groter risico op cognitieve en gedragsmatige moeilijkheden, ongeacht de bereikte controle over de aanvalsfrequentie. De achterstand op school is ernstig.

In Hoofdstuk Twee wordt een cohort kinderen met CLRE vergeleken met twee cohorten kinderen met ofwel symptomatische lokalisatie gebonden epilepsie, ofwel idiopathisch gegeneraliseerde epilepsie. De vergelijking betreft verschillende karakteristie- 
ken van de epilepsie, met de bedoeling de afzonderlijke klassificatie van CLRE binnen de epilepsieën van de kindertijd te valideren.

In Hoofdstuk Drie beschrijven we ons CLRE cohort, zoals het zich presenteert in Kempenhaeghe. Vervolgens analyseren we de karakteristieken van de epilepsie. De enige factor waarvan gevonden wordt dat er een significante relatie tot de uitkomst bestaat, was het hebben van meer dan een aanvalstype.

Hoofdstuk Vier is een follow-up studie, waarvoor we een deel van de originele groep opnieuw getest hebben. Naast het beschrijven van de klinische toestand van het kind wat betreft de epilepsie en de schoolresultaten op dit moment, bestudeerden we de relatie tussen de karakteristieken van de epilepsie en de uitkomst in het verloop van de tijd. In ons cohort nam de aanvalsfrequentie af tussen de twee meetpunten. De kinderen die op het eerste meetmoment al langer behandeld werden, hadden een lagere aanvalsfrequentie op het tweede moment. Dit suggereert dat het tijd kost om aanvallen onder controle te krijgen bij CLRE.

Ondanks de korte follow-up, leek het $I Q$ te verbeteren na verloop van tijd in ons cohort. Er is meer onderzoek nodig om te bevestigen of ook schoolresultaten zullen verbeteren.

Hoofdstuk Vijf gaat verder in op de motorische functie van kinderen met CLRE. Vergeleken met kinderen die in ons epilepsie centrum waren opgenomen maar bij wie de diagnose epilepsie niet kon worden gesteld, hadden kinderen met CLRE geen significant hoger risico op motor functie problemen. Er werden echter motorische functie problemen gevonden bij 35\% van de kinderen met CLRE, terwijl dit in de algemene populatie 5\% zou zijn. Daarbij hadden kinderen met CLRE een groter risico op leerproblemen, wat niet gecorreleerd was met epilepsiekarakteristieken, en ook niet met de motorische functie problemen.

In Hoofdstuk Zes worden onze bevindingen uit de eerdere hoofdstukken besproken als een geheel, en vergeleken met de huidige literatuur. Ook wordt de relevantie voor de dagelijkse praktijk besproken, en benadrukken we de noodzaak om zorgvuldig het doel van de behandeling te bepalen. Aangezien er geen correlatie tussen gedragsmatige uitkomst (motorische functie en schoolresultaten) en aanvalsfrequentie aangetoond is, moeten de bijwerkingen van anti-epileptica op de ontwikkeling van het kind meegenomen worden in de pogingen het kind aanvalsvrij te krijgen.

Evident paradoxaal, als aanvalsvrijheid bereikt is, moet men niet te snel de behandeling wegnemen, aangezien terugval regelmatig voorkomt.

Terwijl kennis aangaande de prognose van CLRE in de kindertijd toeneemt, wordt het duidelijker dat intensief volgen met een brede aanpak nodig is bij het counselen van kinderen en hun ouders. Uitkomst van epilepsie behelst meer dan het onder controle hebben van aanvallen. 


\section{Persoonlijke noot}

Het schrijven van deze persoonlijke noot, is grotendeels een dankwoord. Het is het moment dat ik terugkijk op de afgelopen jaren. Het sluit een periode af, de tijd waarin ik dit onderzoek deed en beschreef. Het verdedigen ervan lijkt heel groots, maar het is maar een dag, een moment, een uur. Een mijlpaal, maar geen eindpunt.

Toch is het goed even stil te staan bij hoe ik hier kwam. Dat is toch niet zomaar gebeurd, en dat doet geen enkele promovendus alleen. Veel mensen hebben met hun opmerkingen, vragen en complimenten ervoor gezorgd dat het niet in me opkwam te stoppen.

Dat ik minstens evenveel bladzijden besteed aan al die mensen, als ik nodig heb om mijn werk samen te vatten, vind ik dan ook meer dan terecht.

Most likely, it all started started in 1999, with the elective pediatric neurology program I attended at Turku University, Finland. The enthusiasm of professor Matti Sillanpää made me curious for scientific research. His personal approach in mentorship showed me that asking questions is the basis for knowledge, and that it can be fun and satisfying to bring this to a higher level. It brings me great joy to have you here in Maastricht, professor, dear Matti, on this day.

Daarna was het Marc de Krom die mijn wens om mijn geneeskunde opleiding te verdiepen met onderzoekservaring, niet was vergeten. Marc, dank voor je snelle acties om mij aan de gang te krijgen in de wereld van het promotie-onderzoek. Jammer dat het niet lukte om onze grootse plannen uit te voeren, maar zo lijkt het er toch een beetje op.

Biene, als ik het goed begrijp heb ik het aan jou te danken dat ik dit specifieke onderzoek überhaupt mocht doen. Dat heb je, gezien de voor mij onverwachte wending in mijn werkpad, die toch zo heerlijk past op dit proefschrift, goed ingeschat. 
Beste Bert, ik heb veel geleerd van het AlO zijn bij jou. Meer dan ik had kunnen bedenken voor ik er aan begon. We hebben gelachen, en het was zwaar. Er is geen spijt, wel trots.

Mariette en Johan, vandaag zijn jullie officieel verdeeld tussen mij en Saskia, maar zo zie ik het niet. Johan, met een kritische houding gunde je me het recht op mijn eigen gezicht te gaan. Je leerde me zelf kiezen, risico's nemen en gaf me daarmee wat ik in ieder geval zocht in een aio-traject.

Mariette, jouw praktische tips bij het schrijven en werken als onderzoeker, maar zeker ook het kijkje in de epilepsie-neurologie van alledag waren onmisbaar voor mij als dokter zonder dokter-ervaring.

Professor Renier, mijn prof op afstand. Maar inhoudelijk en als het er op aankwam zo makkelijk dichtbij. Ook de ontmoetingen op de promovendi-dagen deden me goed. Dank u!

In die roerige jaren gingen veel beginnende onderzoekers om me heen eenzelfde rivier af. Saskia, met jou deelde ik de boot bijna letterlijk. We stapten er samen in, in februari 2004. We hebben gezocht naar onze gelijkenissen, we hebben geleerd van onze verschillen. I $\mathrm{k}$ vond het fijn dat we meer dan werk alleen deelden. Dat we het vandaag samen afsluiten, zegt ook genoeg. Het waren goeie jaren!

Saskia bleef toch een beetje 'mijn nieuwe Jaap'. Jaap, ik had graag langer met je gewerkt, ik kon veel van je leren. Ach, wat een onzin, ik heb nog langer met je gewerkt en nog veel lol met je gehad! Onze trip naar Singapore was great, ik vrees dat ik onder dokters niet nog een nieuwe Jaap zal vinden. Ik vind het jammer dat je straks niet mee kunt proosten en dansen, wie weet doen we het volgende zomer over in NY.

Sanne, Max. Sanne en Max. Waar zou ik zijn geweest als ik niet keer op keer terug kon komen bij jullie? We zijn drie verschillende mensen, en wat raakten we goed. Mijn frustraties werden herkend, erkend, waarna ik met een chocotoff of drie weer terug kon aan het werk.

Dave, Vera, Vincent, Marianne, Quido, Nils, Robert, Robbert-Jan, Walter, Eline en Gerrit, jullie maakten mijn tijd in het azM tot wat ie was, inclusief de verhuizingen van achterkamers naar de dungeons bij MRI3. Marielle, ik vond het veel leuker dan ik had verwacht, toen bleek dat mijn onderzoek alsnog zou worden opgepakt. Dank je dat je me daar nog zo bij hebt betrokken.

Lotty, Tamara, Andrei, de mede-Kleine-Aa bewoners. Kempenhaeghe pioniers zijn we met z'n allen. We zagen kansen en probeerden ze te grijpen, en gelukkig hadden we vooral ook veel lol. 
Binnen Kempenhaeghe zijn er nog heel wat mensen die niet mogen worden overgeslagen. Marian Majoie en Gerard van Erp met goede vragen en onderzoekservaring, en typische motiverende complimenten. Frans Hakvoort, voor de blik in de schoolse praktijk, daar waar het allemaal om te doen is. Ankie, Hettie en Caroline voor de persoonlijke interesse en het weten hoe het achter de schermen werkt. Martin Hofman voor het laten zien van de grens. De hele Gedragswetenschappelijke Dienst, waar ik stiekem toch meer bij hoorde dan bij O\&O. Ook aan de mensen van de KNF mijn hartelijke dank voor de leermogelijkheden. De fysiotherapeuten, voor de prettige samenwerking en het geduld. Joost is bij ons thuis "die meneer is er weer!" De uren in de auto heen en terug naar Heeze waren leerzaam, er bleef altijd veel te denken over.

Dit onderzoek had uiteraard niet kunnen plaatsvinden zonder een delegatie uit de doelgroep: aan alle kinderen en ouders een flinke dankjewel!

Mijn ouders, Piet en Marja. Jullie hebben voor de basis gezorgd. Mij zo laten groot worden, dat ik denk dat ik kan wat ik wil.

Renée, lieve peet, en lieve Nina, ik heb er alle vertrouwen in dat jullie ook zo groot worden, wellicht snellen jullie me in de komende jaren voorbij. En dat zal fijn zijn! Aan jullie, en natuurlijk mijn peet Beatrix, dank voor de onvoorwaardelijke interesse, ook in de moeilijke jaren van het afscheid van Harry. Het gemis blijft. Ik kan er lang over dromen wat hij voor zacht trots maar droge opmerking zou hebben over vandaag. En dat paard... dat zal nog wel op zich laten wachten.

Luuk, dit was een van mijn uitdagingen. Jij weet als geen ander hoe een uitdaging bevochten én omarmd kan worden. En ik vind het geweldig voor je dat je nu ver weg bent, maar had je toch graag straks gezien. Mijn kleine broertje, een kus van je zus.

De Augustusmoeders! Lieve Anne, Greet, Rian, Jet, Mick, Ted, Mniek, Jes, Peet, Cin, en Tess. Een dagelijks en nachtelijk oor, geduldig en met humor. Jullie leefden met mijn promotieperikelen net zo hard mee als met de opgroeistunts van ons Augustusgrut. En dat zullen we blijven doen, ze zijn pas 7. Tess, het was een meisjesdroom om een vriendin in de straat te hebben. En het is heerlijk.

Fenne, de timing is perfect, al had ik graag gehad dat je me voor was geweest. De schrik van je eerste aanval staat me nog goed bij, de dag voor ik werd gevraagd over te stappen naar dit onderzoek. Mijn uitdagingen zijn niets vergeleken met waar jij doorheen moest. Dat er eindelijk wat lijkt te zijn gevonden om je prachtbrein wat in toom te houden, is reden voor een feestje. Gelukkig zijn we allebei vrolijk gebleven, en kunnen we straks samen dansen.

Erik en Jonneke, de onvoorwaardelijkheid waarmee jullie naast mij stonden, vooral in de moeilijke momenten, was heerlijk. In de mooie tijd die voor jullie ligt, hoop ik dat ik jullie ook zo goed kan aanvoelen, al zit er een oceaan tussen nu. 
Mijn paranimfen, jullie staan naast mij vandaag: Katja en Christel. Niet voor niks heb ik jullie gevraagd. Marieke, jij staat reserve, ik ging er simpelweg niet vanuit dat je zomaar hier zou zijn. Echt een kadootje dat dat wel zo is, en ik hoop dat we een kadootje terug kunnen geven als feestgangers straks.

Christel, je bent een onbeschrijflijk bijzondere vriendin. Een eigenwijze houding waar zelfs Meis wat van kan leren, dus als peettante goed gekozen. Katja, we hebben grootse plannen, dit is de eerste acte.

Maaike en Pallieter, Martin, Remco, Ewout en Irene, Judith en Jan. Zo'n weekend als het dertigersweekend, dat moet gewoon ieder jaar!

Allerliefste Meis, jij houdt mij dagelijks voor hoe je het leven moet onderzoeken. Geen waarschuwing of ouderlijk verbod dat niet door jou als discutabele stelling wordt opgevat. Je bent een geweldig kind, ik hou van je!

Allerliefste Senne, soms zijn wij de enigen die snappen waar we over praten, en dat vind ik heerlijk. Ik hoop dat dat nog lang zo blijft, ook als je straks-als-je-twintig-bent niet zo vaak meer bij me bent. Ik hou van die momenten, ik hou van jou.

Allerliefste Michiel, mijn schat. Ook al weet ik niet waarom, jij bent het helemaal. Als het einde zoek is, stuur je me terug naar het begin. Het begin is ons thuis.

Ik hou van je. 


\section{Curriculum Vitae}

Rianne Petra Reijs was born on August $31^{\text {st }}, 1976$ in Boxmeer, The Netherlands. She grew up in a smalltown community (Beers), and graduated from WWO at the Merletcollege in Cuijk in 1994. After one year of medical studies in Leuven, Belgium, she moved to Maastricht, where she became a Medical Doctor in 2002. In 1999 she visited Finland for an elective program on pediatric neurology, at the department of Pediatric Neurology of professor Matti Sillanpää. During her internships most of Rianne's electives involved clinical genetics, at the department of Clinical Genetics with dr. Christine de Die-Smulders and professor dr. Connie Schrander-Stumpel.

In 2002 she started research in the field of anti-epileptic drugs and their side-effects, under the guidance of dr. Marc de Krom and professor dr. Bert Aldenkamp, at the department of Neurology of the university hospital in Maastricht. In 2004 she changed topic and started the studies described in this thesis.

Having finished the main work involving these studies, Rianne started working as a youth physician at the GGD (Public Health Services) in 2007. Recently, she started the training towards specialisation in this field of work.

Rianne lives in Maastricht with her family: Michiel, their son Senne (7 years old) and their daughter Meis (5 years old). 


\section{Publications}

Reijs RP, van Mil SG, van Hall MH, Arends JB, Weber JW, Renier WO, Aldenkamp AP. Cryptogenic localization-related epilepsy with childhood onset: The problem of definition and prognosis. Epilepsy Behav. 2006 Jun;8(4):693-702.

Reijs RP, van Mil SG, van Hall MH, Arends JB, Weber JW, Renier WO, Aldenkamp AP. The validity of a separate classification of cryptogenic localization related epilepsy amongst childhood epilepsies. Seizure. $2007 \mathrm{Jul} ; 16(5): 438-44$.

Reijs RP, van Mil SG, Arends JB, van Hall MH, Weber JW, Renier WO, Aldenkamp AP. Cryptogenic localization related epilepsy in children from a tertiary outpatient clinic: is neurological and neuropsychological outcome predictable? Clin Neurol Neurosurg. 2007 Jun;109(5):422-30.

Van Mil SG, Reijs RP, van Hall MH, Aldenkamp AP. The effect of duration of epilepsy on IQ in children with CLRE; a comparison to SLRE and IGE. Seizure. 2008 Jun;17(4):308-13.

Van Mil SG, Reijs RP, van Hall MH, Aldenkamp AP. Neuropsychological profile of children with cryptogenic localization related epilepsy.

Child Neuropsychol. 2008 Jul; 14(4):291-302.

Aldenkamp AP, Arzimanoglou A, Reijs R, Van Mil S. Optimizing therapy of seizures in children and adolescents with ADHD. Neurology. 2006 Dec 26;67(12 Suppl 4):\$49-51.

Aldenkamp AP, Weber B, Overweg-Plandsoen WC, Reijs R, van Mil S.

Educational underachievement in children with epilepsy: a model to predict the effects of epilepsy on educational achievement. J Child Neurol. 2005 Mar;20(3):175-80. 
Reijs R, Aldenkamp AP, De Krom M. Mood effects of antiepileptic drugs. Epilepsy Behav. 2004 Feb;5 Suppl 1:S66-76.

Aldenkamp AP, De Krom M, Reijs R. Newer antiepileptic drugs and cognitive issues. Epilepsia. 2003;44 Suppl 4:21-9.

Vlooswijk MC, Jansen JF, Reijs RP, de Krom MC, Kooi ME, Majoie HJ, Hofman PA, Backes WH, Aldenkamp AP. Cognitive fMRI and neuropsychological assessment in patients with secondarily generalized seizures. Clin Neurol Neurosurg. 2008 Mar 11;

Jansen JF, Aldenkamp AP, Marian Majoie HJ, Reijs RP, de Krom MC, Hofman PA, Eline Kooi M, Nicolay $K$, Backes WH. Functional MRI reveals declined prefrontal cortex activation in patients with epilepsy on topiramate therapy. Epilepsy Behav. 2006 Aug;9(1):181-5. 